\title{
INFORMATION ASYMMETRY, GROUP STRUCTURE AND REPAYMENT: A Study FROM BRAC, SiERRA LEONE
}

November 2014

MSc International Development

Development Economics

Thesis Code: DEC-80436

WAGENINGEN UR
C.E.M. van Zaal

dr. ir. M.J. Voors (Supervisor)

prof. dr. B.W. Lensink (Supervisor) 


\section{ABSTRACT}

By pulling together survey and experimental data, this research provides new empirical insight into the role of information asymmetry in the process of group structure, the role of risk homogeneity under group lending and their implications for repayment using a unique dataset from rural microfinance members of BRAC in Sierra Leone. Using a series of artificial field experiments (AFE) with microfinance members, games were implemented to determine information asymmetries and risk preferences. Evidence shows indirectly that when microfinance members have more social linkages in their group, which is correlated with the pay-out of the coordination game, that their repayment is better. Direct evidence suggest that when small microfinance groups are more homogeneous in risk, repayment of these microfinance members is also better. This also accounts for the homogeneity in small groups in terms of educational level. When members have the same educational level, repayment is better. These outcomes are consistent with several established theories.

Keywords: Information asymmetry, risk homogeneity, repayment behaviour, microfinance, artificial field experiments, BRAC, Sierra Leone, Africa 


\section{INTRODUCTION}

Low income clients in developing countries are often excluded from formal financial markets due to their lack of collateral, lack of (formal) credit history and high risk. However, some financial institutions such as microfinance institutions are trying to provide access for these borrowers through the use of innovative lending schemes, such as joint liability group lending (Van Tassel, 1999). The consensus in the literature is that joint liability group lending mitigates problems of asymmetric information, e.g. moral hazard and adverse selection, by assuming perfect information (Hermes and Lensink, 2007, Giné and Karlan, 2014, Van Tassel, 1999, Stiglitz, 1990, Banerjee et al., 1994, Armendariz de Aghion, 1999, Chowdhury, 2005, Ghatak, 1999, Ghatak, 2000). Especially through positive assortative matching (Guttman, 2008), peer monitoring, peer pressure and access to local information (Godquin, 2004, Armendáriz de Aghion and Morduch, 2010) these asymmetric information problems are being mitigated. The group lending structure is, due to accessibility of local information of microfinance members, expected to be more effective in these activities than microfinance institutions. Social and geographical ties make sure borrowers have better information about eachother (Eijkel et al., 2007) and monitor eachother' actions. The banker's moral hazard problem will be solved and repayment defaults will decrease (Carpenter and Williams, 2010a). Hence, information asymmetry plays a big role in current theories about the (rural) financing world, but it has been proven that it is difficult to analyse and assess the impact of informational frictions and streams within groups (Garmaise and Natividad, 2010). In contrast to the wellestablished stream of theoretical work of information asymmetry (Garmaise and Natividad, 2010), empirical evidence and importance of specific information frictions is relatively thin - in general - and particularly so for (rural) credit markets (Karlan and Zinman, 2009).

Assumed is that when self-selecting groups, if borrowers within a pool have perfect information about each other, borrowing groups will self-select into risk homogeneous groups (Gangopadhyay et al., 2005, Van Tassel, 1999, Wydick, 2001). These risk homogenous groups, have a positive influence on loan repayment (Cassar et al., 2007) and are necessary for welfare improvements under group lending (Berhane et al., 2009). Contrary to these outcomes, microfinance programs in Guatemala and Eritrea have high repayment rates, despite risk heterogeneity among borrowing groups (Sadoulet and Carpenter, 2001, Lensink and Mehrteab, 2003). Armendariz de Aghion and Gollier (2000), Sadoulet (1999) and Guttman (2008) also proclaim that heterogeneity in groups is possible and that homogeneity is not always necessary for welfare improvements under group lending. Discussion concerning the process and design of group composition, hence risk homogeneity and heterogeneity in groups, has evolved (Abbink et al., 2006) since the performance of MFI's differs and it is not clear how these differences in success arise (Berhane et al., 2009). Empirical research is needed to determine whether either homogeneity or heterogeneity in risk holds and which of these can improve welfare (Berhane et al., 2009). Additionally, empirical work testing the relatively importance of group composition for financial behaviour has lagged behind theoretical work on this topic, as also other features of group composition, such as future prospect (Eijkel et al., 2007), can be of any influence to repayment behaviour (Ghatak, 1999).

Efforts to understand precisely how groups are constituted, what role groups play in different contexts and whether and how their role relates to their structure are important for academic interests, for the design of economic and development policies (Attanasio et al., 2014), and for, most importantly, the practicalities of MFIs. If for example heterogeneity in group lending is being observed, improvement in welfare can be enhanced by re-designing their lending mechanisms (Berhane et al., 2009). However, empirical evidence on the process through which group members interact is limited (Marr, 2002, Attanasio et al., 2014, Abbink et al., 2006) and this social process cannot be assumed to be neutral and perfect in regard to impact effects of group lending on repayment of the loans. This paper aims to redress this proces by asking the question: How do information asymmetry and group structure affect repayment behaviour? Key points to assess are first (i) the level of information asymmetry in the small microfinance groups, then (ii) the level of risk homogeneity in the small microfinance groups and lastly (iii) the repayment behaviour of the individual microfinance group 
members. This research provides new empirical insights into the role of information asymmetry in the process of group structure, risk homogeneity under group lending and its implications for repayment using a unique dataset from rural microfinance members in Sierra Leone.

By pulling together survey and experimental data from Sierra Leone, an answer to the question "How doeinformation asymmetry and group structure affect repayment behaviour?" will be given. First, we collected detailed information on members of the microfinance institution BRAC Sierra Leone. We then conducted a series of artificial field experiments (AFE) with the same microfinance members, implementing games to determine information asymmetries and risk preferences. Twenty groups of between five to thirthy women were randomly selected from one of BRAC Sierra Leone's branches. In total 329 women were surveyed. Prior to conducting the research a elaborated pre-analysis plan has been written. This pre-analysis plan can be found on http://clashofinstitutions.com/documents/.

The descriptive statistics suggest considerable variation in information asymmetry and risk preferences among our sample, and therefore variation in risk homogeneity in small loan groups. Another aspect which is noticeable is that repayment of loan is positive in general. Models used to test the relation between risk homogeneity and repayment are estimated using linear regressions.

The evidence suggests that risk homogeneity is robustly positively correlated with repayment, thereby supporting the theoretical models of Ghatak $(1999,2000)$ and van Tassel (1999). Regarding other outcomes of this research, we see that educational homogeneity is positively correlated with repayment, which would imply that when members of a small loan group have the same level of education, repayment would be better. This is in accordance with the theory of Paxton et al. (2000) who shows that if groups are more homogeneous in socio-demographic characteristics, they have less incentives to monitor. Another outcome of our research is that attendance of the meetings have a positive relation with repayment. Thus, when members attend the meetings better, repayment will be better. Additionally, the size of both the small loan groups and big loan groups have a significant relation with repayment. Our results suggest that when small groups increase, repayment will be better. This is conflicting with the theory of Ghatak and Guinnane (1999). And when the big loan group will increase, repayment will be worse. Our final outcome is the outcome of the amount of social links of the microfinance members. Our results imply that when a small loan group has more social linkages between members, repayment would be higher (Godquin, 2004). And even if the pay-out of the coordination game does not have a robust correlation with repayment, it is correlated with the total amount of social linkages. Therefore we can state that when members have more social linkages, their repayment would be better. And, indirectly, when members have more information, repayment would be better, as also has been stated by the theory of Wydick (2001). However, we do not have direct evidence for this.

This paper is organized as follows. In section 2 a theoretical framework is presented. In section 3 we discuss the background of microfinance in Sierra Leone. In section 4 we describe our data and research design and we present our main (experimental) results. In section 5 we aim to interpret the results. Section 6 concludes and presents a elaborated discussion. Tables and instruments used can be found in the appendix. 


\section{THEORETICAL BACKGROUND}

This section entails a conceptual framework and in-depth review of the main concepts used in this paper. In order to present this, literature on four topics has been extensively used. These topics are; joint liability group lending, information asymmetry, group structure and repayment behaviour.

\subsection{GROUP LENDING WITH JOINT LIABILITY}

Group lending is seen as a main innovation responsible for the increase of access to credit for poor households in developing countries (Giné and Karlan, 2014). Currently the majority of microfinance borrowers has access to loans due to group lending programs (Hermes and Lensink, 2007). However, in the last several years microcredit has also been receiving criticism. Microfinance institutions are being accused of making hyper profits of the poor and pushing their clients into debt traps (Banerjee et al., 2013).

The mechanisms of group lending derive from the 'classic' group lending contract established by the Grameen bank. This 'classic' group lending contract does not involve individuals, but groups of customers. Reason for this is because many poor households do not own sufficient physical collateral for a loan (Westover, 2008). Instead of physical collateral, the group lending mechanism makes use of the social ties between clients, e.g. social collateral (Brau and Woller, 2004). The groups are formed voluntary and all members are expected to support the other members when they face difficulties and are jointly accountable for the repayment of the loans; they are jointly liable for each other (Westover, 2008). Group lending with joint liability therefore takes advantage of local information, peer support and peer pressure (Armendáriz de Aghion and Morduch, 2010), and tries to solve information asymmetry problems in the market by assuming that microfinance members have perfect information about each other (Czura, 2012).

Literature on group lending with joint liability has been built from on the literature of the agency theory (Stiglitz and Weiss, 1981, Macedo, 2013). Four channels of information asymmetries and how group lending can improve repayment behaviour, have been identified by (Ghatak and Guinnane, 1999);

1) Adverse selection; microfinance institutions do not interfere in the formation of the groups, therefore the members select their peers themselves (Macedo, 2013), and as a cause they tend self-select in groups with clients of the same type (Van Tassel, 1999).

2) Ex-ante moral hazard; clients have to ensure that the funds will be used properly (Ghatak and Guinnane, 1999, Giné and Karlan, 2014).

3) Monitoring; ensuring that the borrower tells the truth in case of default about her ability to pay (Ghatak and Guinnane, 1999, Carpenter and Williams, 2010b).

4) Ex-post moral hazard; impose sanctions on defaulting group members to repay when they are reluctant to pay (Macedo, 2013, Carpenter and Williams, 2010b).

Group lending combines scale advantages of a formal bank and the mechanisms used in the traditional modes of informal finance (Armendáriz de Aghion and Morduch, 2010). By shifting the responsibility of certain tasks of the lender to the clients, group lending claims to overcome information asymmetries in the rural credit market and can eventually lead to higher repayment (Giné and Karlan, 2014, Presbitero and Rabellotti, 2014, Czura, 2012). However, other authors state the opposite. Besley and Coate (1995) state that borrowers who would repay under individual liability would not do so under group liability. Sadoulet (1997) argues that social collateral used with group liability is not sufficient alone to ensure (high) repayment rates. In the model of Chowdhury (2005) joint liability alone cannot mitigate an ex-ante moral hazard problem. He shows that either sequential lending, where borrowers in a group get their loans sequentially and not at the same time, or monitoring by the lender, makes group lending contracts feasible.

Additionally, a shift in the use of the group lending mechanism has occurred when some pitfalls of group lending with joint liability got known. These pitfalls are firstly the tension caused by group lending. This tension 
can be the threat of punishment, which can harm social capital among members and therefore the existence of safety nets. Second, because a bank is indifferent who is paying back and still gets its money back, a client may decide not to repay their loan. Third, group liability can be costly for safe borrowers as they are often required to repay the loan of their (risky) group members, which can lead to high dropout and difficulty in attracting new clients. Lastly, as time passes and groups mature, clients can diverge in their demand for credit. Loan sizes differ between the group members which can cause tension as clients with smaller loans are required to be a guarantor for clients with a larger loan. Hence, while repayment rates may increase under group liability, the outreach to profitable and credit constrained clients may be smaller due to the pitfalls and therefore the shift in the use of group lending (Giné and Karlan, 2014). Important here is therefore the understanding in the use of the group lending mechanism and characteristics of the members.

\subsection{INFORMATION ASYMMETRY}

The main factors influencing repayment behaviour are related to adverse shocks, low performance of institutions such as justice or education, or to information asymmetries. Information asymmetries can arise when gaining information on the characteristics or behaviour of the borrowers is costly for the microfinance institution (Godquin, 2004). Using the agency theory of Stiglitz (1990) two types of information are of great importance: i) information about the characteristics where one party is not fully aware of the characteristics of another party, such as risky behaviour (adverse selection); ii) and information about intent, where one party is not fully aware of the behavioural intentions of another party, such as using the loan for unproductive purposes (moral hazard). Group lending with joint liability is seen as a method which overcomes these problems due to the assumption that microfinance members have perfect information about each other (Wydick, 2001). Of importance are signals; they can be used to help parties resolve information asymmetry (Moss et al., 2014) and the design and use of appropriate credit schemes, which can restrict the occurrence of information asymmetries (Godquin, 2004).

Several authors have tried to grasp different aspects behind information asymmetry. Some of these models focus on the properties of joint liability lending, such as moral hazard (Banerjee et al., 1994, Chowdhury, 2005, Armendariz de Aghion, 1999) and adverse selection (Ghatak, 1999, Ghatak, 2000, Gangopadhyay et al., 2005). Other models discuss the role of social ties within groups on the repayment behaviour (Besley and Coate, 1995, Wydick, 2001). Cull and Morduch (2007) find that default problems occur with individual lending, but not with group lending. This might mean that the classic models of information asymmetry are of some relevance for individual liability, but that group liability has helped to mitigate the key factor driving the information asymmetry problems. Other authors have focused on the literature on the relationship between institutional environment and its effect on information asymmetries (Antoniou et al., 2008, Booth et al., 2001, DemirgüçKunt and Maksimovic, 1999, Fan et al., 2012, Li and Ferreira, 2011). The main result is that better institutional environments can overcome information asymmetries in (rural) credit markets. In their paper, Karlan and Zinman (2009) test for the presence of distinct types of asymmetric information problems using a field experiment in South Africa. They selected borrowers who face identical rates but different repayment incentives, and borrowers who face different rates but identical repayment incentives. The result of their empirical study is that there is an indication for weak evidence of hidden information and strong evidence of moral hazard. Eijkel et al. (2007) state that due to different future prospects of group members, incentives may differ and therefore information asymmetries between group members can arise. Also Marr (2002) questions the theoretical models of adverse selection and moral hazard which assumme perfect information, because in reality group members do not have perfect information about one another, and/or they cannot raise this information without any costs being made, due to the embeddedness of social, economic and cultural factors.

Information asymmetry plays a big role in current theories about the (rural) financing world, but it has been proven that it is difficult to analyse and assess the impact of informational frictions and streams within groups. Even though theoretical literature is in abundance, there are relatively few natural experiments which show how exactly microfinance helps to overcome information asymmetries and therefore cause a shift in the field 
of information studies (Garmaise and Natividad, 2010). This is partly because of the difficulty of obtaining reliable data on the programs and the behaviour of the participants (Hermes and Lensink, 2007). And as has been stated by Hermes and Lensink (2007) empirical analyses may suffer from endogeneity problems, which can be problematic for studies investigating information asymmetries and repayment rates. Endogeneity problems occur when there is a correlation between the researched causality or relationship with other economic or social characteristics that may independently influence the outcome variable. If this is the case, one cannot draw conclusions on the relationship between the dependent and independent variable (Hermes and Lensink, 2007). In contrast to the well-established stream of theoretical work of information asymmetry (Garmaise and Natividad, 2010), empirical evidence and importance of specific information frictions is relatively thin - in general - and particularly so for (rural) credit markets (Karlan and Zinman, 2009).

In our study, we try to gauge the level of information asymmetries within small microfinance groups. In order to do so, we made use of an artificial field experiment (AFE), e.g. coordination game. With help of the coordination game, and the pay-outs received by the individual microfinance members, we measured the level of information asymmetry within a small group.

\subsection{GROUP STRUCTURE}

Though individual schemes of microfinance institutions differ vastly in their concrete implementations, most microfinance institutions make use of the group lending mechanism (Abbink et al., 2006). This mechanism begins with a lender, such as BRAC, deciding to enter a new location. This lender announces to the residents of this new location that in order to access credit, potential clients must form groups. In the case of BRAC, clients need to form small groups, restricted to the size of five people, but this size varies across programs and regions. Clients obtain the loans and invest them independently. Access to the loans continues until the loan cycle is completed and as long as all loans are repaid. But if any member fails to repay, all group members are denied future credit. In this sense, group members are jointly liable for the loan repayments of their peers (Giné and Karlan, 2014).

Discussion concerning this process of group composition has evolved. Among practitioners as well as academic scholars, there is a heated debate on the appropriate design of their key features (Abbink et al., 2006); especially how groups form themselves and what types of people 'choose' each other. This is also called the process of positive assortative matching. Assortative matching means that if groups are allowed to form themselves, risky and safe borrowers will sort themselves into relatively homogenous groups. Thus safe borrowers will choose to form a group with other safe borrowers and therefore risky borrowers are forced to form a group with other risky borrowers (Guttman, 2008). Studies which stated that homogenous groups in terms of risks are better for repayments, are the models of Ghatak $(1999,2000)$ and van Tassel (1999). Here the result found is that borrowers, if allowed to form their own groups, will sort themselves into relatively homogenous groups of "safe" and "risky" borrowers, which eventually lead to 'positive' assortative matching and higher benefits. The best credit risk groups band together naturally, out of local knowledge of trustworthiness (Armendáriz de Aghion and Morduch, 2010). Any observed risk heterogeneity is due to matching frictions, and not due to the choice of the borrowers. Matching frictions arise when similar risk types are unavailable, or when information asymmetry is present in the process of finding a perfect match (Berhane et al., 2009). Other authors state that risk heterogeneous groups lead to a higher profit, because risky borrowers help safe borrowers and otherwise. Contrary to most theoretical predictions, Sadoulet and Carpenter (2001) and Lensink and Mehrteab (2001) find risk heterogeneity among borrowing groups in Guatemala and Eritrea respectively. Despite the risk heterogeneity, these programs have high repayment rates. Armendariz de Aghion and Gollier (2000), Sadoulet (1999) and Guttman (2008) also state that heterogeneity in groups is possible and that homogeneity is not always necessary for welfare improvements under group lending. However, empirical research is needed to determine whether either homogeneity or heterogeneity in risk holds and which of these can improve welfare (Berhane et al., 2009). And empirical work testing the 
relatively importance of group composition for financial behaviour has lagged behind theoretical work on this topics (Ghatak, 1999).

Next to homogeneity in risk, a group can also be homogeneous in other factors. (Paxton et al. (2000) show that the homogeneity in terms of their ethnicity, occupation, income, etc., of groups in Burkina Faso reduced its repayment behaviour. This may indicate that if group members are more homogeneous in socio-demographic characteristics they have lower incentives to screen, monitor and enforce their peers and may start to collude against the group lending programme (Hermes and Lensink, 2007). A third type of homogeneity can be group homogeneity in terms of interest, economic power, which can be a mean to increase peer monitoring and therefore increase the repayment rate (Stiglitz, 1990).

Still, there are other determinants to be examined. When addressing the literature, some authors show that women tend to self-select themselves into groups with members who have identical status and identical ethnic identities, mitigating possibilities for solidarity (Rankin, 2002). Other studies state that women self-select into groups with members who have significant assets, such as (husbands with) high income, therefore concentrating among those with access to capital and excluding the poorest of the poor (Ackerly, 1997, Fernando, 1997).

Social ties are also expected to increase the repayment performance, as they allow a better efficiency of group dynamics (Godquin, 2004). In a theoretical study, Besley and Coate (1995) show that the possibility of inflicting social sanctions on peers helps improve repayment. This is because social ties facilitate peer monitoring and increase the potential social sanction of peer pressure. And because due to social ties, group members are better informed about each other's activities (Eijkel et al., 2007). However, the effect of social ties is being disputed. In his paper, Wydick (1999) finds no evidence that groups constituted of acquaintances have higher repayment rates than groups consisting of strangers. Social ties may even hamper repayment disciplines as they can lead to more forgivingness toward defaulting group members.

Next to group homogeneity and social ties, dynamic incentives are also expected to increase the repayment performance (Godquin, 2004). However its importance is acknowledged to a much lesser extent in the literature (Abbink et al., 2006, Marr, 2002). Dynamic incentives are being used as a financial innovation in group lending mechanisms (Godquin, 2004). In general, microfinance institutions aim at constituting a longterm relationship with their microfinance groups. Loans are made subject to whether previous loans have been repaid. These two methods are intended to encourage repayment. Therefore it can be argued that dynamic incentives in the microfinance schemes are just as important as peer pressure between the group members (Abbink et al., 2006), and instead of focussing on group lending suitable dynamic schemes should be sought (Armendáriz de Aghion and Morduch, 2000). Another important feature of a group structure is the size of the microfinance groups. In practice, it is unclear how group size affects repayment behaviour and different organizations use different methods. However, in the academic literature different methods have their advocates. Ghatak and Guinnane (1999) state that smaller groups are to be preferred for their better in-group coordination and reduced level of free riding. On the contrary, Buckley (1997) finds that groups with 10 or more members still can work effectively.

Within the reach of our research, we will focus on group structure in terms of risk homogeneity and the effects of risk homogeneity on repayment behaviour. However, as has been stated in the literature, sociodemographics of microfinance members and the characteristics of a group are also of importance in our analysis, and therefore will also be taken into account.

\subsection{REPAYMENT BEHAVIOUR}

While theoretical models have described the potential of group lending to solve information asymmetries, there has been little empirical evidence to understand if and how group lending actually improves repayment 
rates (Karlan, 2007). The study of Giné and Karlan (2014) compares repayment performance in joint liability and individual liability group loans of a microfinance institution in the Philippines and do not find any significant difference in the repayment performance between joint liability and individual liability groups. This would therefore suggest that not joint liability, but the group structure itself is essential for high repayment rates. From this point of view, we will continue this section.

As described earlier in the previous section, self-selection of group can lead to risk homogeneous groups or risk heterogeneous groups. Many authors have claimed that homogeneous groups will lead to a higher repayment rate (Huppi and Feder, 1990, Ghatak, 1999, Ghatak, 2000, Van Tassel, 1999, Gangopadhyay et al., 2005, Cassar et al., 2007) due to matching of similar risk types and due to the facts that members screen and monitor the other members and enforce repayment, because individuals want to reduce the risk of having to contribute to the repayment of loans of others and because individuals want to ensure access to future loans (Cassar et al., 2007). Other authors state that heterogeneous groups lead to a higher profit (Sadoulet and Carpenter, 2001, Lensink and Mehrteab, 2003), because risky borrowers help safe borrowers and otherwise, and therefore maximize the potential gain of mutual insurance.

The process and nature of group composition is crucial for improved performance of groups not only in terms of homogeneity or heterogeneity, but also in terms of inherent social capital. Social capital can be of great benefit to both lenders and borrowers, due to social integration and linkages. These are important intra- and extra-group relationships which constitute an important source of social capital and this can have considerable influence on group performance (Olomola, 2002). Intra-group relationships, also known as relational social capital, in the form of personal trust between individuals and social homogeneity within groups have a positive effect on borrowing group performance (Cassar et al., 2007). Also the paper of Giné and Karlan (2014) tests whether groups that are more socially connected perform better. He finds that stronger social connections of the group lead to higher repayment and savings. They determine a social network in terms of trust, and conclude that being trustworthy is a personal characteristic that determines ones social networks and also leads to a higher repayment rate. Cassar et al. (2007) find that specific trust between borrowers of a group is more important for their repayment behaviour than trust in the society as a whole. Another view of social networks and their influence on repayment rates comes from Carpenter and Williams (2010b). They state that repayment behaviour may depend on the amount of 'nosey' - prone to monitoring - people in the group. They conclude that the more nosey people - monitoring people - there are in your group, the less likely you are to have troubles repaying your loan.

Extensive - theoretical and empirical - research has been done on repayment behaviour, and it does suggest that literature on the link between social capital and repayment in group loans is important and that more research is needed to learn about the impact of social capital on repayment and growth, and other aspects within this field (Giné and Karlan, 2014).

Our study makes several contributions to the literature. First, with the help of an artificial field experiment, a coordination game, we examine the information asymmetry within groups. Second, it tries to gauge the group structure of the microfinance groups. Meaning the homogeneity or heterogeneity in terms of risk behavior of the groups. These two dynamics of a group will be linked with weekly repayment data ranging from April 2013 to March 2014 of 71 small microfinance groups. 


\section{Microfinance in Sierra LeOne}

Since the end of the civil war in 2002, Sierra Leone has made significant progress in maintaining peace and security, and in rebuilding the economy which was nearly destroyed after the decade long conflict. However, this growth is significantly driven by the extractive industry and is largely non-inclusive and undiversified. As a result, poverty rates are still high, e.g. 53 percent in 2011. However, Sierra Leone's formal business sector is evolving, and Sierra Leone is rated as one of the world's top ten business reformers. The financial sector has expanded during the past five years with strong growth in the number of banking and financial institutions (Perrault et al., 2013). Recent studies of the UNCDF (2009) have indicated that the demand for financial services, especially microfinance credit, has grown; in 2003 the unmet demand for financial services was between 76.000 and 145.000 customers, together accounting for a need of US\$ 20 to 40 million, and in 2008 this unmet demand had grown to US\$239 million, to provide loans for 375.000 households. Nowadays, there are about 40 banks, microfinance institutions and other programs providing some form of financial services in a country with a population of about 6 million people (UNCDF, 2009). However, access to credit is still low, around 10 percent (Cordaid, 2013), especially for the rural poor including small holder farmers and small and medium entrepreneurs (SMEs) (UNCDF, 2009, Perrault et al., 2013).

\subsection{ACCESS TO FORMAL CREDIT}

The number of institutions providing financial services in Sierra Leone has grown significantly. The amount of commercial banks has increased to 14 due to the entry of new banks in the last years. These are particularly Nigerian banks. Several of those commercial banks, such as Ecobank and Union Trust Bank, have started microfinance schemes in competition with microfinance institutions (UNCDF, 2009). However, commercial banks have a limited capacity to assess credit risk, and they have limited collateral information on their creditors, which makes the access to credit for the rural poor difficult (Perrault et al., 2013). Next to the commercial banks, there are also six community banks which are started by the Bank of Sierra Leone. These community banks are intended to primarily serve the rural populations (UNCDF, 2009).

A distinguishing and important characteristic of Sierra Leone's financial sector is its high exclusivity. The financial sector mostly serves the middle class, thence supporting large enterprises and people with guaranteed salaries. The economic activities of commercial banks are primarily focused on short-term treasury bills rather than investing in the long-term business sector (Kamara, 2008).

\subsection{ACCESS TO INFORMAL CREDIT}

In West-Africa, microfinance dates back to the $15^{\text {th }}$ century (Bank, 2006) in the form of rotating savings and credit associations (ROSCAs) or osusu. A second indigenous financial mechanism are the moneylenders. ROSCAs are well-known and serve as mechanisms for people to save for medicines, school fees or bride prices. Moneylenders are also common and play a crucial role in providing microfinance to rural Sierra Leoneans at the informal level (Kamara, 2008).

Next to indigenous financial services, the number of international NGOs and MFIs in the country has also continued to grow. The programs of the international NGOs, such as CRS, CARE, World Vision, Concern, Africare, IFAD, FAO and the World Bank, focus on providing rural finance through informal savings and loan schemes. There are also at least nine independent MFIs in the country, these are; ARD, BRAC, CEDA, Finance Salone, GGEM, Hope Micro, LAPO SL, Luma and SMT. Most of the MFIs have their activities taken place in the urban areas of Sierra Leone (UNCDF, 2009), but others such as BRAC also expanded to the rural areas (Figure 8, to be found in Appendix A). 


\subsection{BRAC}

The principal activity of BRAC is the provision of microfinance services. Founded in 1972 in Bangladesh, BRAC is now one of the largest non-governmental organisations in the global south. BRAC's main focus is on the poor, enabling them to organise community human and material resources to create development opportunities. They do this with a holistic development approach with tools such as microfinance, education, healthcare, legal services and community empowerment (BRAC, 2012).

In Sierra Leone, BRAC is providing microfinance services since 2009. Currently, they have 29 branches throughout Sierra Leone (Figure 8, in Appendix A) and their customers' base was growing with 7 percent between 2011 and 2012 (BRAC, 2012). The core activity of BRAC's microfinance services is the provision of group loans (MF program) and small entrepreneurial loans (SEP program).

The surveys and behavioural games of this study were conducted in one of the branches of BRAC. The study took place from March until May 2014.

\subsubsection{BORROWER ELIGIBILITY}

BRAC has established 29 branches all over Sierra Leone. Each branch has three or four loan officers, who are in charge of 250-300 female borrowers. A branch has a minimum amount of 800 female borrowers. These borrowers live all within a range of four kilometres of the branch (Figure 6, in Appendix A). When a branch is being established, clientele has to be found. The potential female borrowers, who are interested and eligible, form small groups of four to five females and apply for an individual loan, but as a group. Then the loan officer decides if they are eligible for the loan and if they can enter the program.

The eligibility criteria for becoming a member is:

- The member must be a female

- The member must be aged between $18-50$ years

- Only one member from each household is selected

- The member must have lived in the area for 3 - 5 years

- The member most not belong to other MFIs

- Prospects should live within $5 \mathrm{~km}$ from the branch

- The member should be living within the boundary of the village/community

- Member should have a business

\subsubsection{GROUP LENDING SCHEME}

The small groups, which consist of four to five people, are jointly liable. Thus, the group members of a small group are together responsible for the repayment of their loans. The small groups are organised in one big group of 25 to 30 people (Figure 7, to be found in Appendix A). These small groups consist of females which already knew each other before entering the BRAC's group lending program. They have formed the small group and therefore we can assume that certain levels of trust and knowledge already exist within this small group.

When everyone is accepted and the big group is constituted, a committee of five people is chosen by all members of the big group. This committee consists of a president, secretary, treasurer and two executive members. Each original small group also has a president. Every year, the committee is being re-chosen if necessary. But often the president of the big group and the small groups remain the same person throughout the years that the group exists. The president of the big group is often also the president of one of the small groups. And in most cases, the president is one of the oldest members of the big group. Everyone receives a passbook where the amount of the loan, the interest rate and the repayments are being noted. A pass photo of the owner of the passbook is added in the book. Whenever someone loses her passbook, a fine has to be paid. 
Every two weeks two group members receive a loan. This is based on their behaviour, as in defaults of repayment and commitment to the meetings, and on their income performance. The size of the loan differs per member. When a member receives a loan of 20 weeks (five months), the interest rate is 13 percent, when the loan which is received last for 40 weeks (ten months), the interest rate is 25 percent.

When a group member is unable to pay their weekly repayment, consequences will occur. The first time this happens, the other members will pay for the defaulting member. But if it happens frequently, the member will be thrown out of the group and therefore out of the group lending scheme. The loan officer will then choose a new eligible female in the area and this new member will join the small group.

During the weekly meetings, which are held in a place maximum one kilometre from all group members, the repayment of the loan is done and questions can be asked. The president of each small group collects the repayments, and then hands them over to the treasurer and the loan officer of BRAC. When someone is unable to repay their loan, the group members of the small group pay the repayment of that person. Due to this arrangement, peer selection and monitoring over each other's peers is an important aspect of the group.

In most urban group lending schemes, the female borrowers own a shop or are street vendors. They tend not to own their own dwelling, but rent them from landowners. In the rural group lending schemes, borrowers tend to engage more in agricultural occupation, but for the most part women own a shop or are street vendors too. They do own their own land and house, because it is cheaper in the rural areas than it is in the urban areas. 


\section{Research Design, Data ANd Model}

This section sets out the sample frame, the repayments, the survey, the behavioural game and the model used in this research.

\subsection{SAMPLE FRAME}

Our study took place in one of the 29 branches of BRAC Sierra Leone, in a rural town located in the south of Sierra Leone. This rural town is built around one of the main highways of Sierra Leone and can be seen as a key hub. Many of the inhabitants are therefore involved in trading or similar occupations. Other inhabitants are farmers or shop owners. The surveyed branch has a total of 35 microfinance groups, scattered in and around the rural town, but all within a distance of five kilometres of the branch. In total the branch caters to around 800 microfinance clients. We surveyed approximately $\frac{3}{8}$ of the branch.

We conducted a survey and behavioural game in May 2014. To learn about the effects of group structure on repayment behaviour we randomly selected 20 big groups from a set of 35 big microfinance groups of the same branch. These 20 big microfinance groups together consisted of 71 small groups and 329 microfinance borrowers. To make sure we surveyed the entire big group, e.g. each of the group members of the 20 groups, we randomized on the big group level. The size of the big groups ranges from 6 to 22 persons, small group sizes ranges from 2 to 7 members (see Table 1). Every participant had to be a member of BRAC Sierra Leone and our selected branch. The microfinance groups and their assigned loan officers together account for a sample size of 349 people.

Even though we used randomization on the big group level to be sure that all of the members of our sampled big groups were surveyed, and therefore the big groups were 'complete', this turned out to be more difficult than we had thought. We encountered several problems. Firstly, administration was not always up to date, due to the lack of infrastructure and digitalisation of BRAC's records. This resulted in member lists which included members that already left the group, or excluded new members. To solve this problem, all BRAC's member lists were checked with the help of the loan officers, to make sure our participant lists were as recent as possible. Another difficulty was the "luma", a market close to Mile 91, where most of the members, who were shop owners and traders, had to go to on Tuesday and Friday to sell their goods. In order to still conduct the surveys and games with these members, the enumerators had to visit them in the evenings when they returned from the luma. Next to the luma, some of the group members also travelled to the bigger cities, such as Kenema and Freetown, to visit families or to trade their goods. Because they often were gone for several weeks, we could not conduct our survey with them. In the end, we completed 16 of the 20 groups; four groups are therefore not completed.

\subsubsection{ATTRITION}

Our dataset consists of two parts, the data obtained when conducting the survey and the data obtained from the weekly repayment sheets (Figure 1). For the first part of our dataset, which is the survey, we surveyed 329 of the 338 selected microfinance members because 9 of the sampled microfinance member were not present during the time of the survey. They were not present due to several reasons, e.g. due to giving birth, attending a funeral or visiting another city for family or work. Therefore the attrition rate when conducting the survey is 2.7 percent. When analysing the data, some of the variables were missing due to mistakes of enumerators, or because the participant did not want to answer the question. After cleaning the data, 307 microfinance members were left. Therefore the attrition rate during the analysis of the data is 6.7 percent. For the second part of the dataset, the weekly repayment sheet, we collected data from 381 microfinance members. However, 74 of those microfinance members were either not in our sample, because they already left the group, or because we either did not sampled them or because the data of them contained was missing, which together accounted for an attrition rate of 19.42 percent. 


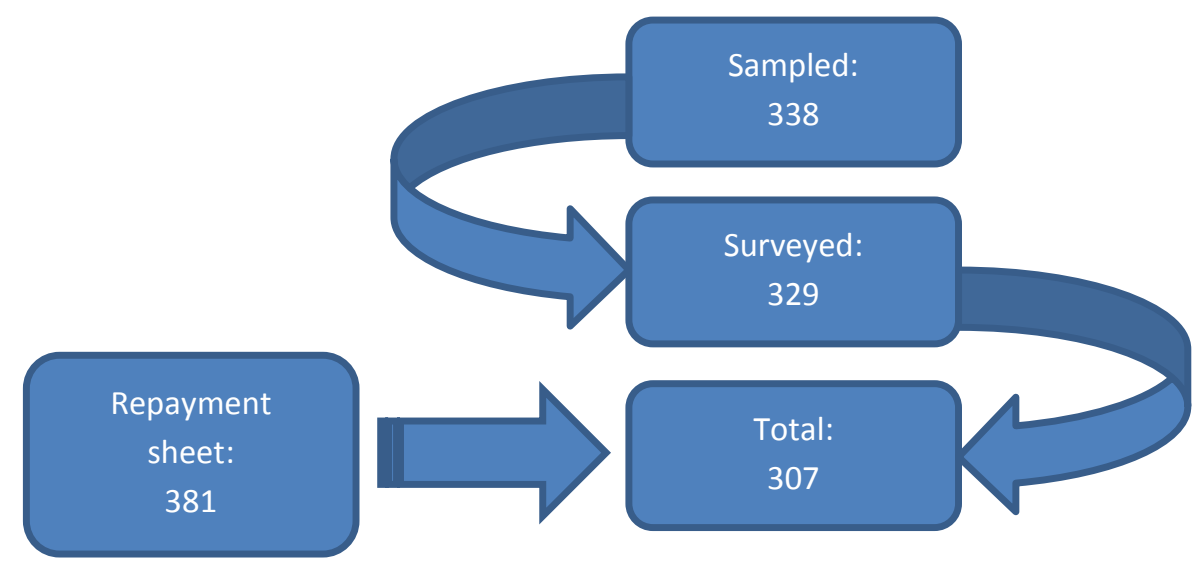

FIGURE 1 ATTRITION

\subsection{REPAYMENT}

To learn about the repayment behaviour of the microfinance members, we used the weekly repayment sheets ${ }^{1}$. On the repayment sheets the group number and the members are depicted. Per member the total amount borrowed, the amount which should be repaid each week and whether they did so or not is noted down. And final, the outstanding amount is also depicted.

In total we collected 52 repayment sheets of March 2013 until March 2014. In doing so, we could examine a long-term behavioural pattern of the microfinance members. Using a dummy for weekly repayment of the loan, where ' 1 ' indicated repayment and ' 0 ' non-repayment, we calculated the repayment behaviour per member over a time period of a year. This is presented in Table 1 . The average repayment over the time period $t=52$, is 0.66 . A continuous dependent variable was made by collapsing the 52 dummy variables into one count variable, which ranges between ' 0 ' (never repaid) and ' 1 ' (always repaid). We see that average repayment is 0.68 , which is equal to 68 percent. Everyone was supposed to repay their weekly amounts, therefore a perfect scenario would indicate that a microfinance member would have a count variable of 1 . In total, 9 out of 307 microfinance members had a count repayment outcome of ' 1 ', which indicates perfect repayment. Reasons for not paying the weekly repayments are not known. There were no microfinance members with a count repayment outcome of ' 0 ', which indicates that they did not repaid anything back.

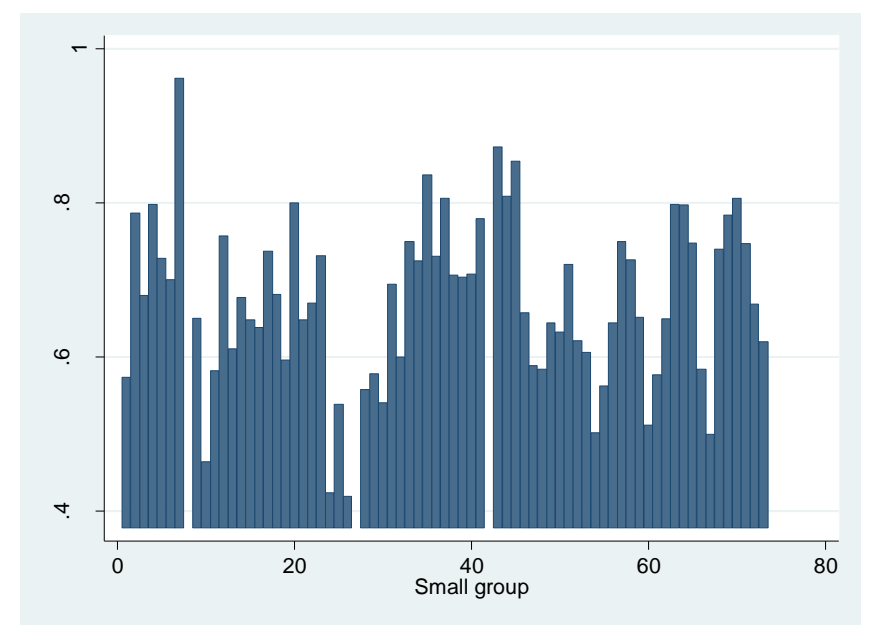

FIGURE 2 REPAYMENT PER SMALL GROUP

\footnotetext{
${ }^{1}$ See Figure 9, Appendix C for example repayment sheet
} 
Table A2 and Figure 2 depict the count repayment variable per small group. Repayment per small groups varies between 0.38 as lowest repayment rate to 0.96 as highest repayment rate. None of the small groups, has a repayment rate of 1 , which would indicate that the entire microfinance loan group repaid all the 52 weekly repayments.

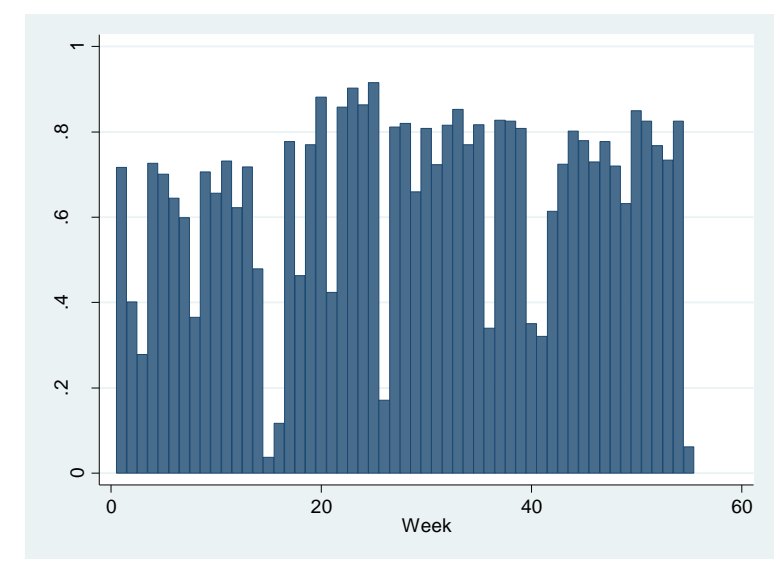

FIGURE 3 REPAYMENT PER WEEK

Table A3 and Figure 3 depict the repayment behavior of the microfinance members per week. With a mean of 0.04 , week 15 has the lowest repayment value. And week 25 has the highest repayment value, with a mean of 0.91 . None of the weeks have a perfect repayment of 1 , where all microfinance members repaid their loan. A clear pattern about this has not been found.

In Figure 4 a histogram of the dependent variable repayment is depicted. Here we see that the dependent variable is slightly skewed to the left side, but we can assume a normal distribution.

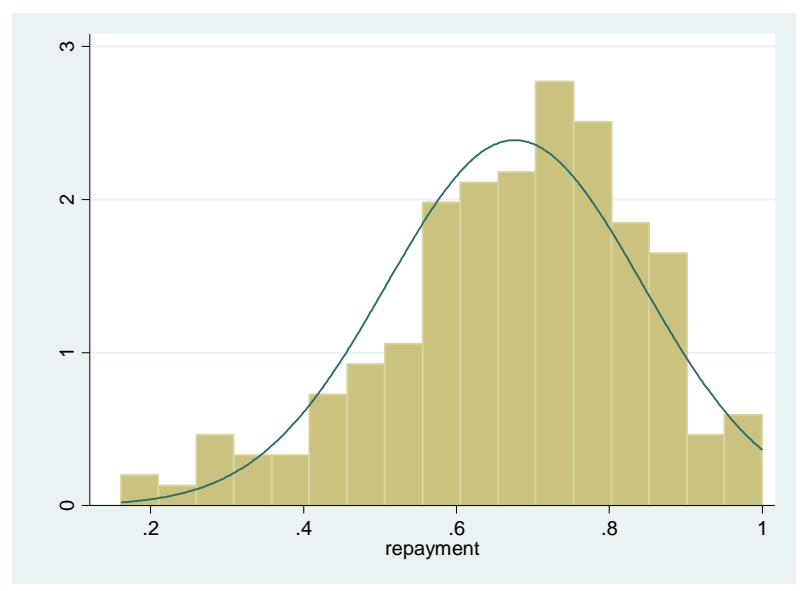

FIGURE 4 NORMAL DISTRIBUTION REPAYMENT

\subsection{SURVEY AND GAMES}

We conducted our survey and behavioural games with all the participants ${ }^{2}$, with the help of 21 enumerators. The enumerators were Sierra Leoneans, with experience in conducting research. They were female and male, and ages were ranging between 22 and 40 . The enumerators were extensively trained and a pilot study was done to ensure that all the enumerators understood the survey and behavioural games and were able to conduct them themselves. The enumerators were supervised by two field supervisors and one research coordinator. When conducting the survey and games, BRAC informed the village chief and the group leader of

\footnotetext{
${ }^{2}$ To implement the survey and behavioural games we made use of extensive protocols, which can be found in Appendix D.
} 
all selected groups of our upcoming visit. Enumerators were instructed to conduct the survey with the group members. If a group member was unavailable, a later visit was made to either her working place or house to make sure the survey was conducted. The enumerator would obtain an oral and written informed consent prior to conducting the interview and emphasis was made on the fact that the respondent could stop the interview at any time. The survey will be in English, but the enumerators will conduct the survey in either Krio, Mende or Temne, depending on the area where they conduct the survey. A survey will take about 60 minutes to conduct. The behavioural games were implemented right after the survey and lasted about a half an hour. Each session started with a general introduction were participants were told that, based on their decisions, a certain amount of money could be won. Also, a silence fee of 1000 Leones would be paid out if the participants would not communicate with other participants after completing the survey and behavioural games. We made a distinction between two games; namely a coordination game and a risk game ${ }^{3}$.

The first behavioural game was aimed to gauge information coordination in a microfinance group. This coordination game was based on a game called "stag hunt", also known as an "assurance game". A stag hunt game is a game where it is better to cooperate with other players, as this will lead to a higher payoff. The stag hunt game is called stag hunt after a story about hunters who can choose to either hunt a large stag with others, which leads to a large payoff if everyone helps to hunt the stag, or to hunt for rabbit on their own. The stag hunt game is a coordination game because there can be more than one Nash equilibrium, and players would like to find a way to coordinate their choices to win the payoff (Camerer and Fehr, 2002). In our coordination game, participants had to answer four questions about the big group, more precise about which of the group members would be i) the new team leader, ii) is the best dressed, iii) the best singer and iv) always on time for group meetings. However, the participant was not supposed to answer according to her own opinion, but she was supposed to give the answer she would thought most people in the big group would answer. Thus, she had to think which answer would be given by most group members. We choose to play the coordination game with the big group, as the microfinance members will have information on the entire village and from that information on have constituted the small groups. The answer which was given the most was the winning answer and all participants who gave this answer won an amount of 1.500 Leones.

To learn about the risk behaviour of the participants, a risk game was used (based on Voors et al. (2010)). In the risk game, the participants could choose between playing a simple gamble and receiving a specific amount of money with certainty. The participants were presented with six choices, and per choice the participants had to choose between A: receiving an amount of money with certainty ( $y$, that varies between the six choices $\left.{ }^{4}\right)$ and $B$ : participating in a game where they either gain 5.000 Leones with probability 0.5 or gain nothing with probability 0.5 . As the certain payoff $(y)$ in A decreases, the gamble in B becomes more attractive. The point at which a participant switches from the safe to the risky alternative allows us to determine the degree of risk behaviour. To present the probability of the gamble visually ( 0.5 of winning 5.000 Leones, and 0.5 of receiving nothing), a coin was flipped. Here the participants could see that the likelihood of getting head or star ${ }^{5}$ is even as the coin only has two sides.

The survey includes a range of questions capturing socio-demographics, income, housing, health, food security, consumption, client satisfaction and risk behaviour. In addition, a network survey was conducted, asking the microfinance members for example with whom they were family ${ }^{6}$. An descriptive overview of the variables is given in Table 1. The average member is about 36 years old and 49 percent of the members attend any kind of education in her life. The size of the household is on average 9 people in a household, ranging from one to 30 household members. The larger share of the members, namely 77 percent of the respondents, has a position in the community, such as woman's leader or wife of the chief. In terms of entrepreneurial behaviour, 37 percent of the respondent wants to start a new business and 42.5 percent has an outstanding loan with another

\footnotetext{
${ }^{3}$ An example of both games can be found in Appendix D.

${ }^{4}$ See Appendix $D$ for more detailed version of risk game

${ }^{5}$ Instead of tails, 'star' was being used as this is depicted on the Sierra Leonean coin

${ }^{6}$ The questions and definition of the variables can be found in Table A1 in Appendix B.
} 
informal or formal institution. With a mean of 1.56, the majority of the respondent considers their health as good. The variable health ranges between 1 and 3, where 1 indicated 'good' and 3 indicated 'bad' The majority of the respondents is also Temne of tribal background and Muslim as religious background.

The second part of the survey is more oriented towards microfinance history of the microfinance member. Table 1 also present the descriptive statistics on this. Attendance of the weekly meetings is average; only 65.3 percent of the respondent indicated to 'always' attend the weekly meetings. And when asking whether group members of the respondents were ever unable to repay their loan, 14 percent answered that this has happened. The size of the small groups varies between 2 and 7. On average small groups consist of 5 people. Big group sizes vary between 6 and 33, on average a big group consists of 20 people.

\section{TABLE 1 DESCRIPTIVES}

\begin{tabular}{|c|c|c|c|c|c|}
\hline Variable & $\begin{array}{c}\text { Observations } \\
\text { member } \\
\text { level }\end{array}$ & Mean & SD & Min & Max \\
\hline \multicolumn{6}{|l|}{ Dependent variable } \\
\hline Repayment & 307 & 0.68 & 0.17 & 0.161 & 1 \\
\hline Repayment, $\mathrm{t}=52$ & 12277 & 0.66 & 0.47 & 0 & 1 \\
\hline \multicolumn{6}{|l|}{ Member characteristics } \\
\hline Age & 301 & 35.58 & 9.64 & 18 & 65 \\
\hline Household size & 304 & 8.98 & 3.83 & 1 & 30 \\
\hline Education $^{7}$ & 307 & 0.49 & 0.50 & 0 & 1 \\
\hline Position in community ${ }^{8}$ & 307 & 0.77 & 0.42 & 0 & 1 \\
\hline Business plans ${ }^{9}$ & 297 & 0.37 & 0.48 & 0 & 1 \\
\hline Loans $^{10}$ & 300 & 0.42 & 0.49 & 0 & 1 \\
\hline Health & 300 & 1.56 & 0.58 & 1 & 3 \\
\hline Temne $^{11}$ & 307 & 0.84 & 0.36 & 0 & 1 \\
\hline Muslim ${ }^{12}$ & 307 & 0.83 & 0.37 & 0 & 1 \\
\hline Attendance $^{13}$ & 307 & 0.65 & 0.48 & 0 & 1 \\
\hline Member unable to repay ${ }^{14}$ & 285 & 0.14 & 0.35 & 0 & 1 \\
\hline Coordination game pay-out $* 1000$ & 307 & 2.55 & 1.92 & 0 & 6 \\
\hline Risk & 277 & 3.47 & 1.79 & 1 & 7 \\
\hline Total links & 303 & 8.02 & 5.85 & 0 & 42 \\
\hline \multicolumn{6}{|l|}{ Small group characteristics, $n=71$} \\
\hline HHI Risk & 307 & 0.31 & 0.10 & 0.17 & 0.75 \\
\hline HHI Age & 307 & 0.01 & 0.01 & 0 & 0.08 \\
\hline HHI Education & 307 & 0.02 & 0.03 & 0 & 0.2 \\
\hline HHI Temne & 307 & 0.01 & 0.01 & 0 & 0.17 \\
\hline HHI Position & 307 & 0.01 & 0.02 & 0 & 0.1 \\
\hline \multicolumn{6}{|c|}{$\begin{array}{l}71 \text { if respondent attained any type of education, } 0 \text { if otherwise } \\
81 \text { if respondent has any type of position in the community, } 0 \text { if otherwise } \\
91 \text { if respondent has plans for a new business, } 0 \text { if otherwise } \\
{ }^{10} 1 \text { if respondent has any other outstanding loans, } 0 \text { if otherwise } \\
{ }^{11} 1 \text { if respondent is Temne, } 0 \text { if otherwise } \\
{ }^{12} 1 \text { if respondent is Muslim, } 0 \text { if otherwise } \\
{ }^{13} 1 \text { if respondent attends the meetings, } 0 \text { if otherwise } \\
1 \text { if respondent has any group members who were unable to repay, } 0 \text { if otherwise }\end{array}$} \\
\hline
\end{tabular}




\begin{tabular}{|c|c|c|c|c|c|}
\hline HHI Muslim & 307 & 0.01 & 0.01 & 0 & 0.08 \\
\hline HHI Business plans & 307 & 0.03 & 0.11 & 0 & 1 \\
\hline HHI Occupation & 307 & 0.01 & 0.01 & 0 & 0.08 \\
\hline Small group size & 307 & 4.64 & 0.94 & 2 & 7 \\
\hline Coordination game small group total $* 1000$ & 307 & 2.61 & 1.29 & 0 & 6 \\
\hline Total social links small group & 307 & 8.09 & 3.55 & 1.28 & 21.53 \\
\hline \multicolumn{6}{|l|}{ Big group characteristics, $n=20$} \\
\hline Coordination game group total $* 1000$ & 309 & 50.98 & 34.45 & 16.50 & 126 \\
\hline Big group size & 309 & 19.52 & 8.06 & 6 & 33 \\
\hline Existence of group in months & 133 & 35.97 & 21.22 & 0 & 64 \\
\hline
\end{tabular}

The individual risk variable is a count variable where the higher the variable, the more risk taking a microfinance member is. On average the microfinance members were risk neutral, with a mean of 3.46 which is exactly in between the minimum of 1 and the maximum of 7 . One of the main disadvantages of the risk preference game is that some of the respondents can fail to understand the procedure, and most authors typically remove this data from their analysis. Depending on the amount of individuals who make inconsistent choices, this may hinder the usability of the method and can bias the results (Charness et al., 2013). Andersen et al. (2006) states that multiple switching points can also reflect indifference between the choices. in our dataset we have 31 respondents who either fail to understand the risk preference game or who are indifferent between choices. This is 10 percent of the entire survey. With the individual risk variables, the Herfindahl index on a small group level was being calculated. The 31 respondents who do not have a risk outcome get the mean Herfindahl outcome of the small group. Here also counts that ' 0 ' indicated a group to be heterogeneous and ' 1 ' indicated a group to be homogeneous. When interpreting the descriptive statistics, we see that with a mean of 0.31 , the small groups on average tend to be more heterogeneous. However with a minimum of 0.17 and a maximum of 0.75 , this will vary between groups.

Maximum amount what can be won is 6000 Leones and minimum is 0 Leones. On average, microfinance members earned 2.500 Leones. This amount varies between members, as some earned the maximum amount and other did not win anything. Also, total payout per big group has been calculated. On average a group earned 50.980 Leones. But this number varies a lot between the groups, as can also be seen by the standard deviation of 34.450 Leones. The total amount earned per group is also higher for bigger groups, therefore the average amount per member of a group is also calculated. On average, regardless the size of a group, a member earned 2.564 Leones with the coordination game.

\subsection{MODEL}

Next we discuss our empirical strategy, which consists of four models, however all four models include the same main independent variables. This independent variables are $C G_{j}$, which is the variable indicating the total amount earned of a small group $j$ when playing the coordination game, and $H H I_{j}$, which is the variable indicating the level of risk homogeneity in a small group.

We created one dependent repayment variable per individual $i$. By taking the mean of 52 weeks of repayment, where every week is either 1 if member repaid, or 0 if otherwise, the data is collapsed into one continuous dependent variable, which can be read as the percentage repaid by the microfinance member. For the first model, we use $C G_{j}$ as an indication of the amount of information respondents of a small group have of each other and $H H I_{j}$ as a measurement of risk homogeneity in a small group;

$Y_{i}=\delta_{1} C G_{j}+\delta_{2} H H I_{j}+\varepsilon_{i j}$ 
where $Y_{i}$ refers to the repayment behaviour of individual $i$ (where $i=1, \ldots, 307$ ) in small group $j$ (where $j=1$, ...,71) which is part of a big group $k$ (where $k=1, \ldots, 20), C G_{j}$ is the amount earned with the coordination game as an indication of the amount of information in a small group $j$ (where $j=1, \ldots, 71$ ) and $H H I_{j}$ is the Herfindahl index concerning risk heterogeneity of small group $j$ (where $j=1, \ldots, 71$ ) which is part of a big group $k$ (where $k$ $=1, \ldots, 20)$. We use a lineair regresson to estimate the model, while using a dummy variable to control for the big group.

As a next step, we add control variables $\beta^{\prime} x_{i}$, which are on the individual level $i$ to the model;

$Y_{i}=\delta_{1} C G_{j}+\delta_{2} H H I_{j}+\beta_{1}{ }^{\prime} x_{i}+\varepsilon_{i j}$

where $\beta_{1}{ }^{\prime} x_{i}$ refers to a vector of individual control variables. The control variables $\beta_{1}{ }^{\prime} x_{i}$ are on the individual level $i$, such as age, education, position in the community, risk preferences, entrepreneurial behaviour, loan behaviour, tribe, religion, attendance of the meetings, individual pay-out of the coordination game, amount of social 'links' between members and whether other member have even been unable to repay. Here we also use a linear regression, while clustering on the small group level and using a dummy variable to control for the big groups, to establish the effect of $C G_{j}$ and $H H I_{j}$ on $Y_{i}$.

In the third model which we establish, we add control variables $\beta^{\prime} x_{j}$, which are on the small group level $j$ to the model:

$Y_{i}=\delta_{1} C G_{j}+\delta_{2} H H I_{j}+\beta_{2}^{\prime} x_{j}+\varepsilon_{i j}$

where $\beta_{2}{ }^{\prime} x_{i j}$ are on the small group level $j$, such as a $H H I_{j}$ of education, tribe, position in the community, entrepreneurial behaviour, but also the size of the small groups. The $H H I_{j}$ of age, muslim and occupation are being left out due to high collinearity with the other $H H I_{j}$ 's. An overview of these correlations can be found in Table A5 in Appendix B. Here we also use a linear regression, while using a dummy variable to control for the big groups, to establish the effect of $C G_{j}$ and $H H I_{j}$ on $Y_{i}$.

The last model is the model where we add both control variables on the individual level and on the small group level;

$Y_{i}=\delta_{1} C G_{j}+\delta_{2} H H I_{j}+\beta_{1}{ }^{\prime} x_{i}+\beta_{2}{ }^{\prime} x_{i j}+\varepsilon_{i j}$

where $\beta_{1}{ }^{\prime} x_{i}$ refers to a vector of control variables on the individual level $i$, such as age, education, position in the community, risk preferences, entrepreneurial behaviour, loan behaviour, tribe, religion, attendance of the meetings, individual pay-out of the coordination game, amount of social 'links' between members and whether other member have even been unable to repay. Other control variables are $\beta_{2}{ }^{\prime} x_{i j}$, which are on the small group level $j$, such as a $H H I_{j}$ of education, tribe, position in the community, entrepreneurial behaviour, but also the size of the small groups. Again, we do not include the $H H I_{j}$ of age, muslim and occupation due to high collinearity. Here we also use a linear regression, while clustering on the small group level, to establish the effect of $C G_{j}$ and $H H I_{j}$ on $Y_{i}$.

When interpreting the models, we are especially interested in the coefficients $\delta_{1}$ and $\delta_{2}$, which are associated with the two variables indicating information asymmetry and risk homogeneity in the small groups $j$ and with the hypothesis that better information between the borrowers lead to self-selection of risk homogeneous groups, which eventually have a positive influence on loan repayment (Cassar et al., 2007, Wydick, 2001, Ghatak, 1999). Because the risk homogeneity of a group can be influenced by socio-demographic variables such as education and age, and also by the characteristics of a group, such as size, we control for these variables to find the true effect of risk homogeneity in risk on repayment. However, as has been stated in Chapter 2, a group can also be homogenous in other factors. Paxton et al. (2000) found that homogeneity in terms of 
ethnicity, occupation, income, etc., of groups in Burkina Faso reduced repayment behaviour. Social ties are also expected to increase the repayment performance (Godquin, 2004, Besley and Coate, 1995, Eijkel et al., 2007), however the effect of social ties is being disputed as Wydick (1999) finds no evidence that groups constituted of acquaintances have higher repayment rates than groups consisting of strangers. Lastly, also the set-up of the microfinance scheme can have significant influence. Aspects such as the long-term relationship between MFIs and their microfinance groups and repayment of previous loans, are intended to encourage repayment (Abbink et al., 2006, Godquin, 2004). Another important feature is the size of the microfinance groups; Ghatak and Guinnane (1999) advocate for small groups contrary to Buckley (1997) who state that groups with 10 or more members work effectively, however, the influence of group size on repayment is still yet to be determined in practice.

\subsection{INFORMATION ASYMMETRY}

This section explores the level of information asymmetry in a small group between group members. We collected data which can touch upon this, using a coordination game and a network survey ${ }^{15}$. We assume that groups with a high payout have less information asymmetry than groups with a low payout; they can more easily coordinate the right answers in the group and therefore have better information about each other and win more Leones in the coordination game. We expect a correlation between the amount of links a member has with other members and the pay-out that a member receives. We expect this because the more links a member has, the stronger and more interlinked her network is and the better the information will be that she has about other members. We also expect a correlation between the risk homogeneity of a small group and the amount that a small group had earned. This is expected because self-selection of groups, assuming perfect information, leads to risk homogeneous groups (Ghatak, 1999). However, such a correlation does not exist (Table A4, Appendix B). This is very remarkable because we expect the two to influence each other, due to working together. This can change the group itself, but it also reflects how the group is formed.

We will look at the total payment of a group, the average payment per group, the 'strength' of a group member's network in terms of the amount of links with other group members, the group size and the amount of months the respondent is been a group member.

Looking at Table 2 we see that total payout per large loan group varies between 1800 and 126000 Leones. Average payout per member varies between 950 and 5437.5. We also see in Table 1 that the total pay-out of the coordination game of the small loan groups varies a lot. On average, a small loan group earned about 2610 Leones, however this amount varies between earning 0 Leones and 6000 Leones. We take the earlier mentioned assumption into account, which states that a higher pay-out assumes better information about each other and therefore less information asymmetry. In the last section of this chapter we will test whether this assumption, with regards to repayment behavior holds. Regarding social linkages in the small groups, we see in Table 1 and Table 2, that these vary a lot between the small groups. The social linkages variable is constituted with the help of the network survey. Asked was with whom the members were family, friends, business partners, to whom they lend money, with whom they meet outside the meetings and whom they know from the church or the mosque. We did not used any weights, all social linkages were evenly important.

In addition, a Pearson's correlation was run to assess the relationship between the above mentioned variables (Table A4, Appendix B). As an outcome, two correlations have been calculated which are of importance. Firstly, a moderate positive correlation between payout per member and total links of member. Second, a strong positive correlation between total payout of small group and total links of the small group. There is no correlation between the coordination game of the risk homogeneity of the small groups.

\footnotetext{
${ }^{15}$ For a detailed description of the variables, see Table A1 in Appendix B
} 
TABLE 2 PAYOUT, NETWORK, GROUP SIZE AND LENGTH OF MEMBERSHIP

\begin{tabular}{|c|c|c|c|c|c|}
\hline Group & $\begin{array}{c}\text { Total } \\
\text { Payout } \\
\text { of Group }\end{array}$ & $\begin{array}{c}\text { Average } \\
\text { Payout } \\
\text { of Group } \\
\text { per Member }\end{array}$ & $\begin{array}{l}\text { Total of } \\
\text { links }\end{array}$ & Group Size & $\begin{array}{c}\text { Amount of months } \\
\text { Member }\end{array}$ \\
\hline 1 & 43500 & 2718.75 & 12.94 & 17 & 36.37 \\
\hline 2 & 45000 & 4090.90 & 11.73 & 11 & 34.91 \\
\hline 3 & 79500 & 2944.44 & 10.22 & 27 & 23.86 \\
\hline 4 & 27000 & 1928.57 & 8.07 & 14 & 40.83 \\
\hline 5 & 19500 & 2785.71 & 4.57 & 6 & 51.33 \\
\hline 6 & 28500 & 950 & 6.17 & 30 & 30.86 \\
\hline 7 & 100500 & 4369.56 & 6.46 & 24 & 27.94 \\
\hline 8 & 43500 & 5437.5 & 10.5 & 7 & 47.86 \\
\hline 9 & 34500 & 2875 & 8.33 & 12 & 18.82 \\
\hline 10 & 58500 & 2437.5 & 8 & 24 & 20.94 \\
\hline 11 & 16500 & 1833.33 & 5.22 & 9 & 19.33 \\
\hline 12 & 27000 & 2250 & 8.33 & 12 & 31.5 \\
\hline 13 & 18000 & 1000 & 4.5 & 18 & 28.41 \\
\hline 14 & 126000 & 3818.18 & 6.09 & 33 & 26.16 \\
\hline 15 & 18000 & 1636.36 & 9.36 & 11 & 25.11 \\
\hline 16 & 39000 & 2052.63 & 8.17 & 18 & 27.77 \\
\hline 17 & 19500 & 1500 & 7.15 & 13 & 10 \\
\hline 18 & 24000 & 2400 & 9.1 & 10 & 9.18 \\
\hline 19 & 61500 & 3617.65 & 10.53 & 14 & 7.19 \\
\hline 20 & 25500 & 1821.43 & 7.43 & 14 & 12.21 \\
\hline
\end{tabular}

\subsection{RISK HOMOGENEITY}

We look at the risk homogeneity of a small group, using the Herfindahl index. First, risk preferences of the individual microfinance member has been calculated, using the data obtained with the risk game. Participants had to choose seven times between a risky and a safe option, and with each new option the riskiness of the risky option would increase. With this dataset, a count variable has been made which indicates the riskiness of the respondent. The higher the count variable, the more risk taking a microfinance member is. Descriptive statistics of the individual risk preferences are depicted in Table 1. On average the microfinance members were risk neutral, with a mean of 3.47 which is exactly in between the minimum of 1 and the maximum of 7 .

After determining the individual risk preferences, we calculate the risk preference concentration, thus how homogeneous or heterogeneous in risk behavior a group is, of the 71 small loan groups consisting of microfinance members. The empirical strategy to do so follows the method implemented by Guerra et al. (2012) who used an adaption of the Herfindahl-Hirschmann Index (HHI) (Herfindahl, 1950, Hirschman, 1945) to measure ethnic concentration of seven groups of immigrants. Here we measure the concentration of risk behavior, instead of ethnicity. Usually, the Herfindahl-Hirschmann Index (HHI) is used as a measure of industrial concentration, or trade (Guerra et al., 2012).

The $\mathrm{HHI}$ ranges from 0 to 1 , where 0 implies no concentration of risk behavior, in other words heterogeneity in risk behavior. 1 indicates that there is a single risk behavior, hence homogeneity in risk behavior, within the microfinance group. For each microfinance member $i(i=1, \ldots, 307)$ of microfinance group $j(j=1, \ldots, 71)$, we computed the $\mathrm{HHI}$ as: 
$H H I_{j}=\sum_{j=1}^{j} s_{i, j}^{2}$,

where $s_{i, j}$ is the share of microfinance members of the microfinance group $j$ (where $j=1, \ldots, 71$ ) on the active microfinance population.

In Table 1 we see that all outcomes indicating homogeneity in risk vary between 0.17 and 0.75 . These numbers imply that the small groups vary a lot in risk homogeneity and risk heterogeneity. This can also be seen in Figure $5 \mathrm{HHI}$ risk per small loan group.

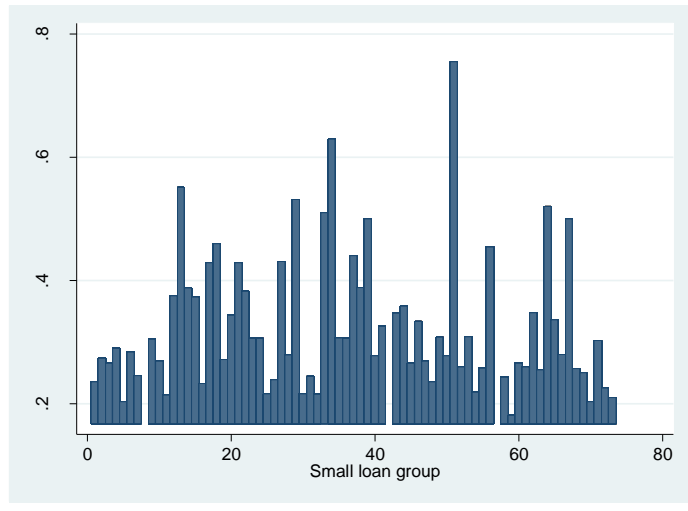

FIGURE 5 HHI RISK PER SMALL LOAN GROUP 


\section{RESULTS}

The descriptive statistics in Table 1 suggest considerable variation in coordination game pay-out amongst the small microfinance groups. This would therefore mean variation in the amount of information that the members of the small group have of each other. There is also variation in risk preferences among our sample, and therefore variation in risk homogeneity in small loan groups. Another aspect which is noticeable is that repayment of loan is positive in general. In this section we investigate whether information asymmetry and risk preferences varies within small groups and we regress these information asymmetries and risk homogeneity of the small groups on the repayment behaviour of the microfinance members. We include several individual, small loan group and big loan group characteristics as controls, and we cluster on the small loan group level to account for intra-group correlation. The primary focus is on the relationship between information asymmetry and repayment, and on the relationship between the group risk homogeneity and individual repayment.

\subsection{INFORMATION ASYMMETRY, RISK HOMOGENEITY AND REPAYMENT}

We present the results on both the relationship between information asymmetry of small microfinance groups on the repayment behaviour of microfinance members, and on the relationship between risk homogeneity of a small microfinance groups on the repayment behaviour of microfinance members, in Table 3. All the regressions in Table 3 use OLS. Across one OLS specification we report a statistically significant and positive relation between the coordination game pay-out and repayment. Here, if pay-out is higher and there information asymmetry is smaller in the small groups, the better the repayment.

Without the inclusion of individual and small loan group controls we can state that there is a positive relation with information within a small group and repayment (column 1). However, our results concerning information asymmetry are not robust to the inclusion of individual and small group controls (column 2 - 4). Therefore we cannot make any statement about the effect of information within a group on the repayment of the microfinance members. Concerning risk homogeneity, our results are robust when including individual and small loan group controls (column 2 and 4). Here repayment has a positive relation with the homogeneity of a small group in risk preferences. In other words, when members of a small group have the same risk preference, the better the repayment.

We do not find evidence in the OLS specifications that any of the socio-demographic controls are significant, and thus have any influence on the repayment. We find evidence that attending the meetings had a positive relation with repayment, hence when attending the meetings better, repayment will be better (column 2 and 4). Next, we employ Herfindahl indices based on tribe, education, position in community and entrepreneurial behaviour as controls (column 3 and 4). We find a positive relation with the Herfindahl index for homogeneity in education. When a small loan group is more homogeneous in education, therefore members in the same group have the same education, repayment will is better. Two other variables regarding the small group are the size of the small loan group and the amount of social links that the members have in the microfinance group. First, the variable measuring the size of the small loan group. Only in the fourth model, this variable shown a positive relation with repayment (column 4). Hence, when a small loan group increases, the repayment will be better. This is in accordance with Buckley (1997), who finds that larger groups of 10 or more members can work efficiently, and in contrast with the theory of Ghatak and Guinnane (1999) who state that smaller groups are preferred due to better in-group coordination and less free-riding. However, we should be careful interpreting this variable due to the fact that our small group only range between 2 or 7 people (Table 1) and we do not know what happens is the groups become bigger than 7 people. Another thing to keep in mind is that the groups might have lost members, this is not taken into account because that data is unknown. However, this variable can therefore also mean what happens when a group loses a member, therefore not only inflicting the variable on the size, but also on the changes which constitute the size. The second variable concern the total of social links members have in the small loan groups. This variable is showing a positive relation with repayment (column 3 and 4). Thus, the more social links the members of a small group have with 
other member, the better the repayment. In the fourth model we also included the variable indicating the size of the big loan group (column 4). Here we see a negative relation between size of the big loan group and repayment. This would mean that the bigger the big loan group, the worsen the repayment.

TABLE 3 INFORMATION ASYMMETRY, RISK HOMOGENEITY AND REPAYMENT

\begin{tabular}{|c|c|c|c|c|}
\hline Dependent variable & $\begin{array}{c}(1) \\
\text { Repayment } \\
\text { OLS }\end{array}$ & $\begin{array}{c}(2) \\
\text { Repayment } \\
\text { OLS }\end{array}$ & $\begin{array}{c}\text { (3) } \\
\text { Repayment } \\
\text { OLS }\end{array}$ & $\begin{array}{c}(4) \\
\text { Repayment } \\
\text { OLS } \\
\end{array}$ \\
\hline \multicolumn{5}{|l|}{ Individual controls } \\
\hline Coordination Game payout & & $\begin{array}{c}0.009 \\
(0.006)\end{array}$ & & $\begin{array}{c}0.009 \\
(0.006)\end{array}$ \\
\hline Risk preference & & $\begin{array}{c}0.002 \\
(0.006)\end{array}$ & & $\begin{array}{c}0.001 \\
(0.006)\end{array}$ \\
\hline Age & & $\begin{array}{l}-0.000 \\
(0.001)\end{array}$ & & $\begin{array}{l}-0.001 \\
(0.001)\end{array}$ \\
\hline Education & & $\begin{array}{c}0.007 \\
(0.022)\end{array}$ & & $\begin{array}{c}0.003 \\
(0.022)\end{array}$ \\
\hline Position in community & & $\begin{array}{c}-0.035 \\
(0.034)\end{array}$ & & $\begin{array}{l}-0.031 \\
(0.037)\end{array}$ \\
\hline Business plans & & $\begin{array}{c}-0.012 \\
(0.021)\end{array}$ & & $\begin{array}{c}-0.016 \\
(0.021)\end{array}$ \\
\hline Other loans & & $\begin{array}{c}0.032 \\
(0.021)\end{array}$ & & $\begin{array}{c}0.028 \\
(0.021)\end{array}$ \\
\hline Temne & & $\begin{array}{l}-0.019 \\
(0.039)\end{array}$ & & $\begin{array}{c}0.002 \\
(0.043)\end{array}$ \\
\hline Muslim & & $\begin{array}{c}0.004 \\
(0.037)\end{array}$ & & $\begin{array}{l}-0.010 \\
(0.038)\end{array}$ \\
\hline Attendance of meetings & & $\begin{array}{l}0.053^{*} \\
(0.027)\end{array}$ & & $\begin{array}{c}0.054 * * \\
(0.025)\end{array}$ \\
\hline Members unable to repay & & $\begin{array}{l}-0.013 \\
(0.026)\end{array}$ & & $\begin{array}{l}-0.009 \\
(0.026)\end{array}$ \\
\hline Total social links & & $\begin{array}{c}-0.001 \\
(0.003)\end{array}$ & & $\begin{array}{c}-0.003 \\
(0.003)\end{array}$ \\
\hline Small group controls & & & & \\
\hline Coordination Game Total Small Group & $\begin{array}{c}0.031 * * \\
(0.012)\end{array}$ & $\begin{array}{c}0.020 \\
(0.013)\end{array}$ & $\begin{array}{c}0.006 \\
(0.014)\end{array}$ & $\begin{array}{c}0.002 \\
(0.012)\end{array}$ \\
\hline HHI Risk & $\begin{array}{c}0.176 \\
(0.107)\end{array}$ & $\begin{array}{c}0.298 * * \\
(0.115)\end{array}$ & $\begin{array}{c}0.201 \\
(0.137)\end{array}$ & $\begin{array}{l}0.262^{*} \\
(0.141)\end{array}$ \\
\hline HHI Temne & & & $\begin{array}{c}0.562 \\
(0.885)\end{array}$ & $\begin{array}{c}1.425 \\
(1.187)\end{array}$ \\
\hline HHI Education & & & $\begin{array}{c}0.272 * * * \\
(0.097)\end{array}$ & $\begin{array}{l}0.252 * \\
(0.128)\end{array}$ \\
\hline $\mathrm{HHI}$ Position in community & & & $\begin{array}{c}0.316 \\
(1.001)\end{array}$ & $\begin{array}{c}0.763 \\
(0.703)\end{array}$ \\
\hline HHI Entrepreneurial behaviour & & & $\begin{array}{c}0.016 \\
(0.104)\end{array}$ & $\begin{array}{c}-0.052 \\
(0.048)\end{array}$ \\
\hline Size of small loan group & & & $\begin{array}{c}0.021 \\
(0.015)\end{array}$ & $\begin{array}{c}0.022 * * \\
(0.011)\end{array}$ \\
\hline Total links small group & & & $\begin{array}{c}0.008 * * \\
(0.003)\end{array}$ & $\begin{array}{l}0.008^{*} \\
(0.004)\end{array}$ \\
\hline Size of big loan group & & & & $\begin{array}{c}-0.007 * * \\
(0.003)\end{array}$ \\
\hline Constant & $\begin{array}{c}0.575^{* * *} \\
(0.057)\end{array}$ & $\begin{array}{c}0.542 * * * \\
(0.099)\end{array}$ & $\begin{array}{c}0.332^{* * *} \\
(0.119)\end{array}$ & $\begin{array}{c}0.468^{* * *} \\
(0.135)\end{array}$ \\
\hline $\begin{array}{l}\text { Observations } \\
R^{2}\end{array}$ & $\begin{array}{c}307 \\
0.261\end{array}$ & $\begin{array}{c}243 \\
0.331\end{array}$ & $\begin{array}{c}307 \\
0.309\end{array}$ & $\begin{array}{c}243 \\
0.376\end{array}$ \\
\hline Big group dummies & y & y & y & $\mathrm{y}$ \\
\hline
\end{tabular}

\subsection{ROBUSTNESS}

In this section we report the outcomes of a series of robustness analyses (Table 4) First, to explore whether the outcomes of the artificial field experiments translate into differences in behaviour in 'real life', we replace our experimental variables with survey-based proxies (column 1 and 2). Second, instead of the count repayment 
variable as dependent variable, we use a dummy as variable (column 3 ). This dummy is based on whether the repayment behaviour of a respondent is above or below the repayment median of 0.5. And lastly, we left out 31 respondents from who the risk preferences unknown is (4).

First, we explore whether the outcomes of the artificial field experiments translate into differences in behaviour in 'real life' as we replace the experimental variables by survey based variables. The experimental variable measuring information asymmetry is replaced by the amount of social links of the members in the small groups (column 1). This proxy is chosen as this is also a variable measuring social inclusion in the small group. When comparing with Table 3, we see that four similar outcomes are being found. First, a positive relation between attendance of meetings and repayment. Second, a positive relation between the Herfindahl index of education and repayment, hence if members have the same level of education repayment will be better. Third, we find a negative relation between the size of big loan groups and repayment. And lastly, we also find a positive relation between the amount of social links in a small group and repayment. The proxy which replaces the experimental variable measuring risk homogeneity, is the standard deviation of risk preference in a small group (column 2). This proxy is measured by taking the standard deviation of risk preferences of small group members. Consistent with Table 3 we find a positive relation between attendance of the meetings. Second, we find a similar outcome of the Herfindahl index of education, namely a positive relation. Third, we find a negative relation between the size of the big groups and repayment. And lastly, we find a positive relation between the amount of social links and repayment, which is consistent with the findings in Table 3. Additionally, using the proxy of the standard deviation of risk preferences in a small group, we also find a positive relation between the Herfindahl index of having a position in the community and repayment. However, this finding is likely correlated with the other Herfindahl indices, as the coefficient seems to be too large.

Second, we estimate the relation between repayment and risk homogeneity with help of a linear regression, using the dependent variable as a dummy variable (where ' 1 ' if respondent count repayment behaviour is above the median of 0.5 and ' 0 ' is otherwise). We estimated the model which is the model estimating the relation between information asymmetry and repayment using the pay-out of the coordination game, and estimating the relation between risk homogeneity and repayment using the Herfindahl index as risk homogeneity measurement. Outcomes of this model differ from the outcomes in Table 3. First, there is a positive relation between the individual coordination game pay-out and repayment. This would mean that when an individual member's pay-out increases, her repayment would be better. Second, we do not find any positive relation between attendance of the meetings and repayment. Missing also is the positive relation between Herfindahl index of education and repayment, hence if members have the same level of education whether this would indicate better repayment. The three outcomes which are consistent with the outcomes in Table 3 are the outcomes concerning the Herfindahl index of risk and the size of the big loan groups and the small loan groups. Here we also find a positive relation between a small group being homogeneous in risk preferences and repayment, and we find a negative relation between the size of big loan groups and repayment. Additionally, using this model, we find a positive relation between the size of small loan groups and repayment. This would mean that if a small loan group increases, repayment would be better.

Lastly, the relation between information asymmetry and repayment and the relation between risk homogeneity and repayment is being estimated using a linear regression without 31 respondents due to missing risk preference variables. We estimated the model using linear regression with the control variables on individual and small group level (column 4). Consistent with the regression in Table 3 which use a dataset including the 31 respondents, we find a positive relation between the risk homogeneity of a small group and repayment. This indicated that the more homogeneous a small group is in risk preferences, the better the repayment. We also find a positive relation between attendance of the meetings and repayment behaviour. A positive relation is also found between homogeneity in education of the small groups and repayment of the microfinance members. We also find that the relation between the size of the big loan groups and the 
repayment behaviour is negative. And lastly, as also is found in Table 3, there is a positive relation between the size of the small loan group and repayment. Additionally, using the proxy of the standard deviation of risk preferences in a small group, we also find a positive relation between the Herfindahl index of having a position in the community and repayment. However, this finding is again likely correlated with the other Herfindahl indices, as the coefficient seems to be too large. With regards to robustness, data seems to have mainly the same correlations, especially with regards to the information asymmetry proxy and risk homogeneity proxy.

TABLE 4 ROBUSTNESS TABLE

\begin{tabular}{|c|c|c|c|c|}
\hline Dependent variable & $\begin{array}{c}\text { (1) } \\
\text { Repayment } \\
\text { OLS } \\
\end{array}$ & $\begin{array}{c}\text { (2) } \\
\text { Repayment } \\
\text { OLS }\end{array}$ & $\begin{array}{c}\text { (3) } \\
\text { Dummy repayment } \\
\text { OLS } \\
\end{array}$ & $\begin{array}{c}(4) \\
\text { Repayment } \\
\text { OLS }\end{array}$ \\
\hline \multicolumn{5}{|l|}{ Individual controls } \\
\hline Coordination Game payout & $\begin{array}{c}0.009 \\
(0.006)\end{array}$ & & $\begin{array}{l}0.025^{*} \\
(0.014)\end{array}$ & $\begin{array}{c}0.007 \\
(0.006)\end{array}$ \\
\hline Risk preference & $\begin{array}{c}0.001 \\
(0.006)\end{array}$ & $\begin{array}{l}-0.000 \\
(0.007)\end{array}$ & $\begin{array}{l}-0.002 \\
(0.015)\end{array}$ & $\begin{array}{c}0.002 \\
(0.007)\end{array}$ \\
\hline Age & $\begin{array}{l}-0.001 \\
(0.001)\end{array}$ & $\begin{array}{l}-0.001 \\
(0.001)\end{array}$ & $\begin{array}{l}-0.002 \\
(0.002)\end{array}$ & $\begin{array}{l}-0.001 \\
(0.001)\end{array}$ \\
\hline Education & $\begin{array}{c}0.001 \\
(0.021)\end{array}$ & $\begin{array}{c}0.000 \\
(0.021)\end{array}$ & $\begin{array}{c}0.007 \\
(0.055)\end{array}$ & $\begin{array}{c}0.004 \\
(0.022)\end{array}$ \\
\hline Position in community & $\begin{array}{l}-0.024 \\
(0.037)\end{array}$ & $\begin{array}{l}-0.019 \\
(0.038)\end{array}$ & $\begin{array}{c}0.038 \\
(0.086)\end{array}$ & $\begin{array}{l}-0.032 \\
(0.037)\end{array}$ \\
\hline Business plans & $\begin{array}{l}-0.017 \\
(0.021)\end{array}$ & $\begin{array}{l}-0.017 \\
(0.021)\end{array}$ & $\begin{array}{l}-0.038 \\
(0.043)\end{array}$ & $\begin{array}{l}-0.020 \\
(0.022)\end{array}$ \\
\hline Other loans & $\begin{array}{c}0.029 \\
(0.021)\end{array}$ & $\begin{array}{c}0.029 \\
(0.022)\end{array}$ & $\begin{array}{c}0.051 \\
(0.047)\end{array}$ & $\begin{array}{c}0.036 \\
(0.022)\end{array}$ \\
\hline Temne & $\begin{array}{c}0.008 \\
(0.043)\end{array}$ & $\begin{array}{c}0.002 \\
(0.042)\end{array}$ & $\begin{array}{c}0.046 \\
(0.090)\end{array}$ & $\begin{array}{c}0.005 \\
(0.043)\end{array}$ \\
\hline Muslim & $\begin{array}{l}-0.018 \\
(0.038)\end{array}$ & $\begin{array}{l}-0.008 \\
(0.038)\end{array}$ & $\begin{array}{c}0.030 \\
(0.093)\end{array}$ & $\begin{array}{c}0.000 \\
(0.041)\end{array}$ \\
\hline Attendance of meetings & $\begin{array}{c}0.050^{* *} \\
(0.025)\end{array}$ & $\begin{array}{l}0.051^{* *} \\
(0.025)\end{array}$ & $\begin{array}{c}0.064 \\
(0.060)\end{array}$ & $\begin{array}{c}0.060^{* *} \\
(0.026)\end{array}$ \\
\hline Members unable to repay & $\begin{array}{l}-0.010 \\
(0.025)\end{array}$ & $\begin{array}{l}-0.008 \\
(0.026)\end{array}$ & $\begin{array}{c}0.015 \\
(0.062)\end{array}$ & $\begin{array}{l}-0.022 \\
(0.027)\end{array}$ \\
\hline Total social links & $\begin{array}{l}-0.003 \\
(0.003)\end{array}$ & $\begin{array}{l}-0.003 \\
(0.003)\end{array}$ & $\begin{array}{l}-0.007 \\
(0.006)\end{array}$ & $\begin{array}{l}-0.003 \\
(0.003)\end{array}$ \\
\hline Small group controls & & & & \\
\hline Coordination Game Total Small Group & & & $\begin{array}{l}-0.013 \\
(0.026)\end{array}$ & $\begin{array}{c}0.001 \\
(0.012)\end{array}$ \\
\hline HHI Risk & & & $\begin{array}{c}0.589^{* *} \\
(0.264)\end{array}$ & $\begin{array}{l}0.307^{*} \\
(0.173)\end{array}$ \\
\hline HHI Education & $\begin{array}{l}0.214^{*} \\
(0.117)\end{array}$ & $\begin{array}{c}0.256^{* *} \\
(0.119)\end{array}$ & $\begin{array}{c}0.024 \\
(0.282)\end{array}$ & $\begin{array}{c}0.287^{* *} \\
(0.138)\end{array}$ \\
\hline HHI Temne & $\begin{array}{c}1.926 \\
(1.207)\end{array}$ & $\begin{array}{c}1.818 \\
(1.151)\end{array}$ & $\begin{array}{c}0.816 \\
(1.707)\end{array}$ & $\begin{array}{c}1.076 \\
(1.174)\end{array}$ \\
\hline HHI Position in community & $\begin{array}{c}0.777 \\
(0.595)\end{array}$ & $\begin{array}{l}1.164^{*} \\
(0.630)\end{array}$ & $\begin{array}{c}1.945 \\
(2.131)\end{array}$ & $\begin{array}{l}1.487^{*} \\
(0.780)\end{array}$ \\
\hline $\mathrm{HHI}$ Entrepreneurial behaviour & $\begin{array}{l}-0.032 \\
(0.045)\end{array}$ & $\begin{array}{l}-0.015 \\
(0.043)\end{array}$ & $\begin{array}{l}-0.024 \\
(0.129)\end{array}$ & $\begin{array}{l}-0.032 \\
(0.045)\end{array}$ \\
\hline Size of small loan group & $\begin{array}{c}0.009 \\
(0.011)\end{array}$ & $\begin{array}{c}0.010 \\
(0.010)\end{array}$ & $\begin{array}{l}0.062^{* *} \\
(0.030)\end{array}$ & $\begin{array}{c}0.029 * * \\
(0.012)\end{array}$ \\
\hline Size of big loan group & $\begin{array}{c}-0.005^{* *} \\
(0.003)\end{array}$ & $\begin{array}{l}-0.005^{*} \\
(0.003)\end{array}$ & $\begin{array}{l}-0.013 * \\
(0.007)\end{array}$ & $\begin{array}{c}-0.007^{* *} \\
(0.003)\end{array}$ \\
\hline Total social links of small group & $\begin{array}{c}0.009 * * \\
(0.004)\end{array}$ & $\begin{array}{c}0.008^{* *} \\
(0.004)\end{array}$ & $\begin{array}{c}0.005 \\
(0.008)\end{array}$ & $\begin{array}{c}0.006 \\
(0.004)\end{array}$ \\
\hline Standard deviation risk preferences & & $\begin{array}{c}0.027 \\
(0.018)\end{array}$ & & \\
\hline Constant & $\begin{array}{c}0.595^{* * *} \\
(0.121) \\
\end{array}$ & $\begin{array}{c}0.548^{* * *} \\
(0.129)\end{array}$ & $\begin{array}{c}0.523 \\
(0.367) \\
\end{array}$ & $\begin{array}{c}0.416 * * * \\
(0.146)\end{array}$ \\
\hline $\begin{array}{l}\text { Observations } \\
R^{2}\end{array}$ & $\begin{array}{c}243 \\
0.368\end{array}$ & $\begin{array}{c}243 \\
0.367\end{array}$ & $\begin{array}{c}243 \\
0.228\end{array}$ & $\begin{array}{c}229 \\
0.366\end{array}$ \\
\hline
\end{tabular}




\section{CONCLUSION}

In this paper we focus on the consensus in the literature, which state that joint liability group lending mitigates asymmetric information problems by assuming perfect information (Hermes and Lensink, 2007, Giné and Karlan, 2014, Van Tassel, 1999, Stiglitz, 1990, Banerjee et al., 1994, Armendariz de Aghion, 1999, Chowdhury, 2005, Ghatak, 1999, Ghatak, 2000). This is done especially due to positive assortative matching, peer monitoring, peer pressure and access to local information. Because microfinance members have access to local information, the responsibility of certain tasks of the lender shifts to the clients. Hereby information asymmetries will be solved and repayment will be higher (Giné and Karlan, 2014, Presbitero and Rabellotti, 2014, Czura, 2012). Next to the fact that joint liability group lending assumes that microfinance members have better information about each other than the lender does, it also assumes that joint liability group lending leads to risk homogenous groups due to positive assortative matching (Guttman, 2008). Studies which stated that homogenous groups in terms of risks are better for repayments, are the models of Ghatak $(1999,2000)$ and van Tassel (1999). Contrary to these theoretical predictions, Sadoulet and Carpenter (2001) and Lensink and Mehrteab (2001) find risk heterogeneity among borrowing groups in Guatemala and Eritrea respectively. Despite the risk heterogeneity, these programs have high repayment rates.

Information asymmetry plays a big role in current theories about the (rural) financing world, but it has been proven that it is difficult to analyse and assess the impact of informational frictions and streams within groups (Garmaise and Natividad, 2010). Discussion concerning the process and design of group composition, hence risk homogeneity in groups, has evolved (Abbink et al., 2006) since the performance of MFI's differs and since it is not clear how these differences in success arise. In contrast to the well-established stream of theoretical work (Garmaise and Natividad, 2010), empirical evidence of specific information frictions and homogeneity in risk is relatively thin - in general - and particularly so for (rural) credit markets (Karlan and Zinman, 2009, Berhane et al., 2009).

By pulling together survey and experimental data from Sierra Leone, this paper aims to answer the question "How does information asymmetry and group structure affect repayment behaviour?". Key points to assess are first (i) the level of information asymmetry in the small microfinance groups, then (ii) the level of risk homogeneity in the small microfinance groups and lastly (iii) the repayment behaviour of the individual microfinance group members. This research provides new empirical insights into the role of information asymmetry in the process of group structure, risk homogeneity under group lending and its implications for repayment using a unique dataset from rural microfinance members in Sierra Leone.

The first remarkable finding of this paper is the fact that we did not find any (positive) correlation between information asymmetry and risk homogeneity. We expect this correlation because self-selection of groups, assuming perfect information, leads to risk homogeneous groups (Ghatak, 1999). However, such a correlation does not exist. This is very remarkable because we expect the two to influence each other, due to the fact that group members are working together. This can change the group itself by influencing the risk preferences of a group, but it also reflects how the group is formed due to the fact that group members have perfect information and therefore self-select into groups with the members who have the same risk preferences.

The evidence suggests that risk homogeneity is robustly positively correlated with repayment, thereby supporting the theoretical models of Ghatak $(1999,2000)$ and van Tassel $(1999)$. Regarding other outcomes of this research, we see that educational homogeneity is positively correlated with repayment, which would imply that when members of a small loan group have the same level of education, repayment would be better. This is in accordance with the theory of Paxton et al. (2000) who shows that if groups are more homogeneous in socio-demographic characteristics, they have less incentives to monitor. Another outcome of our research is that attendance of the meetings have a positive relation with repayment. Thus, when members attend the meetings better, repayment will be better. Additionally, the size of both the small loan groups and big loan groups have a significant relation with repayment. Our results suggest that when small groups increase, 
repayment will be better. This is conflicting with the theory of Ghatak and Guinnane (1999). And when the big loan group will increase, repayment will be worse. Our final outcome is the outcome of the amount of social links of the microfinance members. Our results imply that when a small loan group has more social linkages between members, repayment would be higher (Godquin, 2004). And even if the pay-out of the coordination game does not have a robust correlation with repayment, it is correlated with the total amount of social linkages. Therefore we can state that when members have more social linkages, their repayment would be better. And, indirectly, when members have more information, repayment would be better, as also has been stated by the theory of Wydick (2001). However, we do not have direct evidence for this.

A limitation of this research is the fact that we cannot dissociate between the theory of moral hazard and adverse selection. In order to do so, the research should have been designed differently; either before the constitution of the small loan groups, in order to test the theory of adverse selection, whether members select in homogeneous or heterogeneous groups. Or on a later stage, and in addition monitoring what the microfinance members spend their loan on. In this way, a research can test the theory of moral hazard, which is about if a microfinance members uses their funds properly. Another limitation is the design of our field artificial experiments. When playing our risk game, we did not played the game with an incentive to earn a certain amount of money. Because we did not use such an incentive, one can doubt how realistic the outcomes are. A third limitation is the quality of some of the repayment data. Due to lack of administration of BRAC's rural offices, one can image that mistakes can be made. Often members paid later or through other channels. However, this cannot be monitored. One have to keep in mind that this research cannot be generated over the entire population of Sierra Leone. The microfinance members are carefully selected by the microfinance insitition themselves, and therefore this research already deals with a selection bias. However, besides these limitations, this research contributes to the evidence gathered around the use of joint liability group lending in rural developing countries. 


\section{REFERENCES}

Abbink, K., Irlenbusch, B., \& Renner, E. (2006). Group size and social ties in microfinance institutions. Economic Inquiry, 44(4), 614-628.

Ackerly, B. (1997). What's in a design?: the effects of NGO programme delivery choices on women's empowerment in Bangladesh: na.

Andersen, S., Harrison, G. W., Lau, M. I., \& Rutström, E. E. (2006). Elicitation using multiple price list formats. Experimental Economics, 9(4), 383-405.

Antoniou, A., Guney, Y., \& Paudyal, K. (2008). The determinants of capital structure: capital market-oriented versus bank-oriented institutions. Journal of financial and quantitative analysis, 43(01), 59-92.

Armendariz de Aghion, B. (1999). On the design of a credit agreement with peer monitoring. Journal of Development Economics, 60(1), 79-104.

Armendariz de Aghion, B., \& Gollier, C. (2000). Peer group formation in an adverse selection model. The Economic Journal, 110(465), 632-643.

Armendáriz de Aghion, B., \& Morduch, J. (2000). Microfinance beyond group lending. Economics of Transition, $8(2), 401-420$.

Armendáriz de Aghion, B., \& Morduch, J. (2010). The economics of microfinance: MIT press.

Attanasio, O., Augsburg, B., De Haas, R., Fitzsimons, E., \& Harmgart, H. (2014). Group lending or individual lending? Evidence from a randomised field experiment in Mongolia: Discussion Paper, Wissenschaftszentrum Berlin für Sozialforschung, Abteilung Ökonomik des Wandels: Schwerpunkt Markt und Entscheidung.

Banerjee, A. V., Besley, T., \& Guinnane, T. W. (1994). Thy neighbor's keeper: The design of a credit cooperative with theory and a test. The Quarterly Journal of Economics, 109(2), 491-515.

Banerjee, A. V., Duflo, E., Glennerster, R., \& Kinnan, C. (2013). The miracle of microfinance? Evidence from a randomized evaluation (No. w18950). National Bureau of Economic Research.

Bank, A. D. (2006). Microfinance Policy and Strategy for the Bank Group (O. P. a. R. Department., Trans.).

Berhane, G., Gardebroek, C., \& Moll, H. A. (2009). Risk-matching behavior in microcredit group formation: evidence from northern Ethiopia. Agricultural Economics, 40(4), 409-419.

Besley, T., \& Coate, S. (1995). Group lending, repayment incentives and social collateral. Journal of Development Economics, 46(1), 1-18.

Booth, L., Aivazian, V., Demirguc-Kunt, A., \& Maksimovic, V. (2001). Capital structures in developing countries. The Journal of Finance, 56(1), 87-130.

BRAC. (2012). Sierra Leone. 2012 Annual Report.

Brau, J. C., \& Woller, G. M. (2004). Microfinance: A comprehensive review of the existing literature. Journal of Entrepreneurial Finance, JEF, 9(1), 1-27.

Buckley, G. (1997). Microfinance in Africa: Is it either the problem or the solution? World Development, 25(7), 1081-1093. 
Camerer, C. F., \& Fehr, E. (2002). Measuring social norms and preferences using experimental games: A guide for social scientists.

Carpenter, J., \& Williams, T. (2010a). Moral hazard, peer monitoring, and microcredit: field experimental evidence from Paraguay: Working paper series//Federal Reserve Bank of Boston.

Carpenter, J., \& Williams, T. (2010b). Peer monitoring and microcredit: Field experimental evidence from Paraguay: working paper.

Cassar, A., Crowley, L., \& Wydick, B. (2007). The effect of social capital on group loan repayment: evidence from field experiments. The Economic Journal, 117(517), F85-F106.

Charness, G., Gneezy, U., \& Imas, A. (2013). Experimental methods: Eliciting risk preferences. Journal of Economic Behavior \& Organization, 87, 43-51.

Chowdhury, P. R. (2005). Group-lending: Sequential financing, lender monitoring and joint liability. Journal of Development Economics, 77(2), 415-439.

Cordaid. (2013). Sierra Leone - Mobile Money Transfer Market Study: Cordaid.

Cull, R., \& Morduch, J. (2007). Financial performance and outreach: a global analysis of leading microbanks. The Economic Journal, 117(517), F107-F133.

Czura, K. (2012). Pay, peek, punish? Repayment, information acquisition and punishment in a microcredit labin-the-field experiment.

Demirgüç-Kunt, A., \& Maksimovic, V. (1999). Institutions, financial markets, and firm debt maturity. Journal of financial economics, 54(3), 295-336.

Eijkel, R. v., Hermes, N., \& Lensink, R. (2007). Group lending and the role of the group leader: Theory and evidence from Eritrea. University of Groningen.

Fan, J. P., Titman, S., \& Twite, G. (2012). An international comparison of capital structure and debt maturity choices. Journal of financial and quantitative analysis, 47(1), 23.

Fernando, J. L. (1997). Nongovernmental organizations, micro-credit, and empowerment of women. The ANNALS of the American Academy of Political and Social Science, 554(1), 150-177.

Gangopadhyay, S., Ghatak, M., \& Lensink, R. (2005). Joint Liability Lending and the Peer Selection Effect. The Economic Journal, 115(506), 1005-1015.

Garmaise, M. J., \& Natividad, G. (2010). Information, the Cost of Credit, and Operational Efficiency: An Empirical Study of Microfinance. Review of Financial Studies, 23(6), 2560-2590.

Ghatak, M. (1999). Group lending, local information and peer selection. Journal of Development Economics, $60(1), 27-50$.

Ghatak, M. (2000). Screening by the company you keep: Joint liability lending and the peer selection effect. The Economic Journal, 110(465), 601-631.

Ghatak, M., \& Guinnane, T. W. (1999). The economics of lending with joint liability: theory and practice. Journal of Development Economics, 60(1), 195-228.

Giné, X., \& Karlan, D. S. (2014). Group versus individual liability: Short and long term evidence from Philippine microcredit lending groups. Journal of Development Economics, 107, 65-83. 
Godquin, M. (2004). Microfinance repayment performance in Bangladesh: How to improve the allocation of loans by MFIs. World Development, 32(11), 1909-1926.

Guerra, G., Patuelli, R., \& Maggi, R. (2012). Ethnic concentration, cultural identity and immigrant selfemployment in Switzerland. Migration Impact Assessment: New Horizons, 147-171.

Guttman, J. M. (2008). Assortative matching, adverse selection, and group lending. Journal of Development Economics, 87(1), 51-56.

Herfindahl, O. C. (1950). Concentration in the steel industry. Columbia University.

Hermes, N., \& Lensink, R. (2007). The empirics of microfinance: what do we know? The Economic Journal, 117(517), F1-F10.

Hirschman, A. 0.(1945) National Power and the Structure of Foreign Trade. Berkeley: Univ. of California Press.

Huppi, M., \& Feder, G. (1990). The role of groups and credit cooperatives in rural lending. The World Bank Research Observer, 5(2), 187-204.

Kamara, K. S. (2008, October 23). Sierra Leone: Microfinance Demand and Stakeholders' Perceptions of Impact, Africa News Service

Karlan, D., \& Zinman, J. (2009). Observing unobservables: Identifying information asymmetries with a consumer credit field experiment. Econometrica, 77(6), 1993-2008.

Karlan, D. S. (2007). Social connections and group banking. The Economic Journal, 117(517), F52-F84.

Lensink, R., \& Mehrteab, H. T. (2003). Risk behaviour and group formation in microcredit groups in Eritrea, University of Groningen.

Li, D., \& Ferreira, M. P. (2011). Institutional environment and firms' sources of financial capital in Central and Eastern Europe. Journal of Business Research, 64(4), 371-376.

Macedo, E. O. d. (2013). Are defaults a family affair?: the relationship between kinship and microloan performance.

Marr, A. (2002). Studying group dynamics: an alternative analytical framework for the study of microfinance impacts on poverty reduction. Journal of International Development, 14(4), 511-534.

Moss, T. W., Neubaum, D. O., \& Meyskens, M. (2014). The Effect of Virtuous and Entrepreneurial Orientations on Microfinance Lending and Repayment: A Signaling Theory Perspective. Entrepreneurship Theory and Practice.

Olomola, A. S. (2002). Social capital, microfinance group performance and poverty implications in Nigeria. Ibadan, Nigeria: Nigerian Institute of Social and Economic Research.

Paxton, J., Graham, D., \& Thraen, C. (2000). Modeling group loan repayment behavior: New insights from Burkina Faso. Economic Development and Cultural Change, 48(3), 639-655.

Perrault, F., Baldeh, Y., Wahome, J., \& Zayid, J. (2013). Sierra Leone: Country Strategy Paper 2013-2017: African Development Bank Group.

Presbitero, A. F., \& Rabellotti, R. (2014). Geographical distance and moral hazard in microcredit: evidence from Colombia. Journal of International Development, 26(1), 91-108. 
Rankin, K. N. (2002). Social capital, microfinance, and the politics of development. Feminist economics, 8(1), 124.

Sadoulet, L. (1997). The role of mutual insurance in group lending. Department of Economics, Princeton U., manuscript.

Sadoulet, L. (1999). Equilibrium risk-matching in group lending. ECARES, Free University of Brussels.

Sadoulet, L., \& Carpenter, S. B. (2001). Endogenous Matching and Risk Heterogeneity: Evidence on microcredit group formation in Guatemala. ECARES, Free University of Brussels.

Stiglitz, J. E. (1990). Peer monitoring and credit markets. The world bank economic review, 4(3), 351-366.

Stiglitz, J. E., \& Weiss, A. (1981). Credit rationing in markets with imperfect information. The American economic review, 393-410.

UNCDF. (2009). Final Evaluation: Development of a Sustainable Pro-Poor Financial Sector in Sierra Leone: UNCDF.

Van Tassel, E. (1999). Group lending under asymmetric information. Journal of Development Economics, 60(1), 3-25.

Voors, M., Nillesen, E. E., Verwimp, P., Bulte, E. H., Lensink, R., \& Van Soest, D. (2010). Does conflict affect preferences? Results from field experiments in Burundi. Results from Field Experiments in Burundi (January 3, 2010).

Westover, J. (2008). The record of microfinance: The effectiveness/ineffectiveness of microfinance programs as a means of alleviating poverty. Electronic Journal of Sociology, 12(1).

Wydick, B. (1999). Can social cohesion be harnessed to repair market failures? Evidence from group lending in Guatemala. The Economic Journal, 109(457), 463-475.

Wydick, B. (2001). Group lending under dynamic incentives as a borrower discipline device. Review of Development Economics, 5(3), 406-420. 
APPENDIX A. BRAC 


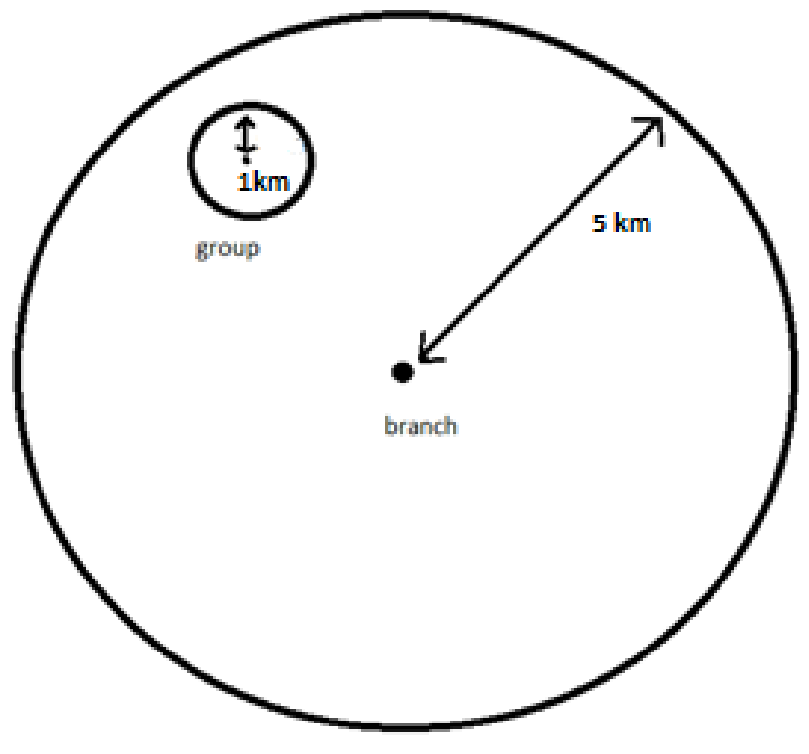

FIGURE 6 BRANCH

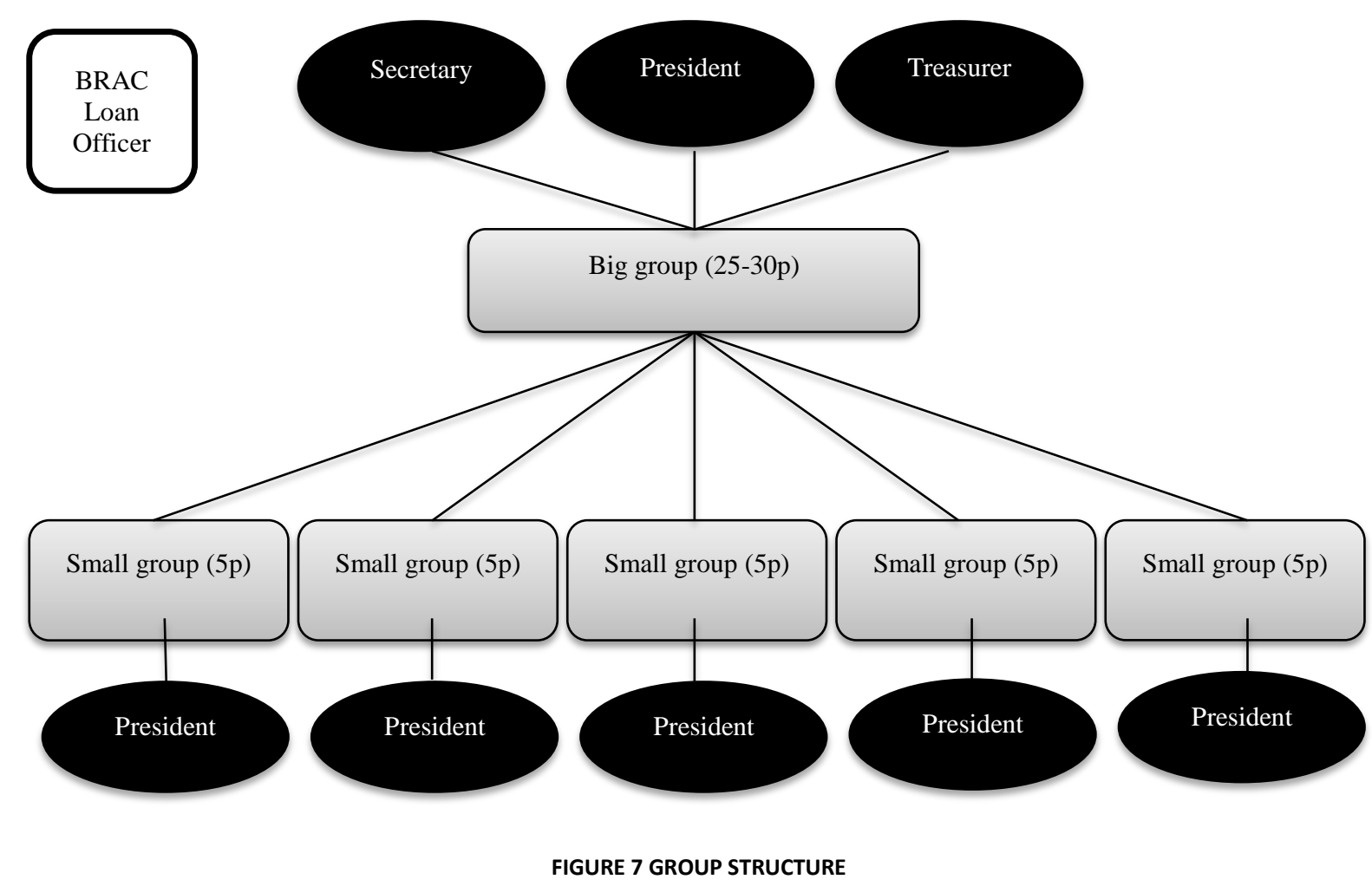




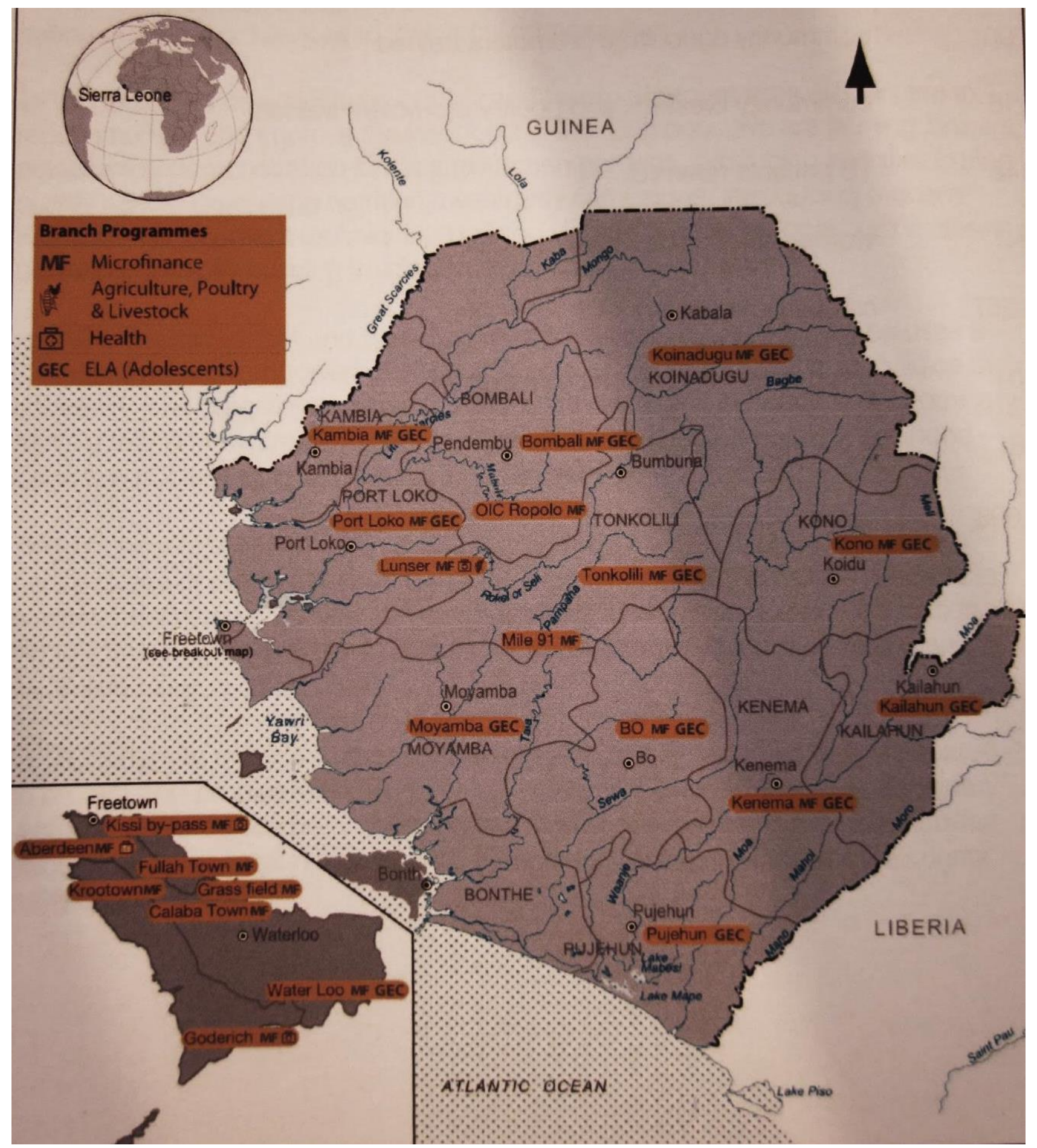

FIGURE 8 MAP BRANCHES BRAC 
APPENDIX B. TABLES 
TABLE A1 VARIABLE DEFINITIONS AND QUESTIONS

\begin{tabular}{|c|c|c|c|}
\hline Variable & Definition & Question in survey & Answers \\
\hline Age & Age measured in years & What is your age? & In amount \\
\hline Household size & $\begin{array}{l}\text { Number of people living under the same roof } \\
\text { and eating from the same pot for a } \\
\text { minimum of six months per year }\end{array}$ & $\begin{array}{l}\text { How many people live in your household? } \\
\text { (Household; eat from the same pot and sleep } \\
\text { under the same roof for minimum of six months) }\end{array}$ & In amount \\
\hline Education & $\begin{array}{l}\text { Level of completed education. In regressions } \\
\text { variable is dummy variable taking unity if } \\
\text { member is literate, zero elsewhere }\end{array}$ & What is your education? & $\begin{array}{l}\text { 1. None } \\
\text { 2. Some primary } \\
\text { school } \\
\text { 3.Completed primary } \\
\text { school } \\
\text { 4. Some JSS } \\
\text { 5. Completed JSS } \\
\text { 6. Some SS } \\
\text { 7.Completed SS } \\
\text { 8. Some college } \\
\text { 9. Completed college } \\
\text { 10. Arabic education } \\
\text { 11. Other, specify }\end{array}$ \\
\hline Position in community & $\begin{array}{l}\text { Position in the community, such as wife of } \\
\text { chief or women's leader. In regressions } \\
\text { variable is dummy variable } \\
\text { taking unity if member has a position in the } \\
\text { community, zero elsewhere }\end{array}$ & What is your position in the community? & $\begin{array}{l}\text { 0. None } \\
\text { 1. Wife of the chief } \\
\text { 2. Women's leader } \\
\text { 3. Youth Leader } \\
\text { 4. Union board } \\
\text { 5. Other, specify }\end{array}$ \\
\hline Business plans & $\begin{array}{l}\text { Whether member has plans to start a new } \\
\text { business. In regressions variable is dummy } \\
\text { variable taking unity if member wants to start } \\
\text { a new business, zero elsewhere }\end{array}$ & $\begin{array}{l}\text { Do you have any new business plans you } \\
\text { want to start? }\end{array}$ & $\begin{array}{l}\text { 0. No } \\
\text { 1. Yes }\end{array}$ \\
\hline
\end{tabular}




\begin{tabular}{|c|c|c|c|}
\hline Loans & $\begin{array}{l}\text { Whether member or anyone else in the } \\
\text { household has a loan with another } \\
\text { organisation. In regressions variable is } \\
\text { dummy variable taking unity if member or } \\
\text { anyone else in the household has a loan, zero } \\
\text { elsewhere }\end{array}$ & $\begin{array}{l}\text { Do you or does anyone else in your household } \\
\text { have an outstanding loan? }\end{array}$ & $\begin{array}{l}\text { 0. No } \\
\text { 1. Yes }\end{array}$ \\
\hline Health & $\begin{array}{l}\text { Perceived health status by the member } \\
\text { herself. It is rated between } \\
1 \text { (good) and } 3 \text { (bad) }\end{array}$ & How do you perceive your current health status? & $\begin{array}{l}\text { 1. Good } \\
\text { 2. Average } \\
\text { 3. Bad }\end{array}$ \\
\hline Temne & $\begin{array}{l}\text { Whether member's ethnicity is Temne. In } \\
\text { regressions variable is dummy variable taking } \\
\text { unity if member is Temne, zero elsewhere }\end{array}$ & What is your tribe? & $\begin{array}{l}\text { 1. Mende } \\
\text { 2. Temne } \\
\text { 3. Fulla } \\
\text { 4. Gola } \\
\text { 5. Limba } \\
\text { 6. Gbandi } \\
\text { 7. Kissi } \\
\text { 8. Vai } \\
\text { 9. Madingo } \\
\text { 10. Other, specify }\end{array}$ \\
\hline Muslim & $\begin{array}{l}\text { Whether member's religion is Muslim. In } \\
\text { regressions variable is dummy variable taking } \\
\text { unity if member is Muslim, zero elsewhere }\end{array}$ & What is your religion? & $\begin{array}{l}\text { 1. Christian } \\
\text { 2. Muslim } \\
\text { 3. Other, specify }\end{array}$ \\
\hline Attendance & Attendance of the weekly meetings. & Do you attend the weekly meetings? & $\begin{array}{l}\text { 1. Always } \\
\text { 2. Often } \\
\text { 3. Sometimes } \\
\text { 4. Never }\end{array}$ \\
\hline Member unable to repay & $\begin{array}{l}\text { Whether one of the present group members } \\
\text { ever has been unable to repay her loan. }\end{array}$ & $\begin{array}{l}\text { Has one of your PRESENT group members ever } \\
\text { been unable to repay the weekly repayment? }\end{array}$ & $\begin{array}{l}\text { 0. No } \\
\text { 1. Yes }\end{array}$ \\
\hline Risk & $\begin{array}{l}\text { Risk preference of the microfinance } \\
\text { members, ranging between risk averse and } \\
\text { risk taking. With the help of a risk game, a } \\
\text { count variable was made. }\end{array}$ & N.A. & Count variable (1-7) \\
\hline
\end{tabular}




\begin{tabular}{|c|c|c|c|}
\hline HHI risk & $\begin{array}{l}\text { Level of risk homogeneity of a microfinance } \\
\text { group. Calculated with a } \\
\text { Herfindahl-Hirschmann Index using the } \\
\text { individual outcomes of the risk variable. }\end{array}$ & N.A. & Index (0-1) \\
\hline Small group size & $\begin{array}{l}\text { Amount of members who are together in a } \\
\text { small microfinance group }\end{array}$ & N.A. & In amount \\
\hline $\begin{array}{l}\text { Coordination game group } \\
\text { total }\end{array}$ & $\begin{array}{l}\text { Method to measure information asymmetry. } \\
\text { The total amount of Leones earned by a } \\
\text { microfinance group after all members played } \\
\text { the coordination game }\end{array}$ & N.A. & In Leones \\
\hline $\begin{array}{l}\text { Coordination game } \\
\text { average per member }\end{array}$ & $\begin{array}{l}\text { Method to measure information asymmetry. } \\
\text { The total amount of Leones earned by a } \\
\text { microfinance group after all members played } \\
\text { the coordination game divided by the total } \\
\text { amount of members }\end{array}$ & N.A. & In Leones \\
\hline Big group size & $\begin{array}{l}\text { Amount of members who are together in a } \\
\text { big microfinance group }\end{array}$ & N.A. & In amount \\
\hline
\end{tabular}


TABLE A2 REPAYMENT PER SMALL GROUP

\begin{tabular}{|c|c|c|c|c|c|}
\hline $\begin{array}{l}\text { Small } \\
\text { Group }\end{array}$ & Obs & Mean & Std. Dev & Min & Max \\
\hline 1 & 216 & .57 & .49 & 0 & 1 \\
\hline 2 & 249 & .79 & .41 & 0 & 1 \\
\hline 3 & 325 & .68 & .47 & 0 & 1 \\
\hline 4 & 198 & .80 & .40 & 0 & 1 \\
\hline 5 & 276 & .73 & .45 & 0 & 1 \\
\hline 6 & 177 & .70 & .46 & 0 & 1 \\
\hline 7 & 53 & .96 & .19 & 0 & 1 \\
\hline 9 & 166 & .65 & .48 & 0 & 1 \\
\hline 10 & 125 & .46 & .50 & 0 & 1 \\
\hline 11 & 225 & .58 & .49 & 0 & 1 \\
\hline 12 & 165 & .76 & .43 & 0 & 1 \\
\hline 13 & 95 & .61 & .49 & 0 & 1 \\
\hline 14 & 220 & .68 & .47 & 0 & 1 \\
\hline 15 & 202 & .65 & .48 & 0 & 1 \\
\hline 16 & 321 & .64 & .48 & 0 & 1 \\
\hline 17 & 122 & .74 & .44 & 0 & 1 \\
\hline 18 & 267 & .68 & .47 & 0 & 1 \\
\hline 19 & 265 & .60 & .49 & 0 & 1 \\
\hline 20 & 175 & .80 & .40 & 0 & 1 \\
\hline 21 & 165 & .65 & .48 & 0 & 1 \\
\hline 22 & 273 & .67 & .47 & 0 & 1 \\
\hline 23 & 242 & .73 & .44 & 0 & 1 \\
\hline 24 & 177 & .42 & .49 & 0 & 1 \\
\hline 25 & 180 & .54 & .50 & 0 & 1 \\
\hline 26 & 241 & .42 & .49 & 0 & 1 \\
\hline 27 & 74 & .38 & .49 & 0 & 1 \\
\hline 28 & 156 & .56 & .50 & 0 & 1 \\
\hline 29 & 102 & .58 & .50 & 0 & 1 \\
\hline 30 & 148 & .54 & .50 & 0 & 1 \\
\hline 31 & 108 & .69 & .46 & 0 & 1 \\
\hline 32 & 220 & .60 & .49 & 0 & 1 \\
\hline 33 & 12 & .75 & .45 & 0 & 1 \\
\hline 34 & 200 & .72 & .45 & 0 & 1 \\
\hline 35 & 220 & .84 & .37 & 0 & 1 \\
\hline 36 & 208 & .73 & .44 & 0 & 1 \\
\hline
\end{tabular}

\begin{tabular}{|c|c|c|c|c|c|}
\hline $\begin{array}{l}\text { Small } \\
\text { Group }\end{array}$ & Obs & Mean & Std. Dev & Min & Max \\
\hline 37 & 155 & .81 & .40 & 0 & 1 \\
\hline 38 & 208 & .71 & .46 & 0 & 1 \\
\hline 39 & 81 & .70 & .46 & 0 & 1 \\
\hline 40 & 161 & .71 & .46 & 0 & 1 \\
\hline 41 & 168 & .78 & .42 & 0 & 1 \\
\hline 43 & 102 & .87 & .33 & 0 & 1 \\
\hline 44 & 110 & .81 & .39 & 0 & 1 \\
\hline 45 & 158 & .85 & .35 & 0 & 1 \\
\hline 46 & 108 & .66 & .48 & 0 & 1 \\
\hline 47 & 180 & .59 & .49 & 0 & 1 \\
\hline 48 & 226 & .58 & .49 & 0 & 1 \\
\hline 49 & 166 & .64 & .48 & 0 & 1 \\
\hline 50 & 275 & .63 & .48 & 0 & 1 \\
\hline 51 & 25 & .72 & .46 & 0 & 1 \\
\hline 52 & 161 & .62 & .49 & 0 & 1 \\
\hline 53 & 259 & .61 & .49 & 0 & 1 \\
\hline 54 & 273 & .50 & .50 & 0 & 1 \\
\hline 55 & 240 & .56 & .50 & 0 & 1 \\
\hline 56 & 197 & .64 & .48 & 0 & 1 \\
\hline 57 & 260 & .75 & .43 & 0 & 1 \\
\hline 58 & 252 & .73 & .45 & 0 & 1 \\
\hline 59 & 330 & .65 & .48 & 0 & 1 \\
\hline 60 & 215 & .51 & .50 & 0 & 1 \\
\hline 61 & 189 & .58 & .50 & 0 & 1 \\
\hline 62 & 217 & .65 & .48 & 0 & 1 \\
\hline 63 & 104 & .80 & .40 & 0 & 1 \\
\hline 64 & 94 & .80 & .40 & 0 & 1 \\
\hline 65 & 131 & .75 & .43 & 0 & 1 \\
\hline 66 & 77 & .58 & .50 & 0 & 1 \\
\hline 67 & 50 & .50 & .50 & 0 & 1 \\
\hline 68 & 50 & .74 & .44 & 0 & 1 \\
\hline 69 & 51 & .78 & .42 & 0 & 1 \\
\hline 70 & 62 & .81 & .40 & 0 & 1 \\
\hline 71 & 87 & .75 & .44 & 0 & 1 \\
\hline 72 & 145 & .67 & .47 & 0 & 1 \\
\hline 73 & 142 & .62 & .49 & 0 & 1 \\
\hline
\end{tabular}


TABLE A3 REPAYMENT PER WEEK

\begin{tabular}{|c|c|c|c|c|c|}
\hline Week & Obs & Mean & Std. Dev. & Min & Max \\
\hline 1 & 187 & .72 & .45 & 0 & 1 \\
\hline 2 & 187 & .40 & .49 & 0 & 1 \\
\hline 3 & 187 & .28 & .45 & 0 & 1 \\
\hline 4 & 197 & .72 & .45 & 0 & 1 \\
\hline 5 & 197 & .70 & .46 & 0 & 1 \\
\hline 6 & 197 & .64 & .48 & 0 & 1 \\
\hline 7 & 197 & .60 & .49 & 0 & 1 \\
\hline 8 & 197 & .36 & .48 & 0 & 1 \\
\hline 9 & 201 & .71 & .46 & 0 & 1 \\
\hline 10 & 201 & .66 & .47 & 0 & 1 \\
\hline 11 & 201 & .73 & .44 & 0 & 1 \\
\hline 12 & 201 & .62 & .49 & 0 & 1 \\
\hline 13 & 188 & .72 & .45 & 0 & 1 \\
\hline 14 & 188 & .48 & .50 & 0 & 1 \\
\hline 15 & 188 & .04 & .19 & 0 & 1 \\
\hline 16 & 188 & .12 & .32 & 0 & 1 \\
\hline 17 & 189 & .78 & .42 & 0 & 1 \\
\hline 18 & 190 & .46 & .50 & 0 & 1 \\
\hline 19 & 191 & .77 & .42 & 0 & 1 \\
\hline 20 & 194 & .88 & .32 & 0 & 1 \\
\hline 21 & 191 & .42 & .49 & 0 & 1 \\
\hline 22 & 176 & .86 & .35 & 0 & 1 \\
\hline 23 & 184 & .90 & .30 & 0 & 1 \\
\hline 24 & 191 & .86 & .34 & 0 & 1 \\
\hline 25 & 190 & .91 & .28 & 0 & 1 \\
\hline 26 & 176 & .17 & .38 & 0 & 1 \\
\hline 27 & 217 & .81 & .39 & 0 & 1 \\
\hline 28 & 217 & .82 & .38 & 0 & 1 \\
\hline 29 & 217 & .66 & .47 & 0 & 1 \\
\hline 30 & 219 & .81 & .39 & 0 & 1 \\
\hline
\end{tabular}

\begin{tabular}{|c|c|c|c|c|c|}
\hline Week & Obs & Mean & Std. Dev. & Min & Max \\
\hline 31 & 220 & .72 & .45 & 0 & 1 \\
\hline 32 & 212 & .82 & .39 & 0 & 1 \\
\hline 33 & 218 & .85 & .35 & 0 & 1 \\
\hline 34 & 222 & .77 & .42 & 0 & 1 \\
\hline 35 & 223 & .82 & .39 & 0 & 1 \\
\hline 36 & 215 & .34 & .47 & 0 & 1 \\
\hline 37 & 232 & .83 & .38 & 0 & 1 \\
\hline 38 & 252 & .82 & .38 & 0 & 1 \\
\hline 39 & 245 & .81 & .39 & 0 & 1 \\
\hline 40 & 234 & .35 & .48 & 0 & 1 \\
\hline 41 & 237 & .32 & .47 & 0 & 1 \\
\hline 42 & 264 & .61 & .49 & 0 & 1 \\
\hline 43 & 268 & .72 & .45 & 0 & 1 \\
\hline 44 & 277 & .80 & .40 & 0 & 1 \\
\hline 45 & 277 & .78 & .41 & 0 & 1 \\
\hline 46 & 277 & .73 & .44 & 0 & 1 \\
\hline 47 & 265 & .78 & .42 & 0 & 1 \\
\hline 48 & 271 & .72 & .45 & 0 & 1 \\
\hline 49 & 269 & .63 & .48 & 0 & 1 \\
\hline 50 & 279 & .85 & .36 & 0 & 1 \\
\hline 51 & 292 & .83 & .38 & 0 & 1 \\
\hline 52 & 297 & .77 & .42 & 0 & 1 \\
\hline 53 & 297 & .73 & .44 & 0 & 1 \\
\hline 54 & 298 & .82 & .38 & 0 & 1 \\
\hline 55 & 292 & .06 & .24 & 0 & 1 \\
\hline
\end{tabular}


TABLE A4 CORRELATION VARIABLES INFORMATION ASYMMETRY

\begin{tabular}{|c|c|c|c|c|c|c|}
\hline & $\begin{array}{c}\text { Coordination game } \\
\text { pay-out }\end{array}$ & $\begin{array}{c}\text { Coordination } \\
\text { game group } \\
\text { total }\end{array}$ & $\begin{array}{l}\text { Coordination } \\
\text { game small } \\
\text { group total }\end{array}$ & HHI Risk & Total links & $\begin{array}{c}\text { Total links small } \\
\text { group }\end{array}$ \\
\hline $\begin{array}{c}\text { Coordination game } \\
\text { pay-out }\end{array}$ & 1.0000 & & & & & \\
\hline $\begin{array}{l}\text { Coordination game } \\
\text { group total }\end{array}$ & $\begin{array}{c}0.4093^{*} \\
0.0000\end{array}$ & 1.0000 & & & & \\
\hline $\begin{array}{l}\text { Coordination game } \\
\text { small group total }\end{array}$ & $\begin{array}{c}0.6533^{*} \\
0.0000\end{array}$ & $\begin{array}{l}0.6118^{*} \\
0.0000\end{array}$ & 1.0000 & & & \\
\hline HHI Risk & $\begin{array}{l}-0.0462 \\
0.4196\end{array}$ & $\begin{array}{l}-0.0148 \\
0.7959\end{array}$ & $\begin{array}{l}-0.1036 \\
0.0700\end{array}$ & 1.0000 & & \\
\hline Total links & $\begin{array}{c}0.1686 * \\
0.0031\end{array}$ & $\begin{array}{l}-0.0210 \\
0.7146\end{array}$ & $\begin{array}{c}0.2827^{*} \\
0.0000\end{array}$ & $\begin{array}{c}-0.0892 \\
0.1187\end{array}$ & 1.0000 & \\
\hline $\begin{array}{l}\text { Total links small } \\
\text { group }\end{array}$ & $\begin{array}{l}0.0986 \\
0.0865\end{array}$ & $\begin{array}{l}0.0162 \\
0.7789\end{array}$ & $\begin{array}{c}0.1567 * \\
0.0063\end{array}$ & $\begin{array}{c}-0.0797 \\
0.1665\end{array}$ & $\begin{array}{c}0.5563^{*} \\
0.0000\end{array}$ & 1.0000 \\
\hline
\end{tabular}


TABLE A4 CORRELATION HERFINDAHL INDICES

\begin{tabular}{|c|c|c|c|c|c|c|c|c|}
\hline & HHI Risk & HHI Age & HHI Education & HHI Temne & $\begin{array}{c}\mathrm{HHI} \\
\text { Position in } \\
\text { the } \\
\text { community }\end{array}$ & HHI Muslim & HHI Occupation & $\begin{array}{c}\mathrm{HHI} \\
\begin{array}{c}\text { Entrepreunerial } \\
\text { behaviour }\end{array} \\
\end{array}$ \\
\hline \multirow{2}{*}{\multicolumn{9}{|c|}{ HHI Risk }} \\
\hline & & & & & & & & \\
\hline & $0.3340 *$ & 1.0000 & & & & & & \\
\hline HHI Age & 0.0000 & & & & & & & \\
\hline & -0.0326 & $0.2000^{*}$ & 1.0000 & & & & & \\
\hline HHI Education & 0.5696 & 0.0004 & & & & & & \\
\hline & $0.3392 *$ & $0.9030 *$ & 0.0750 & 1.0000 & & & & \\
\hline HHI Temne & 0.0000 & 0.0000 & 0.1900 & & & & & \\
\hline $\begin{array}{l}\text { HHI Position in the } \\
\text { community }\end{array}$ & $\begin{array}{l}0.0825 \\
0.1494\end{array}$ & $\begin{array}{c}0.6086^{*} \\
0.0000\end{array}$ & $\begin{array}{c}0.3324 * \\
0.0000\end{array}$ & $\begin{array}{c}0.4993^{*} \\
0.0000\end{array}$ & 1.0000 & & & \\
\hline HHI Muslim & $\begin{array}{c}0.4109 * \\
0.0000\end{array}$ & $\begin{array}{c}0.7698^{*} \\
0.0000\end{array}$ & $\begin{array}{l}0.1085 \\
0.0576\end{array}$ & $\begin{array}{c}0.7001^{*} \\
0.0000\end{array}$ & $\begin{array}{c}0.4276^{*} \\
0.0000\end{array}$ & 1.0000 & & \\
\hline HHI Occupation & $\begin{array}{c}0.2652^{*} \\
0.0000\end{array}$ & $\begin{array}{c}0.9642^{*} \\
0.0000\end{array}$ & $\begin{array}{c}0.1853^{*} \\
0.0011\end{array}$ & $\begin{array}{c}0.8677^{*} \\
0.0000\end{array}$ & $\begin{array}{c}0.6036^{*} \\
0.0000\end{array}$ & $\begin{array}{c}0.7228^{*} \\
0.0000\end{array}$ & 1.0000 & \\
\hline $\begin{array}{l}\mathrm{HHI} \text { Entrepreunerial } \\
\text { behaviour }\end{array}$ & $\begin{array}{c}-0.0386 \\
0.5008\end{array}$ & $\begin{array}{c}0.3341 * \\
0.0000\end{array}$ & $\begin{array}{l}0.1056 \\
0.0647\end{array}$ & $\begin{array}{c}0.2133^{*} \\
0.0002\end{array}$ & $\begin{array}{c}0.1451 * \\
0.0109\end{array}$ & $\begin{array}{c}0.2385^{*} \\
0.0000\end{array}$ & $\begin{array}{c}0.3166^{*} \\
0.0000\end{array}$ & 1.0000 \\
\hline
\end{tabular}


Appendix C. Repayment SHEet 


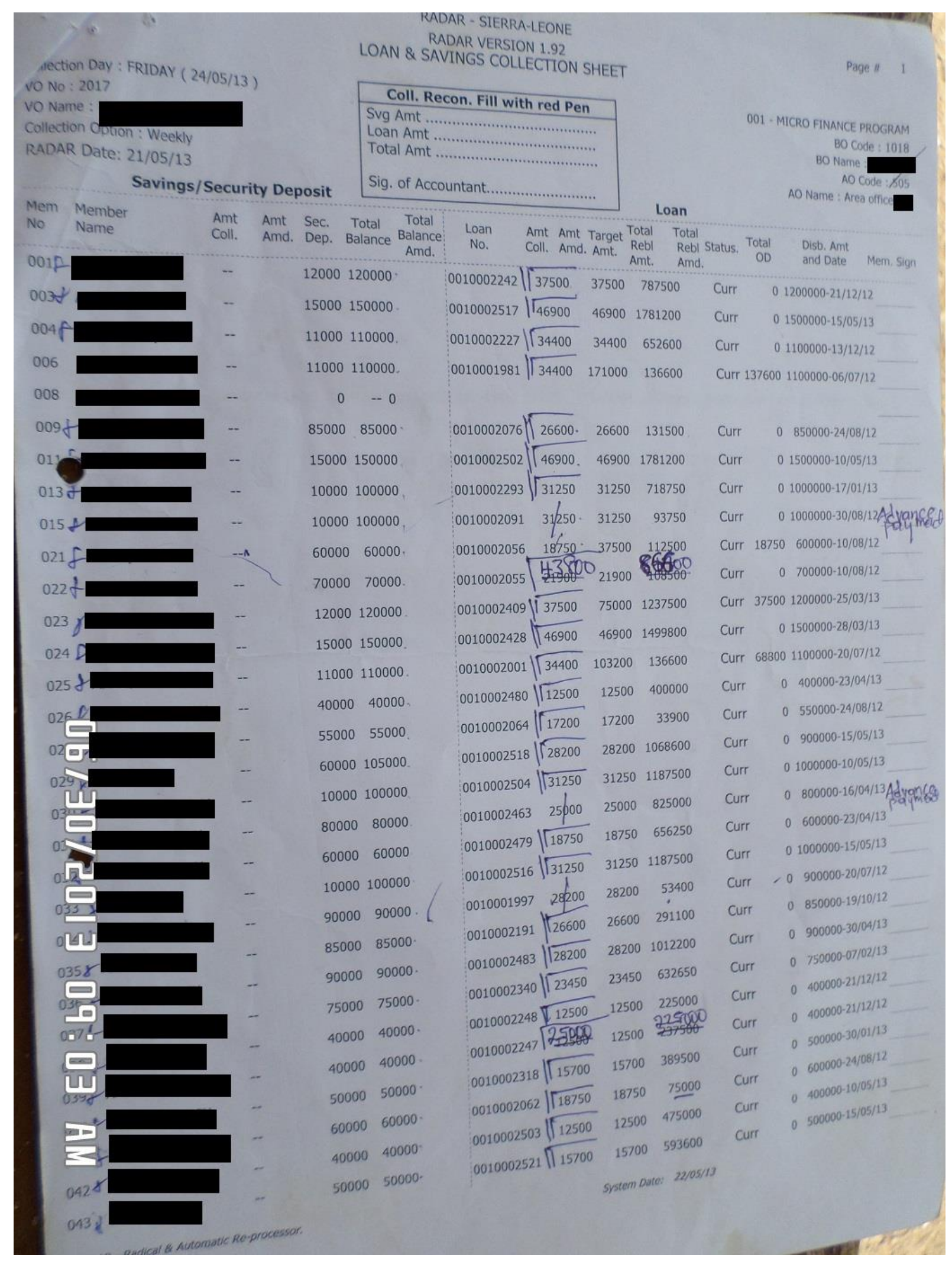

FIGURE 9 REPAYMENT SHEET EXAMPLE 
APPENDIX D. INSTRUMENTS 
Give the informed consent form to the participant and talk it through with them.

My name is I am a research associate hired by BRAC Sierra Leone, Wageningen University and Njala University. I am here to conduct a study on BRAC's microfinance services in Sierra Leone.

Before we begin, I would like to take a minute to explain why I am inviting you to participate and what I will be doing with the information you provide to me. Please stop me at any time if you have any questions.

This research is being conducted by researchers from BRAC Sierra Leone, Wageningen University and Njala University. We will be interviewing in 8 branches all over Sierra Leone. The researchers will use the provided information in articles that might be published, as well as in publications for improving BRAC's microfinance services in the future.

Participation should take about an hour. Participation is on voluntary basis. Some of you will be asked to participate in an activity.There are minimal risks to you from answering these questions. The information we collect today is private and confidential. We will not share any details from the survey with anyone besides the research team from Wageningen University. These surveys will go to a secure location at Wageningen University, in The Netherlands.

If at any time and for any reason, you would prefer not to answer any questions, please feel free not to. If at any time you would like to stop participating, please tell me. We can take a break, stop and continue at a later date, or stop altogether.

If you have questions, you are free to ask them now. If you have questions later, you may call the research supervisor, Karen van Zaal, at 077-337361. Or you can contact Sajal Roy, Senior Research Associate of BRAC Sierra Leone, at 076-885164.

Sajal Roy

Senior Research Associate and Coordinator

Research \& Evaluation Unit

BRAC Sierra Leone

174 Wilkinson Road

Freetown
Karen van Zaal

Research Supervisor Wageningen University

Wageningen

The Netherlands 


\section{Evaluation MF BRAC Sierra Leone 2014}

\section{PART 1}

Group Member Survey

\begin{tabular}{|l|l|l|l|}
\hline Branch & Code & \\
\hline Group & Code & \\
\hline Loan officer & Code & \\
\hline MF member & Code & \\
\hline
\end{tabular}

\section{DATA COLLECTION}

\begin{tabular}{|c|c|c|c|}
\hline Enumerator & Code & Date & $-J_{-} \Lambda_{-}$ \\
\hline RA Team & Code & Date & $-I_{-} I_{-}$ \\
\hline Supervisor & Code & Date & $-I_{-} I_{-}$ \\
\hline
\end{tabular}

DATA ENTRY

\begin{tabular}{|c|c|c|c|}
\hline Enumerator 1 & Code & Date & $I_{-} I_{-}$ \\
\hline Enumerator 2 & Code & Date & $I_{-} I_{-}$ \\
\hline Supervisor & Code & Date & - \\
\hline
\end{tabular}




\section{MODULE 1: SOCIO-DEMOGRAPHIC PROFILE}

Household: Eating from the same pot and sleeping under the same roof for $\min 6$ months per year

1.1 General information

\begin{tabular}{|c|c|c|c|c|c|c|c|c|}
\hline 1. Full name & 2. Age & 3. Education Level & 4. Tribe & $\begin{array}{l}\text { 5. Position in } \\
\text { Community }\end{array}$ & 6. Religion & $\begin{array}{l}\text { 7. No. of } \\
\text { people in } \\
\mathrm{HH}\end{array}$ & $\begin{array}{l}\text { 8. No. of } \\
\text { Adults }\end{array}$ & $\begin{array}{l}\text { 9. No. of } \\
\text { Children }\end{array}$ \\
\hline Write full name of respondent & Number & $\begin{array}{l}\text { 1. None } \\
\text { 2. Some primary } \\
\text { school } \\
\text { 3.Completed primary } \\
\text { school } \\
\text { 4. Some JSS } \\
\text { 5.Completed JSS } \\
\text { 6. Some SS } \\
\text { 7.Completed SS } \\
\text { 8. Some college } \\
\text { 9. Completed college } \\
\text { 10. Arabic education } \\
\text { 11. Other, specify }\end{array}$ & $\begin{array}{l}\text { 1. Mende } \\
\text { 2. Temne } \\
\text { 3. Fulla } \\
\text { 4. Gola } \\
\text { 5. Limba } \\
\text { 6. Gbandi } \\
\text { 7. Kissi } \\
\text { 8. Vai } \\
\text { 9. Madingo } \\
\text { 10. Other, } \\
\text { specify }\end{array}$ & $\begin{array}{l}\text { 0. None } \\
\text { 1. Wife of the } \\
\text { chief } \\
\text { 2. Women's } \\
\text { leader } \\
\text { 3. Youth Leader } \\
\text { 4. Union board } \\
\text { 5. Other, specify }\end{array}$ & $\begin{array}{l}\text { 1. Christian } \\
\text { 2. Muslim } \\
\text { 3. Other, } \\
\text { specify }\end{array}$ & Amount & Amount & Amount \\
\hline
\end{tabular}

\subsection{Education of children of hh}

\begin{tabular}{|c|c|c|c|c|c|c|}
\hline $\begin{array}{l}\text { 1. How many } \\
\text { children are primary } \\
\text { school aged? } \\
\text { (6-12 years) }\end{array}$ & $\begin{array}{l}\text { 2. How many of } \\
\text { them attend } \\
\text { primary school? }\end{array}$ & $\begin{array}{l}\text { 3. If any do not attend } \\
\text { primary school, why not? }\end{array}$ & $\begin{array}{l}\text { 4. How many children } \\
\text { are secondary school } \\
\text { aged? } \\
\text { (12-18 years) }\end{array}$ & $\begin{array}{l}\text { 5. How many of } \\
\text { them attend } \\
\text { secondary } \\
\text { school? }\end{array}$ & $\begin{array}{l}\text { 6. If any do not attend } \\
\text { secondary school, why not?? }\end{array}$ & $\begin{array}{l}\text { 7. Who pays the } \\
\text { school fees? }\end{array}$ \\
\hline
\end{tabular}




\section{MODULE 2: HOUSING}

\subsection{Assets of hh}

\begin{tabular}{|l|l|l|l|}
\hline Type of asset & $\begin{array}{l}\text { 1. Do you } \\
\text { own this } \\
\text { item? }\end{array}$ & $\begin{array}{l}\text { 2. How } \\
\text { many do } \\
\text { you own? }\end{array}$ & $\begin{array}{l}\text { 3. If you would } \\
\text { buy a similar } \\
\text { item, how } \\
\text { much would 1 } \\
\text { unit cost? }\end{array}$ \\
\hline & $\begin{array}{l}\text { 1. Yes } \\
\text { 2. No }\end{array}$ & $\begin{array}{l}\text { 1. In Leones } \\
\text { 2. Barter system } \\
\text { 3. Inheritage } \\
\text { 4. Community }\end{array}$ \\
\hline 1. Bed & & & \\
\hline 2. Table & & & \\
\hline 3. Chair & & & \\
\hline 4. Chinese lamp (lantern) & & & \\
\hline 5. Cooking pot & & & \\
\hline 6. Bucket & & & \\
\hline 7. Bible/Koran & & & \\
\hline $\begin{array}{l}\text { 8. Homestead } \\
\text { (town lot) }\end{array}$ & & & \\
\hline 9. Shop premises & & & \\
\hline 10. Radio/cassette player & & & \\
\hline 11. Television & & & \\
\hline 12. Electric fan & & & \\
\hline 13. Mobile phone & & & \\
\hline 14. Generator & & & \\
\hline 15. Bicycle & & & \\
\hline 16. Motorbike & & & \\
\hline 17. Refrigerator & & & \\
\hline 18. Sewing machine & & & \\
\hline 19. Computer & & & \\
\hline 20. Other valuable assets & & & \\
\hline
\end{tabular}

\subsection{Housing conditions}

\begin{tabular}{|l|l|}
\hline 1. Pan roof & \\
\hline 2. Mud and sticks walls & \\
\hline 3. Cements walls & \\
\hline 4. Earth floor & \\
\hline 5. Wood floor & \\
\hline 6. Concrete floor & \\
\hline 7. Electricity & \\
\hline 8. Private toilet & \\
\hline
\end{tabular}

\subsection{Ownership}

\begin{tabular}{|c|c|c|}
\hline 1. & $\begin{array}{l}\text { For how long have you been living } \\
\text { in your house? }\end{array}$ & Mention in years \\
\hline 2. & $\begin{array}{l}\text { What is the ownership status of } \\
\text { your house? }\end{array}$ & $\begin{array}{l}\text { 1. Owned and built } \\
\text { 2. Owned and purchased } \\
\text { 3. Owned and inherited } \\
\text { 4. Given as a favour } \\
\text { 5. Rented } \\
\text { 6. Using without paying rent } \\
\text { 7. Temporary dwelling } \\
\text { 8. Other, specify }\end{array}$ \\
\hline 3. & $\begin{array}{l}\text { If owned, what is the value of your } \\
\text { house? }\end{array}$ & Amount in Leones \\
\hline 4. & $\begin{array}{l}\text { If owned, did you made any } \\
\text { renovations to the house past year } \\
(2013) \text { ? }\end{array}$ & $\begin{array}{l}\text { 1. Yes } \\
\text { 2. No }\end{array}$ \\
\hline 5. & If yes, how much did you spend? & Amount in Leones \\
\hline 6. & $\begin{array}{l}\text { If rented, how much do pay per } \\
\text { year? }\end{array}$ & Amount in Leones \\
\hline 7. & $\begin{array}{l}\text { If rented, do you have to pay share } \\
\text { of the renovation costs in } 2013 ?\end{array}$ & $\begin{array}{l}\text { 1. Yes } \\
\text { 2. No }\end{array}$ \\
\hline 8. & $\begin{array}{l}\text { If yes, how much did you had to } \\
\text { pay? }\end{array}$ & Amount in Leones \\
\hline
\end{tabular}




\section{MODULE 3: ECONOMIC AND INCOME RELATED ACTIVITIES}

\subsection{Occupation}

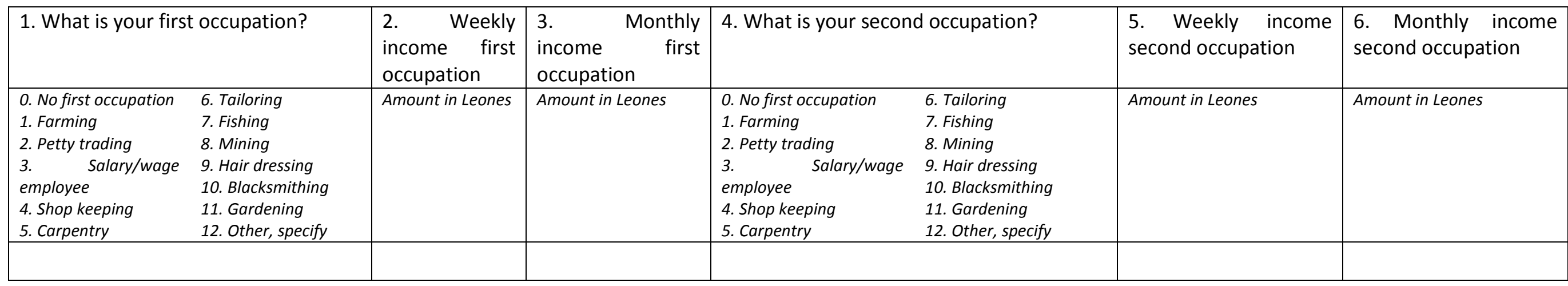

\subsection{Income past five years}

1. Which of the past five years was BEST in terms of household income?

\subsection{Expected income}

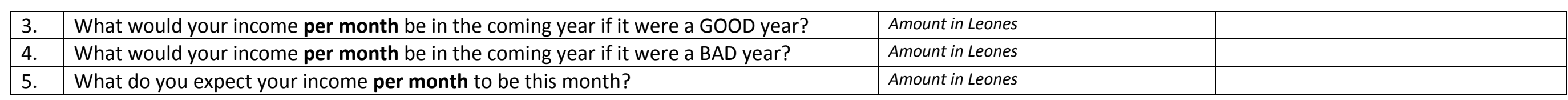


3.4 Business plans

\begin{tabular}{|c|c|c|c|}
\hline $3.4 .1 \quad \mathrm{D}$ & \multicolumn{3}{|c|}{ Do you have any new business plans you want to start? } \\
\hline \multicolumn{4}{|c|}{ 3.4.2 New business plan } \\
\hline $\begin{array}{l}\text { New } \\
\text { business } \\
\text { plan }\end{array}$ & Activity & $\begin{array}{l}\text { 1. Farming } \\
\text { 2. Petty trading } \\
\text { 3. Salary/wage } \\
\text { employee }\end{array}$ & $\begin{array}{l}\text { 7. Tailoring } \\
\text { 8. Fishing } \\
\text { 9. Mining } \\
\text { 10. Hair dressing }\end{array}$ \\
\hline 1. & & 4. International trade & 11. Blacksmithing \\
\hline 2. & & $\begin{array}{l}\text { 5. Shop keeping } \\
\text { 6. Carpeting }\end{array}$ & $\begin{array}{l}\text { 12. Gardening } \\
\text { 13. Other, specify }\end{array}$ \\
\hline 3. & & & \\
\hline
\end{tabular}

\subsection{Outstanding loans}

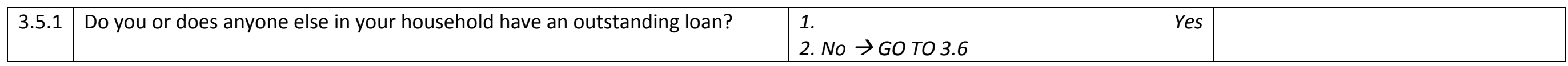

\begin{tabular}{|c|c|c|c|c|}
\hline & 1. Who & 2. From & 3. Amount of loan & 4. Interest rate \\
\hline & $\begin{array}{lr}1 . & \text { Yourself } \\
2 . & \text { Husband } \\
\text { 3. Other hh member }\end{array}$ & $\begin{array}{lrllr}\text { 1. Formal bank } & \text { 4. } & \text { Landlord } & \text { 7. } & \text { Friend/neighbour } \\
\text { 2. } & \text { BRAC } & \text { 5. Employer } & \text { 8. Local money lender } \\
\text { 3. Other MFI } & \text { 6. Relative } & \text { 9. Other, specify }\end{array}$ & Amount in Leones & $\begin{array}{l}\text { 1. In Leones } \\
\text { 2. In percentages }\end{array}$ \\
\hline 1. & & & & \\
\hline 2. & & & & \\
\hline 3. & & & & \\
\hline
\end{tabular}




\subsection{Savings}

\begin{tabular}{|l|l}
\hline 3.6.1 & Do you have (cash) savings? Mbene \\
\hline
\end{tabular}

3.6.2 How much (cash) savings do you have?

3.6.2 How much (cash) savings do you have?
\begin{tabular}{|l|l|l|l|l|}
\hline Do you have: & 1. Savings at home & $\begin{array}{l}\text { 2. Savings with someone } \\
\text { you trust (Osusu) }\end{array}$ & 3. Bank & 4. NGO If NGO, which one \\
\hline Amount you save in Leones & & & & \\
\hline
\end{tabular}

\subsection{Involvement NGOs}

\begin{tabular}{|l|l|l|l|}
\hline 3.7.1 & Do you know other development programs (NGOs) (E'marr) in your community? & 1. Yes; 2. No $\rightarrow$ GO TO MODULE 4 \\
\hline
\end{tabular}

3.7.2 Which other development programs (NGOs) (E'marr) do you know in your community?

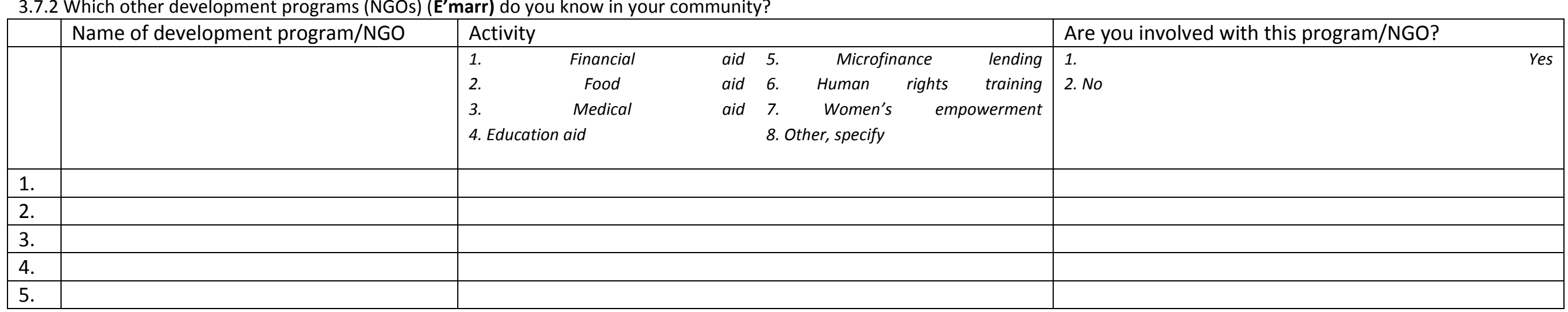

\section{MODULE 4: RISK}

HYPOTHETICAL GAME: Would you like to receive A with certainty or B with flipping a coin (head = receive the money, star = receive nothing)

\begin{tabular}{|c|c|c|c|}
\hline & A & B & A or $B$ \\
\hline 1. & 5.500 Leones with certainty (100\%) & 5.000 Leones with uncertainty (50\%) & \\
\hline 2. & 4.500 Leones with certainty (100\%) & 5.000 Leones with uncertainty (50\%) & \\
\hline 3. & 3.500 Leones with certainty $(100 \%)$ & 5.000 Leones with uncertainty $(50 \%)$ & \\
\hline 4. & 2.500 Leones with certainty (100\%) & 5.000 Leones with uncertainty $(50 \%)$ & \\
\hline 5. & 1.500 Leones with certainty (100\%) & 5.000 Leones with uncertainty (50\%) & \\
\hline 6. & 0.500 Leones with certainty (100\%) & 5.000 Leones with uncertainty $(50 \%)$ & \\
\hline
\end{tabular}




\section{MODULE 5: HEALTH}

\subsection{Health and health access}

\begin{tabular}{|c|c|c|c|}
\hline 5.1 .1 & How do you perceive your current health status? & 1. Good; 2. Average; 3. Bad & \\
\hline 5.1 .2 & How do you consider your health compared to last year? & $\begin{array}{l}\text { 1. Better than last year; } 2 \text {. Same as last year; } 3 \text {. Worse } \\
\text { than last year }\end{array}$ & \\
\hline 5.1 .3 & How many deaths in household last year & Amount & \\
\hline 5.1 .5 & How long will it take you to get to a health centre? & $\begin{array}{l}\text { 0. There is no health centre; } \\
\text { 1. Less than } 15 \mathrm{~min} ; 2.15-30 \mathrm{~min} \text {; } \\
\text { 3. } 30 \text { - } 1 \text { hour; } 4.1 \text { hour; } 5.2 \text { hours or more }\end{array}$ & \\
\hline 5.1 .6 & How long will it take you to get to a hospital? & $\begin{array}{l}\text { 0. There is no hospital; } \\
\begin{array}{lllll}\text { 1. Less than } 15 \quad \mathrm{~min} ; \quad 2 . \quad 15 \quad-30 & \mathrm{~min} \text {; } \\
\text { 3. } 30-1 \text { hour; } 4.1 \text { hour; } 5.2 \text { hours or more } & & \end{array}\end{array}$ & \\
\hline
\end{tabular}

\subsection{Diseases}

For each of the following diseases, how many adults and children in your household had this disease in the last six weeks

\begin{tabular}{|l|l|l|}
\hline & 1. Number of adults & 2. Number of children \\
\hline 1. Malaria & & \\
\hline 2. Diarrhea & & \\
\hline 3. Infection & & \\
\hline 4. Common cold & & \\
\hline 5. Other, specify & & \\
\hline
\end{tabular}

\subsection{Food security}

\begin{tabular}{|c|c|c|}
\hline 5.3 .1 & How many meals do you eat a day & Number of meals a day \\
\hline 5.3 .2 & Do you ever experience hunger? & 1. Yes; 2. Sometimes; 3. No \\
\hline 5.3 .3 & What is your major source of drinking water? & $\begin{array}{l}\text { 1. Handpump; 2. Welled; 3. Bottled; } 4 . \\
\text { Stream; 5. Other, specify }\end{array}$ \\
\hline
\end{tabular}




\section{MODULE 6: CONSUMPTION}

6.1 Food consumption IN ONE DAY of your entire household (eating from the same pot and living under the same roof for minimum of 6 months per year)

\begin{tabular}{|l|l|l|}
\hline $\begin{array}{l}\text { 1. Consumption } \\
\text { good }\end{array}$ & $\begin{array}{l}\text { 2. Did you } \\
\text { consume } \\
\text { good? }\end{array}$ & $\begin{array}{l}\text { 4. If you would buy a similar quantity of this good that } \\
\text { you normally consume, how much would you spend? }\end{array}$ \\
\hline Consumption of one day
\end{tabular}

\subsection{Fractions of revenue spend on different categories}

\begin{tabular}{|c|c|c|c|}
\hline & $\begin{array}{l}\text { How much of your income do you spend on } \\
\text { Total monthly income: }\end{array}$ & Amount in Leones & $\begin{array}{l}\text { Time unit } \\
\text { 1. Month; 2. Year; } \\
\text { 3. Other, specify }\end{array}$ \\
\hline 1. & Consumption & & \\
\hline 2. & Transport & & \\
\hline 3. & Education (uniforms/fees) & & \\
\hline 4 & Health (medicines/doctor) & & \\
\hline 5 & Clothing & & \\
\hline
\end{tabular}




\section{MODULE 7: SATISFACTION}

\subsection{Client satisfaction (Nur ponk barksineh)}

Please ask per question how satisfied they are

\begin{tabular}{|c|c|c|}
\hline & How satisfied are you with? & \multirow{18}{*}{ 1. Highly satisfied } \\
\hline 1. & Loan application system & \\
\hline 2. & Waiting time to receive loan & \\
\hline 3. & Maximum loan size & \\
\hline 4. & Interest rate & \\
\hline 5. & Loan application fee & \\
\hline 6. & Repayment period & \\
\hline 7. & Weekly instalment & \\
\hline 8. & System of paying overdue & \\
\hline 9. & Increase in loan size & \\
\hline 10. & Amount of meeting & \\
\hline 11. & Duration of meeting & \\
\hline 12. & Professional behaviour of Loan officer & \\
\hline 13. & Loan officer's reaction to suggestions & \\
\hline 14. & Accessibility of BRAC & \\
\hline 15. & Distance to branch & \\
\hline 16. & Distance to group meeting & \\
\hline 17. & $\begin{array}{l}\text { In general, how satisfied are you with } \\
\text { BRAC's services }\end{array}$ & \\
\hline
\end{tabular}

\subsection{Depression index}

Please ask per question how often they feel like:

\begin{tabular}{|c|c|c|}
\hline 1. & $\begin{array}{l}\text { I was bothered by things that usually don't } \\
\text { bother me } \\
\text { (bothered = angry/irritated) }\end{array}$ & \multirow{10}{*}{$\begin{array}{l}\text { 1. None or rarely } \\
\text { (less than } 1 \text { day a } \\
\text { week) } \\
\text { 2. Sometimes } \\
\text { (1 to } 2 \text { days a } \\
\text { week) } \\
\text { 3. Occasionally } \\
\text { (3 to } 4 \text { days a } \\
\text { week) } \\
\text { 4. Most of the } \\
\text { time } \\
\text { (5 to } 7 \text { days a } \\
\text { week) }\end{array}$} \\
\hline 2. & $\begin{array}{l}\text { I did not feel like eating; my appetite was } \\
\text { poor }\end{array}$ & \\
\hline 3. & I felt hopeful about the future & \\
\hline 4. & I felt fearless & \\
\hline 5. & I was happy & \\
\hline 6. & I felt lonely & \\
\hline 7. & I enjoyed life & \\
\hline 8. & I could not get going & \\
\hline 9. & I was having trouble sleeping & \\
\hline 10. & I felt that people did not like me & \\
\hline
\end{tabular}

\begin{tabular}{|l|}
\hline \\
\hline \\
\hline \\
\hline \\
\hline \\
\hline \\
\hline \\
\hline \\
\hline
\end{tabular}

7.3 Locus of control
1. With which statement do you agree?
A: everyone is responsible for his success or failure in his life.
2. With which statement do you agree?
$B$ : success or failure in life is for each person a question
A: To be successful, above all, you should work very hard.
B: To be successful, above all, you must have luck 


\subsection{Aspirations}

Have a look at the picture. The first level (10) represents the best possible life for you, the lowest level (1) the worst

\begin{tabular}{|l|l|l|l|}
\hline 1. & On what level are you now? & Level 1-10 & \\
\hline 2. & On what level do you want to be? & Level 1-10 & \\
\hline 3. & $\begin{array}{l}\text { On what level do you think you are } \\
\text { in 5 years? }\end{array}$ & Level 1-10 & \\
\hline
\end{tabular}

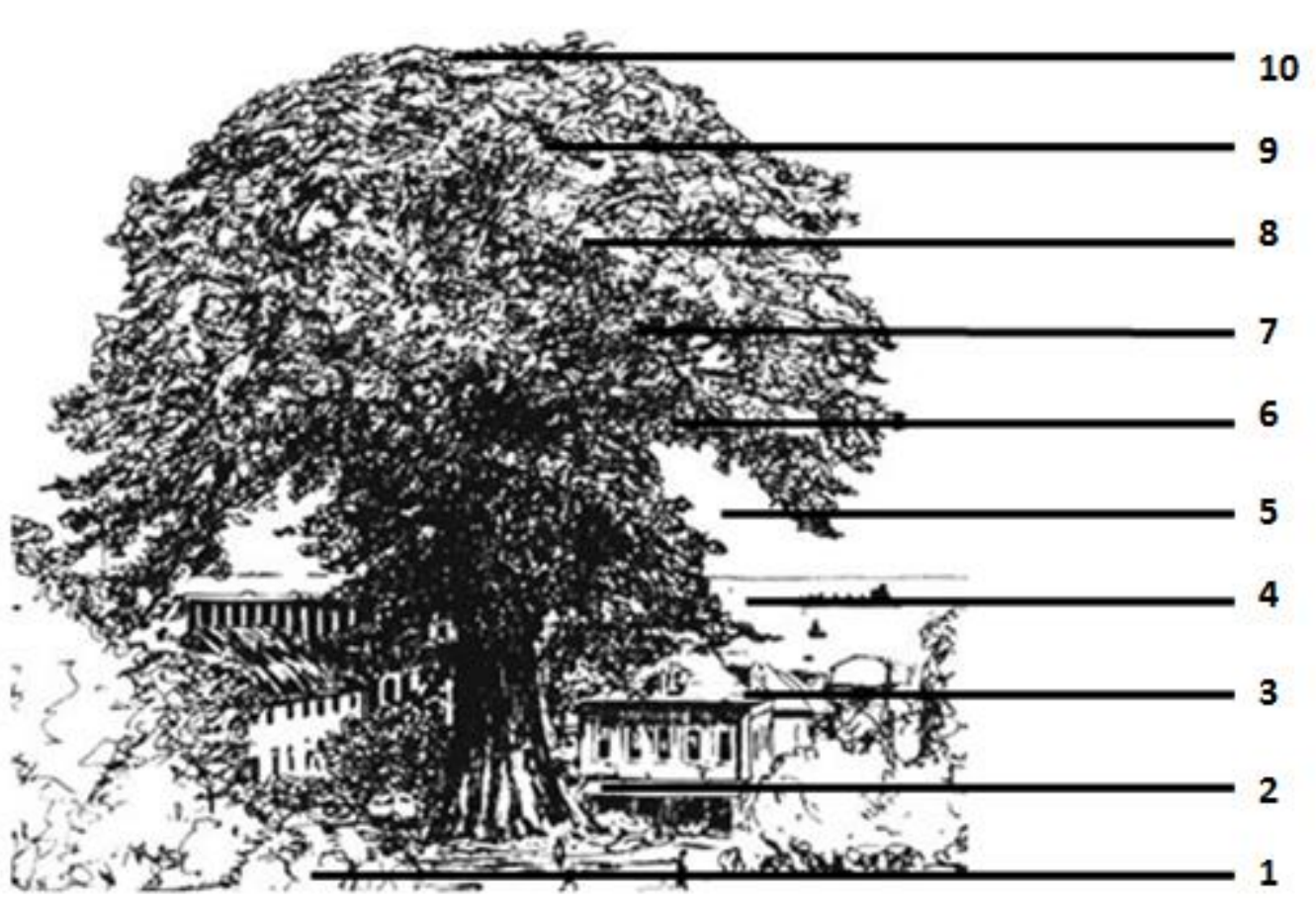

\begin{tabular}{|c|c|c|}
\hline 4. & $\begin{array}{l}\text { In the coming } \mathbf{5} \text { years your } \\
\text { income will be }\end{array}$ & $A=$ much better \\
\hline 5. & $\begin{array}{l}\text { In the coming } 5 \text { years your } \\
\text { health will be }\end{array}$ & $\begin{array}{l}B=\text { better } \\
C=\text { the same }\end{array}$ \\
\hline 6. & $\begin{array}{l}\text { In the coming } 5 \text { years the } \\
\text { opportunities for your children } \\
\text { will be }\end{array}$ & $\begin{array}{l}D=\text { bad } \\
E=\text { much } \text { worse } \\
X=I \text { do not know }\end{array}$ \\
\hline
\end{tabular}

During the next five years I will:

\begin{tabular}{|c|l|l|l|}
\hline 3. & Find a better job & 1. Yes; 2. No & \\
\hline 4. & Improve my education & 1. Yes; 2. No & \\
\hline 5. & Marry and have children & 1. Yes; 2. No & \\
\hline
\end{tabular}

\begin{tabular}{|l|l|l|}
\hline 6. & I strongly pursue my goals & 1. Strongly agree \\
\hline 7. & A problem can be solved on a lot of different ways & 2. Agree \\
\hline 8. & Even when others get discouraged, I know that I can find a way to resolve a problem & 3. Disagree \\
\hline 9. & My past experiences made me well prepared for my future & 4. Strongly disagree \\
\hline 10. & I had some success in life & \\
\hline 11. & I accomplish the goals I set for myself & \\
\hline
\end{tabular}

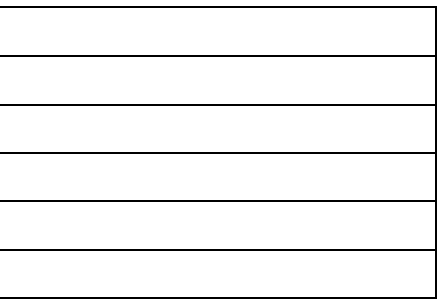




\section{Evaluation MF BRAC Sierra Leone 2014}

\section{PART 2}

Group Member Survey

\begin{tabular}{|l|l|l|l|}
\hline Branch & Code & \\
\hline Group & Code & \\
\hline Loan officer & Code & \\
\hline MF member & Code & \\
\hline
\end{tabular}

\section{DATA COLLECTION}

\begin{tabular}{|c|c|c|c|}
\hline Enumerator & Code & Date & $-J_{-} I_{-}$ \\
\hline Supervisor & Code & Date & $I_{-} I_{-}$ \\
\hline
\end{tabular}

\section{DATA ENTRY}

\begin{tabular}{|l|l|l|l|l|l|}
\hline Enumerator 1 & & Code & & Date & $\left.-\lrcorner_{-}\right\lrcorner_{--}$ \\
\hline Enumerator 2 & & Code & & Date & $-\lrcorner_{-\lrcorner_{--}}$ \\
\hline Supervisor & & Code & & Date & \lrcorner$\left.\left._{-}\right\lrcorner_{-}\right\lrcorner_{--}$ \\
\hline
\end{tabular}




\section{MODULE 8: GROUP}

\subsection{Group information}

\begin{tabular}{|c|c|c|c|}
\hline 1. & When did you become a member of the group? & Month - Year & \\
\hline 2. & When did you become a member of BRAC? & Month-Year & \\
\hline 3. & When did you receive your first loan? & Month - Year & \\
\hline 4. & When was the group formed? & Month - Year & \\
\hline 5. & Have you been a member of this group since it started? & 1. Yes; 2. No & \\
\hline 6. & $\begin{array}{l}\text { Why did you join the group? } \\
\text { Multiple answers possible }\end{array}$ & $\begin{array}{l}\text { 1. Needed } \\
\text { 2. Peer pressure }\end{array}$ & \\
\hline 7. & $\begin{array}{l}\text { Why did you form a group together? } \\
\text { Multiple answers possible }\end{array}$ & $\begin{array}{l}\text { 1. Similar income } \\
\text { 2. Similar occupation } \\
\text { 3. Same community } \\
\text { 5. Friends } \\
\text { 6. Relatives } \\
\text { 7. Other, specify }\end{array}$ & \\
\hline 8. & What is your position in the group & $\begin{array}{l}\text { 1. Big group leader } \\
\text { 2. Small group leader } \rightarrow \text { GO TO Q12 } \\
\text { 3. Big and small group leader } \\
\text { 4. Normal member } \rightarrow \text { GO TO Q12 }\end{array}$ & \\
\hline 9. & $\begin{array}{l}\text { If you are a big group leader in the previous question, } \\
\text { What are your specific tasks? } \\
\text { Multiple answers possible [OPEN QUESTION] }\end{array}$ & $\begin{array}{ll}\text { 1. Opening group meeting } & \text { 5. Punish if group member did not } \\
\text { 2. Collecting weekly repayments } & \text { paid weekly repayments } \\
\text { 3. Decide if new borrower is } & \begin{array}{l}\text { 6. Kick group members out of } \\
\text { allowed in group }\end{array} \\
\begin{array}{ll}\text { 4. Punish if group member is too } \\
\text { late }\end{array} & \begin{array}{l}\text { 7. Other, specify } \\
\end{array}\end{array}$ & \\
\hline 10. & If you are a big group leader, when did you become the big group leader? & Month - Year & \\
\hline 11. & How were you selected? & $\begin{array}{l}\text { 1. Anonymous election by group } \\
\text { 2. Non-anonymous election by group } \\
\text { 3. Elected by loan officer } \\
\text { 4. Elected by previous group leader } \\
\text { 6. Other, specify }\end{array}$ & \\
\hline
\end{tabular}


12. What are the most important qualifications that a group leader must have?

2. Position in community

3. Good speaker

4. Trustworthy

5. Oldest of the group

Multiple answers possible

[OPEN QUESTION]

13. Has anyone been refused membership by the group?

1. Yes

2. No $\rightarrow \mathrm{GO}$ TO Q15

14. If yes, what's the main reason?

1. There is a limit to group size

2. We don't know her

3. It's difficult to get her approved by BRAC

15. Has anyone been refused membership by BRAC?

4. Other, specify

1. Yes

2. No $\rightarrow \mathrm{GO}$ TO 17

16. If yes, what's the main reason?

1. Did not need any more members

2. Not trustworthy

3. Not similar income

4. We did not know her

17. How many people have left this group?

5. Other, specify

18. How many people have joined in the last year?

19. Do you know if there are people who would like to have a loan of BRAC, but cannot receive a loan?

20. If yes, how many people?

21. Who takes the decisions in the meetings for the following activities?
a) Group positions
b) Loan to members
c) Penalty for non-payment
d) Activities of meeting

22. Do you attend the weekly meetings?

23. How long do you have to walk from your house to the weekly meeting place?

24. How long do you have to walk from your house to the branch?

Amount

Amount

2. No $\rightarrow \mathrm{GO}$ TO Q21

Amount

1. Voting of majority of members

2. Big group leader only

3. Small group leader only

4. Big and small group leaders

5. Loan officer of BRAC

6. Other, specify

1. Always; 2. Often; 3. Sometimes; 4. Never

In minutes

In minutes 


\begin{tabular}{|c|c|c|}
\hline 25. & $\begin{array}{l}\text { How many times (in terms of weeks) have you been unable to repay your } \\
\text { weekly instalments in the last three months? }\end{array}$ & Write down the number of times, e.g. 4 for 4 times, or 0 for 0 times. \\
\hline 26. & $\begin{array}{l}\text { Has one of your PRESENT group members ever been unable to repay the } \\
\text { weekly repayment? }\end{array}$ & $\begin{array}{l}\text { 1. Yes } \\
\text { 2. No } \rightarrow \mathrm{GO} \text { TO Q28 }\end{array}$ \\
\hline 27. & If yes, did you ever pay for her weekly repayment? & $\begin{array}{l}\text { 1. Yes } \\
\text { 2. No }\end{array}$ \\
\hline 28. & $\begin{array}{l}\text { In the history of this group, have group members ever repaid loans for } \\
\text { other members when they were unable to? }\end{array}$ & $\begin{array}{l}\text { 1. Yes } \\
\text { 2. No } \rightarrow \mathrm{GO} \text { TO } 31\end{array}$ \\
\hline 29. & How many times did this happen in your group in a year? & Amount \\
\hline 30. & $\begin{array}{l}\text { Can you remember which of the PRESENT group members were unable to } \\
\text { repay their loans? }\end{array}$ & $\begin{array}{l}\text { Write down the ID numbers of the names } \\
\text { USE PARTICIPANTS LIST }\end{array}$ \\
\hline 31. & How many weekly meetings have you missed in the last three months? & Write down the number of times, e.g. 4 for 4 times, or 0 for 0 times. \\
\hline 32. & Is there a fee for a group member/leader for not attending the meetings? & $\begin{array}{l}\text { 1. Yes } \\
\text { 2. No } \rightarrow G O T O Q 34\end{array}$ \\
\hline 33. & If yes, how much is the fee? & In Leones \\
\hline 34. & $\begin{array}{l}\text { Does the group leader know of the loans that group members have with } \\
\text { BRAC }\end{array}$ & $\begin{array}{l}\text { 1. Yes } \\
\text { 2. No }\end{array}$ \\
\hline 35. & $\begin{array}{l}\text { Do other group members know of the loans that group members have } \\
\text { with BRAC? }\end{array}$ & $\begin{array}{l}\text { 1. Yes } \\
\text { 2. No }\end{array}$ \\
\hline 36. & $\begin{array}{l}\text { Does the group leader know of the loans that group members have with } \\
\text { institutions other than BRAC? }\end{array}$ & $\begin{array}{l}\text { 1. Yes } \\
\text { 2. No }\end{array}$ \\
\hline 37. & $\begin{array}{l}\text { Do other members know of the loans that group members have with } \\
\text { institutions other than BRAC? }\end{array}$ & $\begin{array}{l}\text { 1. Yes } \\
\text { 2. No }\end{array}$ \\
\hline 38. & $\begin{array}{l}\text { Does the group leader know of loans that group members have with other } \\
\text { individuals? }\end{array}$ & $\begin{array}{l}\text { 1. Yes } \\
\text { 2. No }\end{array}$ \\
\hline 39. & $\begin{array}{l}\text { Do other members know of the loans that members have with other } \\
\text { individuals? }\end{array}$ & $\begin{array}{l}\text { 1. Yes } \\
\text { 2. No }\end{array}$ \\
\hline 40. & Who are the group members of your small group? & $\begin{array}{l}\text { Give ID of the persons } \\
\text { USE PARTICIPANTS LIST } \\
\text { ONLY GIVE THE NAMES OF THE OTHER GROUP MEMBERS, NOT THE ID } \\
\text { OF THE PERSON YOU ARE INTERVIEWING! }\end{array}$ \\
\hline
\end{tabular}




\subsection{Network}

ASK THE PARTICIPANT THE QUESTIONS, E.G. WITH WHOM ARE YOU FRIENDS?, THEN GIVE AN 'X' IN THE BOX FOR THE ID OF THE NAME GIVEN BY THE RESPONDENT

\begin{tabular}{|c|c|c|c|c|c|c|}
\hline ID & $\begin{array}{l}1 . \quad \text { With } \\
\text { whom are } \\
\text { you friends? }\end{array}$ & $\begin{array}{l}\text { 2. With whom } \\
\text { are you blood } \\
\text { family? }\end{array}$ & $\begin{array}{l}\text { 3. To whom do } \\
\text { you lent } \\
\text { money? }\end{array}$ & $\begin{array}{l}\text { 4. With whom do you } \\
\text { meet outside the } \\
\text { BRAC meeting? }\end{array}$ & $\begin{array}{l}\text { 5. With whom } \\
\text { do you do } \\
\text { business? }\end{array}$ & $\begin{array}{l}\text { 6. With whom do you } \\
\text { go to the same } \\
\text { mosque/church? }\end{array}$ \\
\hline & Tally & Tally & Tally & Tally & Tally & Tally \\
\hline \multicolumn{7}{|l|}{1.} \\
\hline \multicolumn{7}{|l|}{2.} \\
\hline \multicolumn{7}{|l|}{3.} \\
\hline \multicolumn{7}{|l|}{4.} \\
\hline \multicolumn{7}{|l|}{5.} \\
\hline \multicolumn{7}{|l|}{6.} \\
\hline \multicolumn{7}{|l|}{7.} \\
\hline \multicolumn{7}{|l|}{8.} \\
\hline \multicolumn{7}{|l|}{9.} \\
\hline \multicolumn{7}{|l|}{10.} \\
\hline \multicolumn{7}{|l|}{11.} \\
\hline \multicolumn{7}{|l|}{12.} \\
\hline \multicolumn{7}{|l|}{13.} \\
\hline \multicolumn{7}{|l|}{14.} \\
\hline \multicolumn{7}{|l|}{15.} \\
\hline \multicolumn{7}{|l|}{16.} \\
\hline \multicolumn{7}{|l|}{17.} \\
\hline \multicolumn{7}{|l|}{18.} \\
\hline \multirow{2}{*}{\multicolumn{7}{|c|}{$\frac{19 .}{20 .}$}} \\
\hline \multicolumn{4}{|l|}{20.} & & & \\
\hline 21. & & & & & & \\
\hline 22. & & & & & & \\
\hline 23. & & & & & & \\
\hline 24. & & & & & & \\
\hline 25. & & & & & & \\
\hline 26. & & & & & & \\
\hline 27. & & & & & & \\
\hline 28. & & & & & & \\
\hline 29. & & & & & & \\
\hline 30. & & & & & & \\
\hline 31. & & & & & & \\
\hline 32. & & & & & & \\
\hline 33. & & & & & & \\
\hline 34. & & & & & & \\
\hline 35. & & & & & & \\
\hline 36. & & & & & & \\
\hline 37. & & & & & & \\
\hline 38. & & & & & & \\
\hline 39. & & & & & & \\
\hline 40. & & & & & & \\
\hline 41. & & & & & & \\
\hline 42. & & & & & & \\
\hline 43. & & & & & & \\
\hline 44. & & & & & & \\
\hline 45. & & & & & & \\
\hline 46. & & & & & & \\
\hline 47. & & & & & & \\
\hline 48. & & & & & & \\
\hline 49. & & & & & & \\
\hline 50. & & & & & & \\
\hline
\end{tabular}


Individual Record Sheet

\begin{tabular}{|c|c|c|}
\hline Branch & Code & \\
\hline Group & Code & \\
\hline Member & Code & \\
\hline Loan Officer & Code & \\
\hline Enumerator & Code & \\
\hline RA Team code & Date & $I_{-} \perp_{-}$ \\
\hline
\end{tabular}

\section{Activity \#1 Coordination Game BIG GROUP}

\begin{tabular}{|c|c|c|c|c|}
\hline \multicolumn{3}{|c|}{$\begin{array}{l}\text { If you had to guess what most people in your group think, guess which answer people give most } \\
\text { often to these questions. }\end{array}$} & \multirow{2}{*}{ Winner? } & \multirow{2}{*}{$\begin{array}{l}\text { Payout } \\
\text { to HH }\end{array}$} \\
\hline $\begin{array}{l}\text { Enumerator says: "Who would most people } \\
\text { in the group think is": }\end{array}$ & Name & ID & & \\
\hline $\begin{array}{l}\text { 1. The new group leader, if a new group leader } \\
\text { has to be chosen }\end{array}$ & & & $\begin{array}{ll}\mathrm{N} \\
\mathrm{N}\end{array}$ & \\
\hline 2. Most likely to show up early in a meeting & & & $\begin{array}{ll}\mathrm{N} \\
\mathrm{N}\end{array}$ & \\
\hline 3. The best dressed of the group & & & Y N & \\
\hline 4 The best singer of the group & & & Y N & \\
\hline
\end{tabular}

\section{Activity \#2 Public Good Game}

SMALL GROUP

\begin{tabular}{|c|c|c|c|c|}
\hline $\begin{array}{l}\text { I am going to give you and your SMALL group } \\
\text { members } 2.000 \text { Le. We ask every member individually } \\
\text { how much of the } 2.000 \text { Le they want to put in a public } \\
\text { pot. }\end{array}$ & $\begin{array}{l}\text {-1- } \\
\text { Amount kept } \\
\text { for theirselves } \\
\text { FILL IN }\end{array}$ & $\begin{array}{l}\text {-2- } \\
\text { Amount put in } \\
\text { the public pot } \\
\text { FILL IN }\end{array}$ & $\begin{array}{l}\text {-3- } \\
\text { Amount returned } \\
\text { from the put }\end{array}$ & $\begin{array}{l}\text { Total amount } \\
\text { received } \\
(1+3)\end{array}$ \\
\hline $\begin{array}{l}\text { The total amount of the public pot will get tripled and } \\
\text { equally divided. The amount you will receive is how } \\
\text { much you kept, plus whatever you get returned from } \\
\text { the public pot. }\end{array}$ & Le & Le & Le & Le \\
\hline
\end{tabular}

\section{BIG GROUP}

\begin{tabular}{|c|c|c|c|c|}
\hline $\begin{array}{l}\text { I am going to give you and your BIG group members } \\
2.000 \text { Le. We ask every member individually how much } \\
\text { of the } 2.000 \text { Le they want to put in a public pot. } \\
\text { The total amount of the public pot will get tripled and }\end{array}$ & $\begin{array}{l}\text {-1- } \\
\text { Amount kept } \\
\text { for theirselves } \\
\text { FILL IN } \\
\end{array}$ & $\begin{array}{l}\text {-2- } \\
\text { Amount put in } \\
\text { the public pot } \\
\text { FILL IN }\end{array}$ & $\begin{array}{l}\text {-3- } \\
\text { Amount returned } \\
\text { from the put }\end{array}$ & $\begin{array}{l}\text { Total amount } \\
\text { received } \\
(1+3)\end{array}$ \\
\hline $\begin{array}{l}\text { equally divided. The amount you will receive is how } \\
\text { much you kept, plus whatever you get returned from } \\
\text { the public pot. }\end{array}$ & Le & Le & Le & Le \\
\hline
\end{tabular}

\section{Activity \#3 Dictator Game SMALL GROUP}

I am giving you 3.000 Le. For each
person that I ask you about, it is a
new 3.000 Le. The money is yours;
you can share some, share none, or
share all. There is no obligation to
share, it is only what you want to do.
The receiver will not know who the
money was sent by

\begin{tabular}{|c|c|c|c|c|c|c|}
\hline ID & ID & ID & ID_ & ID_ & ID GL__ & ID LO_ \\
\hline Le & Le & Le & Le & Le & Le & Le \\
\hline
\end{tabular}


Coordination Game Record Sheet

\begin{tabular}{|c|c|c|}
\hline Branch & Code & \\
\hline Group & Code & \\
\hline Loan Officer & Code & \\
\hline Enumerator & Code & \\
\hline RA Team code & Date & $1_{-1} 1_{-}$ \\
\hline
\end{tabular}

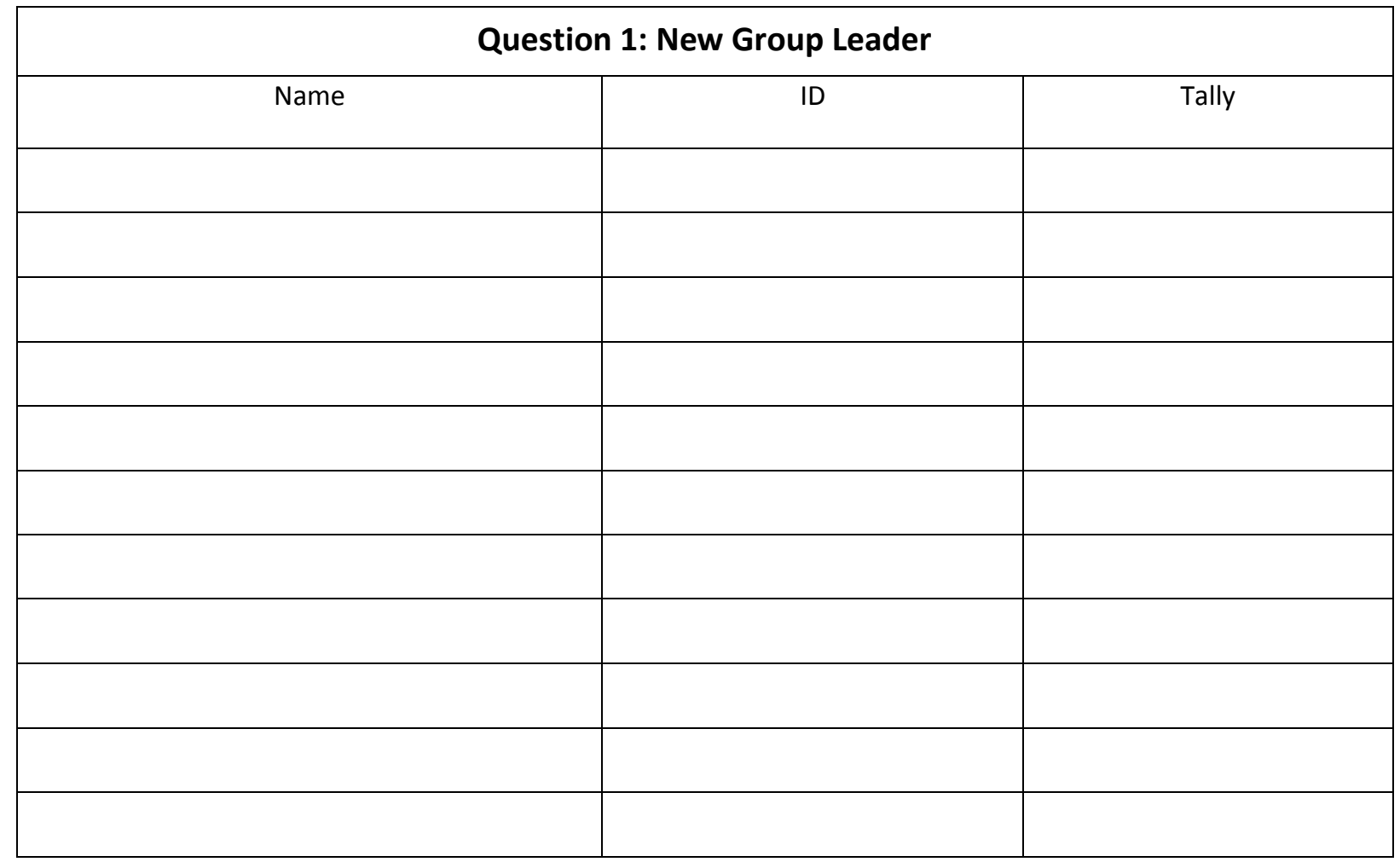

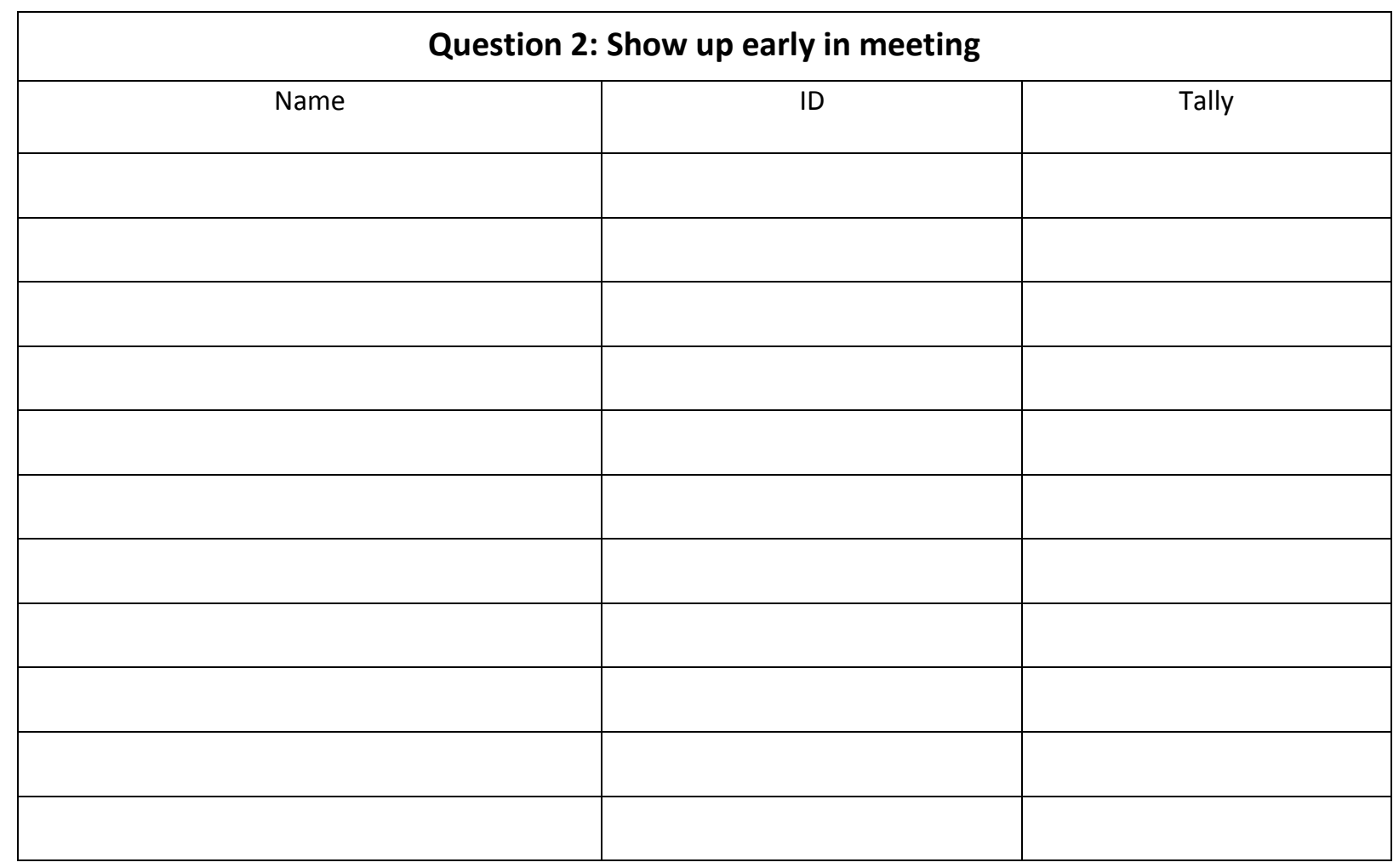




\begin{tabular}{|c|c|c|}
\hline \multicolumn{3}{|c|}{ Question 3: Best Dressed } \\
\hline Name & II & Tally \\
\hline & & \\
\hline & & \\
\hline & & \\
\hline & & \\
\hline & & \\
\hline & & \\
\hline & & \\
\hline & & \\
\hline & & \\
\hline & & \\
\hline & & \\
\hline & & \\
\hline
\end{tabular}

\begin{tabular}{|c|c|c|}
\hline \multicolumn{3}{|c|}{ Question 4: Best Singer } \\
\hline Name & ID & Tally \\
\hline & & \\
\hline & & \\
\hline & & \\
\hline & & \\
\hline & & \\
\hline & & \\
\hline & & \\
\hline & & \\
\hline & & \\
\hline & & \\
\hline & & \\
\hline & & \\
\hline
\end{tabular}




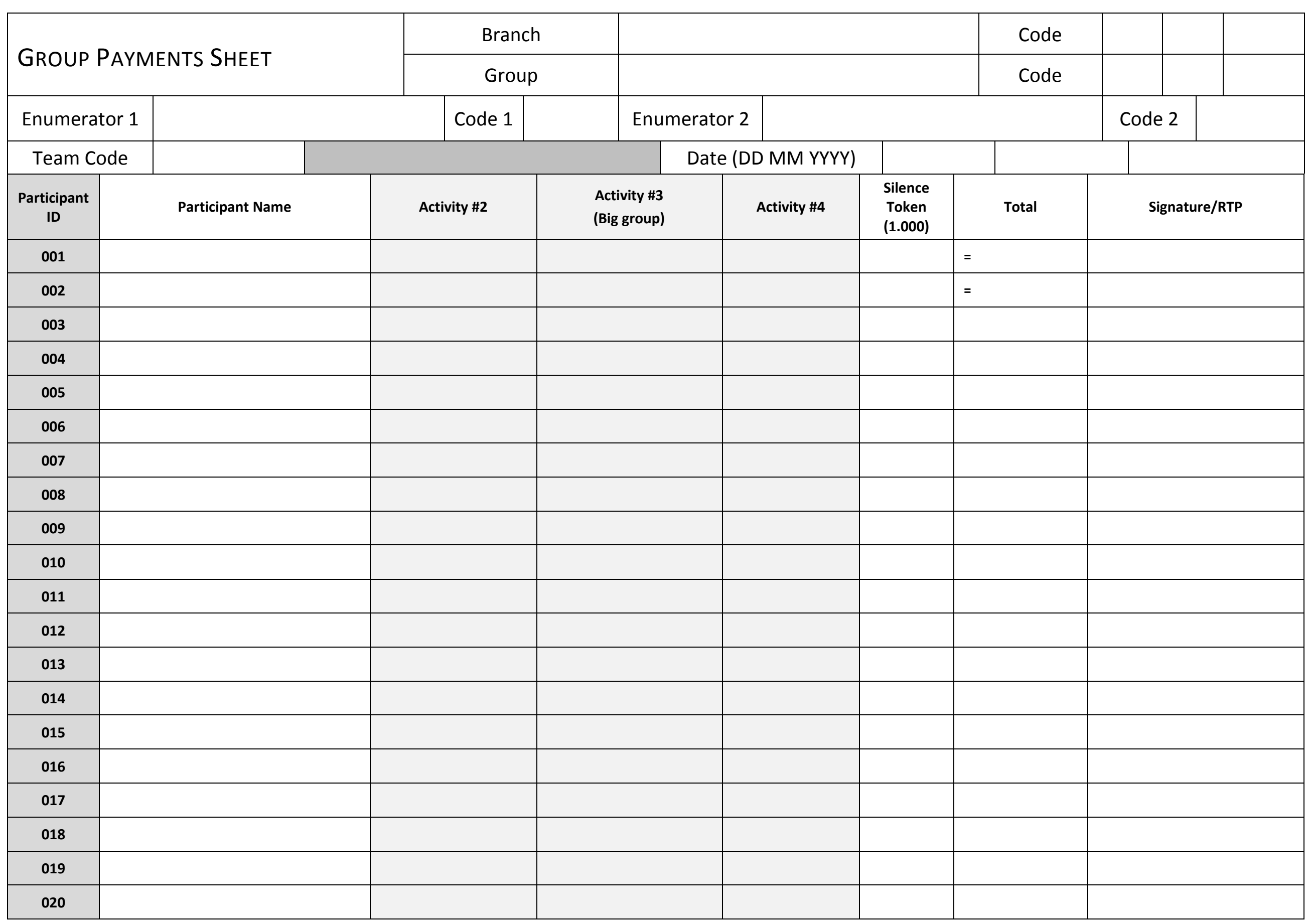




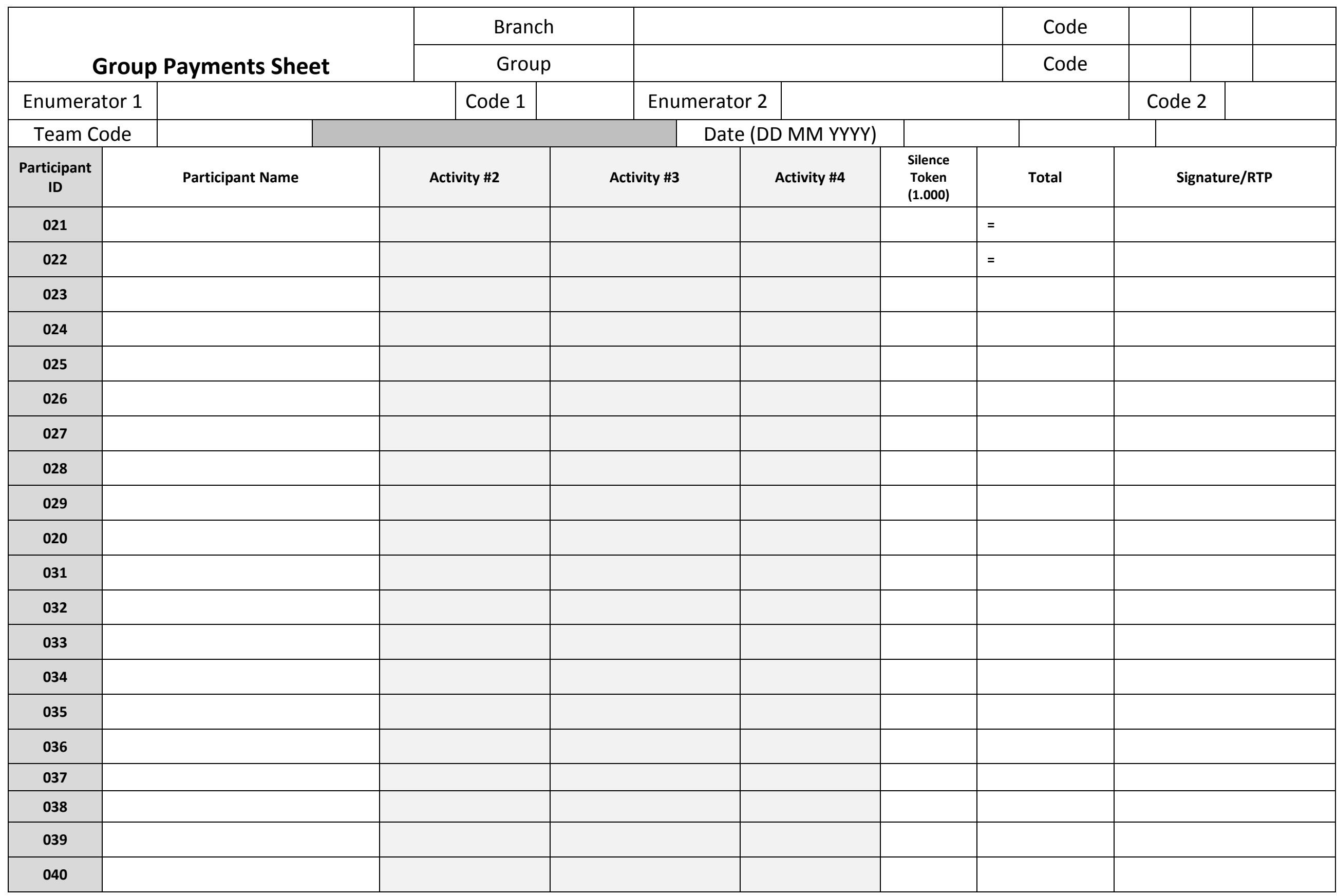


Appendix D. PROTOCOLS 


\section{EVALUATION MF SL BRAC - PROTOCOLS}

\section{Wageningen University/BRAC Sierra Leone}

Version: 08-03-2014

\section{CONTENTS}

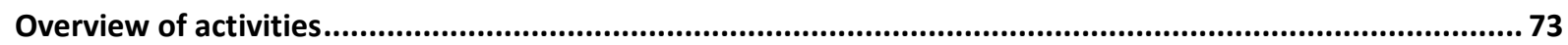

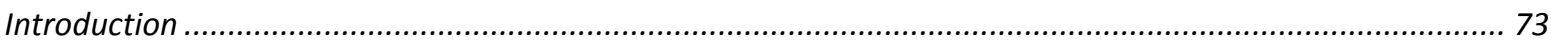

Phase 1: Group composition study .......................................................................................................... 73

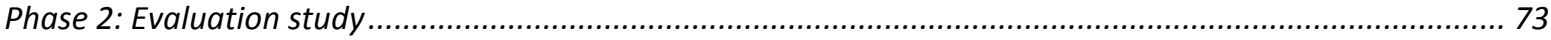

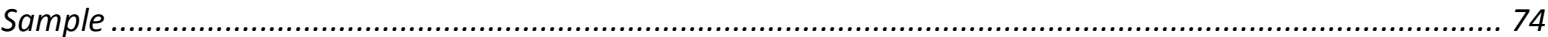

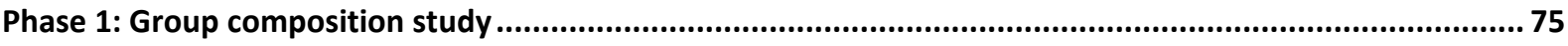

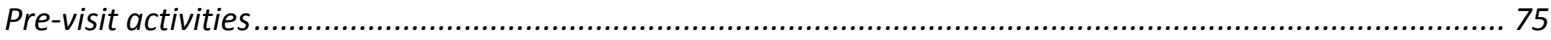

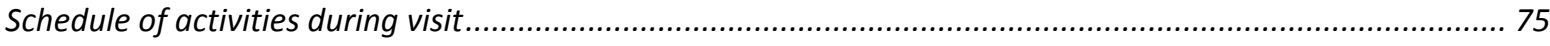

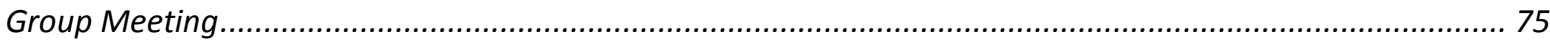

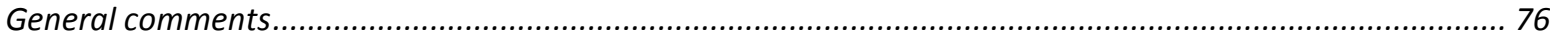

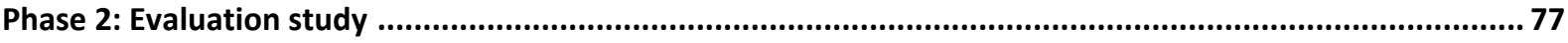

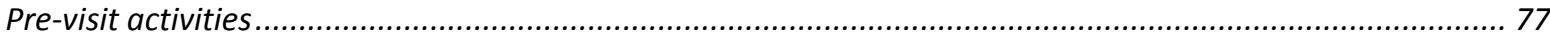

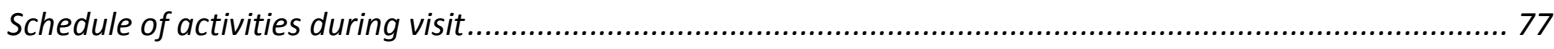

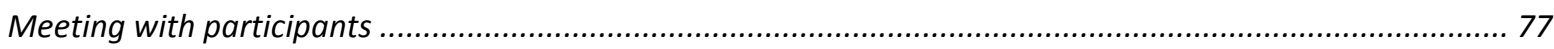

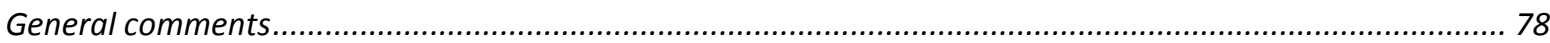




\section{Overview of activities}

\section{Introduction}

In this document we outline the main activities to be undertaken in Sierra Leone starting from January 2014. The objective of this survey is to assess (i) the determinants of clients, (ii) whether clients improve their wellbeing, and are less vulnerable and (iii) whether clients are satisfied with the services provided by BRAC and (iv) to understand the processes underlying the composition of the groups and the influence of group composition on financial behaviour. This document includes the instrument used when conducting the survey.

\section{PHASE 1: GROUP COMPOSITION STUDY}

The group composition study consists of several parts (PART 1 and PART 2 OF SURVEY);

\section{Group member ( $\&$ group leader) survey}

This survey will include questions on the bigger group level, such as how long a group exists, composition of group, questions on the smaller group level, also how long a group exists, composition of group, questions about individual borrowers and their loan outcomes. But also questions about the characteristics of a group leader, how long a group leader is positioned, what her tasks are.

\section{Loan officer survey}

The survey will include questions about the characteristics of the loan officer, what her tasks are, how long she is positioned.

\section{Coordination game}

The coordination game is a measure of social closeness and coordination within a group. This game is meant to understand how much the group members know the other group members. The enumerator explains that when answering this question person A has to think about what most people in the group would answer. So for example; "Which group member dresses the best?" Then person $\mathrm{A}$ has to give the name of the person she thinks most people would answer. When she guesses right, she can win 500 Leones, when she guesses wrong, she wins nothing. This game will be played in the big group, and later when analysing the data we will check for any outcomes on the small group level.

\section{Network analysis}

To understand the possible intertwined relationships in groups, we do a network analysis where we ask the borrowers for example who of the other borrowers are family, or are friends. We conduct this network analysis with group members, group leaders and the loan officers.

\section{Public good game}

A public good game gives us an indication of 'free-riding' in a group. We will expect that the higher the cohesion in a group (which is measured with the coordination game and the network survey), the less people will free ride. We will play this game on the small group level and on the big group level.

The game will go as follows: Everyone gets 1000 Leones, we ask them to give a certain amount (can be all, can be nothing) to a public good (a pot which gets divided over the group members), this amount gets tripled and then goes to the public good. This public good (the pot) then gets divided over the amount of people playing the game. This amount can maximum be 3500 Leones in the small group and 4000 Leones in the big group. Everyone then receives: their share of the pot + amount of Leones they kept of the small group.

\section{Dictator game}

A dictator game is designed to capture benevolence of big group leader/small group leader/loan officer to the group members. Therefore we will play the benevolence game with all 5 small groups with big leader and loan officer.

The idea is to ask every small group member how much of 2500 they want to give to their other group members, to the big group leader and to the loan officer. We will ask this for every member of every 
small group. Then we will ask the big group leader how much they want to give of 2500 Leones to every other group member (so 29 people) and the loan officer. Then we will ask the loan officer how much they want to give to all group members (30 people) and the big group leader. Everything is anonymous: no one knows who the person is who is giving them a certain amount.

\section{Phase}

2:

Evaluation

study

An individual survey will be conducted in eight branches and will be divided in four groups per branch. The survey includes a range of questions capturing household identification, socio-demographics, income, housing, health, food security, consumption, client satisfaction and risk behaviour (PART 1 OF SURVEY).

This is the same survey used in Phase 1.

\section{Sample}

Phase 1 will only be conducted in Mile-91, and will have a total of \pm 700 respondents.

- 600 group members (old and new members)

- 50 non-members inside the boundary of Mile-91

- 50 non-members outside the boundary of Mile-91

Phase 2 will be conducted in 8 branches and will have 1600 respondents in total. Per branch we will have 200 respondents:

- 50 old group members

- 50 new group members

- 50 non-members inside the boundary of the branch

- 50 non-members outside the boundary of the branch 


\section{PHASE 1: GROUP COMPOSITION STUDY}

\section{PRE-VISIT ACTIVITIES}

Before the research activities can start, go to the branch and announce:

- We would like to conduct a survey in your branch. Hand the Branch Manager the Letter of Participation- Branch.

- Several groups are randomly selected. Ask the Branch Manager and Loan Officers to check whether the Participants List is complete, or whether people are now out of the program, or maybe new people have entered the program.

- Tell the Loan Officer that it is very important that everyone on the Participants List is present on the day of the visit.

- Have the Loan Officer read the Letter of Participation - Groups to the selected groups one week before the research team visits.

\section{SCHEDULE OF ACTIVITIES DURING VISIT}

After arrival in the branch, the team leader will present his team to the branch manager. After the acquaintance, start the schedule.

1. Group meeting

2. Research Activities
a. Loan Officer survey (done by the team leader)
b. Group Leader survey (done by the team leader)
c. Group Member survey (all research assistants and the team leader when he/she is done with the Loan Officer/Group Leader survey)
d. Coordination Game
e. Network Analysis
f. Public Goods Game
g. Dictator Game

3. Calculation of earnings

4. Handing out of pay-slips. After the schedule has been completed, the night can be spent in Mile-91.

\section{GROUP MEETING}

1. Convene a meeting and announce:

- Introduce yourself; first as representative of Wageningen University, BRAC Sierra Leone and Njala University, second as yourself, hence your name. Tell them you are Wageningen University researchers, working for BRAC Sierra Leone.

- We would like to conduct some survey activities with all group members, the group leader and the loan officer. BRAC Sierra Leone will not know the names, all is anonymous.

- Tell them you would like to ask them questions and engage in some activities in which they can win some money based on their choices in the activities.

- This money will paid out, after we visited all the groups which are scheduled on that day, by our research supervisor.

- We would like to talk to you each individually. It may take us some time to talk to all of you. We ask you to please be patient.

- Since we can't talk to everyone at once, we ask that you wait before you have taken your turn.

- After you have had your turn, you are welcome to go do other work until all participants have been surveyed. Then we will calculate the amounts earned by all participants. After this is calculated you will receive your pay-slip, which you can cash in with our research supervisor that same day.

- While you wait for your turn in this area, we ask you not to talk to those who have already talked to us. If we overhear you discussing the survey questions or games then we will take away your silence token and you will not earn the additional Le 1,000. 
After announcements;

- Welcome all participants again

- Make sure the Participants List is complete

- $\quad$ Give all participants their ID numbers (Tape+markers)

- Divide up the participants on the Participants List among all the research assistants

- Each research assistant should find a private place and call their first participant to interview (for the team leader this will be the Loan Officer and the Group Leader)

- $\quad$ For the Loan Officer: ask the participant the survey questions on the Loan Officer Survey and Record Sheets. See protocol for survey and activity \#1 - \#4 below.

- $\quad$ For the Group Leader: ask the participant the survey questions on the Group Leader Survey and Record Sheets. See protocol for survey and activity \#1 - \#4 below.

- For the Group Member: ask the participant the survey questions on the Group Member Survey and Record Sheets. See protocol for survey and activity \#1 - \#4 below.

- Conduct the survey and activities and use the form to record their answer and choices. Write neat and clear.

- At the end, tell the participant:

- Thank you for your time today

- We will add up everything you won and write a pay-slip for you. Keep this pay-slip at a safe place. After all participants have been surveyed, our research supervisor will come to make the pay-out.

- Please do not talk to those who have not yet had their interview. If you do, and we catch you, you will not get your 1.000 Leones silence token.

- Do you have any questions?

- Make sure the participants Survey and Record Sheets are completely filled out.

- Put it in a safe place where all of the forms are stored during the day.

- Call your next participant and repeat the interview procedures.

\section{GENERAL COMMENTS}

1. Make sure that you divide the tasks clearly among the different members of the group, so everybody knows where he or she is responsible for. Not only the bigger tasks (paperwork, material, money), but also tasks as who is responsible for the final payment, for writing the receipts etcetera. But if for example the material/stationery person is not around/still busy, make sure that you take care of the stationery for him/her.

2. Think ahead: when you don't have anything to do, already think about what you can do next. For example, writing names and villages on sheets. 


\section{PhASE 2: EVAluATion STUdY}

\section{PRE-VISIT ACTIVITIES}

Before the research activities can start, go to the branch and announce:

- We would like to conduct a survey in your branch. Hand the Branch Manager the Letter of Participation - Branch.

- Several groups are randomly selected. Ask the Branch Manager and Loan Officers to check whether the Participants List is complete, or whether people are now out of the program, or maybe new people have entered the program.

- Tell the Loan Officer that it is very important that everyone on the Participants List is present on the day of the visit.

- Have the Loan Officer read the Letter of Participation - Members to the selected members one week before the research team visits. To have them gather the next week at the stated time and place.

\section{SCHEDULE OF ACTIVITIES DURING VISIT}

After arrival in the branch, the team leader will present his team to the branch manager. After the acquaintance, start the schedule.

1. Meeting with participant

2. Research Activities
a. Group Member survey
b. Non-member survey inside boundary
c. Non-member survey outside boundary

3. After the schedule has been completed, the night can be spent in the city or village where the branch is located.

\section{MEETING WITH PARTICIPANTS}

2. Convene a meeting and announce:

- Introduce yourself; first as representative of Wageningen University, BRAC Sierra Leone and Njala University, second as yourself, hence your name. Tell them you are Wageningen University researchers, working for BRAC Sierra Leone.

- We would like to conduct some survey activities with all participants, i.e. you would like to ask them some questions. BRAC Sierra Leone will not know the names, all is anonymous.

- We would like to talk to you each individually. It may take us some time to talk to all of you. We ask you to please be patient.

- Since we can't talk to everyone at once, we ask that you wait before you have taken your turn.

- After you have had your turn, you are welcome to go.

- While you wait for your turn in this area, we ask you not to talk to those who have already talked to us.

After announcements;

- Welcome all participants again

- Make sure the Participants List is complete

- Give all participants their ID numbers (Tape+markers)

- Divide up the participants on the Participants List among all the research assistants

- Each research assistant should find a private place and call their first participant to interview (for the team leader this will be the Loan Officer and the Group Leader)

- For the Group Member: ask the participant the survey questions on the Group Member Survey. See protocol for survey below.

- For the Non-Member: ask the participant the survey questions on the Non-Member Survey. See protocol for survey below.

- Conduct the survey and use the form to record their answer and choices. Write neat and clear. 
- $\quad$ At the end, tell the participant:

- Thank you for your time today

- Please do not talk to those who have not yet had their interview

- Do you have any questions?

- Make sure the participants Survey are completely filled out.

- Put it in a safe place where all of the forms are stored during the day.

- Call your next participant and repeat the interview procedures.

\section{GENERAL COMMENTS}

3. Make sure that you divide the tasks clearly among the different members of the group, so everybody knows where he or she is responsible for. Not only the bigger tasks (paperwork, material, money), but also tasks as who is responsible for the final payment, for writing the receipts etcetera. But if for example the material/stationery person is not around/still busy, make sure that you take care of the stationery for him/her.

4. Think ahead: when you don't have anything to do, already think about what you can do next. For example, writing names and villages on sheets. 


\section{RESPONDENT SURVEY PART 1}

1. Tell the participant:

- My name is . We are here to collect information about BRAC's microfinance services and their clients, for a study of BRAC Sierra Leone, Njala University and a university in the Netherlands. Your branch was selected to be part of this survey.

- The researchers will keep your responses confidential. Your full name will never be used anywhere to ensure confidentiality.

- You are not obliged to answer questions if you do not want to and you are free to stop the interview at all times.

- We hope that the research will benefit Sierra Leone by assisting us to understand BRAC's microfinance services and maybe even improve these in the future.

- Do you have any questions for me? You may ask questions about this study at any time

- The survey will take approximately half an hour.

2. Hand over the informed consent sheet and review the Informed Consent form. Emphasize that:

- $\quad$ No one has to participate.

- There will be no negative consequences to anyone if you do not want to participate.

- Everything you do with us will be confidential. We will not tell anyone in your group what you tell us. When we record your information, we will not include your name with your file so that anyone can come back and say anything to you about what you tell us. Everything we record today will be kept in a safe location in Europe.

3. Ask each question and record their answers in the appropriate boxes.

4. If you are part of the PHASE I study, you continue with the protocol

5. If you are part of the PHASE II study, you stop here.

- Tell the participant:

- Thank you for your great patience and cooperation. We have enjoyed working with you.

- Look up your next participant and start all over again.

\section{RESPONDENT SURVEY PART 2}

1. Tell the participant that the first part of the survey has been completed, and that we are now starting with the second part.

2. This part includes questions and activities where a small amount of Leones can be earned, based on their decisions in the activity.

3. Tell the participant that this will be explained later on in the survey.

4. Ask each question and perform each activity and record their answers in the appropriate boxes.

\section{NETWORK ANALYSIS}

1. Tell the participant:

- We will be asking everyone that we survey the same questions.

- We will say the name of your group member and then ask 6 questions regarding the relationship of this group member with you.

- Give the name of the first ID.

- Then ask the participant:

- Are you friends with this person?

- Are you blood family with this person?

- Have you lent money to this person?

- How many times per week do you meet outside of the BRAC meeting?

- Do you do business with this person?

- Do you go to the same church/mosque as this person?

- Repeat for all IDs (including group leader and loan officer)

\section{ACTIVITY \#1: COORDINATION GAME}


1. Tell the participant:

- We will be asking everyone that we survey these same questions.

- When thinking of the answer you want to give, try to guess the name of the person you think most people in your big group will say for each of these questions.

- You will win 500 Le for every time you give the same answer that is most often given.

- For example, if we asked you the question, "What is the best Sierra Leonean dish?" and 10 people said groundnut soup and 5 people said potato leaves, then if you were one of those who said groundnut soup you would win 500 Le but if you were one of those that said potato leaves you would not win anything.

- You may answer "No one" or "None", but those types of answers cannot win, so you should do your best to pick a specific person's name (e.g. slightly agree or neither agree or disagree).

1. Make sure that they give you the right name and spelling. Names are often quite similar. Also fill the person's ID in the sheet.

2. For questions 1 through 4, read the below prompt to the participant:

- If you had to guess what most people in your big group think, who do you think they would say is:

- If a new group leader is needed, who would be the most likely to be chosen

- Who is most likely to show up early in a meeting

- Who is the best dressed of the group

Who is the best singer of the group

3. Make sure that you do NOT ask what the interviewee thinks is the best cook in the big group, but what MOST OF THE GROUP MEMBERS think is the best cook in the big group.

4. Record the full name of their response or the appropriate code for their response.

\section{Activity \#2: Public GoOd GAME}

1. Tell the participant:

- We are going to play a game, we will play this game with all the participants.

- There are two rounds in this game; the first round is with the members of your small group. The second round is with the members of the big group.

2. Tell the participant: We will begin with the first round;

- I am going to give you and your group members 2.000 Le. Then we will ask every member individually how much of the 2.000 Le they want to put in a public pot.

- There is no obligation to put something in the public pot, it is only what you want to put in the public pot.

- The total amount of the public pot will then get tripled and equally divided over the members of the group, no matter how much someone has put in the pot.

- The amount you will receive at the end of the game is how much you kept, so the amount you did not put in the public pot, plus whatever you get returned from the public pot.

3. Ask the participant: How much do you want to put in the public pot?

4. Tell the participant: Now we will play the second round of the game.

- $\quad$ This time we will play the game with the members of the big group.

- You are getting the same amount of Leones; 2.000 Le.

- And you are asked again how much you want to put in the public pot.

- The amount you will receive at the end of the game is the amount you kept and the amount you get returned from the public pot.

5. Ask the participant: How much do you want to put in the public pot?

\section{ACTIVITY \#3: DICTATOR GAME}

1. Tell the partipant:

- I am giving you 2.500 Le

- For each person that I will ask you about, it is a new 2.500 Le

- The money is yours; you can share some, share none, or share it all 
- There is no obligation to share; it is only what you want to share

- The receiver will not know who the money was sent by

\section{PAY-SLIP PAYMENT}

1. When everyone has finished the survey and activities, tell the participants:

- Thank you for your great patience and cooperation. We have enjoyed working with you.

2. Calculate the winning answers for the coordination game on the Coordination Game Record Sheet and mark which questions people got correct on their Loan Officer Survey and Record Sheets, Group Leader Survey and Record Sheets and Group Member Survey and Record Sheets.

3. Use the Loan Officer Survey and Record Sheets, Group Leader Survey and Record Sheets and Group Member Survey and Record Sheets to calculate the total amount of money owed to each participant in each of the games.

4. Record these amounts on the Group Payment Sheet. (This should be done by the same person always!)

5. Record on the Group Payment Sheet how much the two public pots in Activity \#3 is, triple the amount of the public pot of the big group and divide it over the amount of people in the group. Write the amount on the Group Payment Sheet. Remember: the first public pot is played with the small group and the second public pot is played with the big group. (The Loan Officer only plays Activity \#3 with the big group).

6. Record on the Group Payment Sheet how much each participant is owed based on his or her matched participant in Activity \#4. Remember: For all households you just add up one to come to the matched participants. So participant \#2 shares with participant \#3, participant \#3 shared with participant \#4, etc. The last participant shares with participant \#1. And the group leader shares with the loan officer, and the loan officer with the group leader.

7. Add a bonus of 1.000 Le on the Group Payment Sheet if the participant kept their silence token.

8. Calculate the total amount owed to the participant.

9. Wait for Karen to come to the group to pay-out the participants.

10. Ask the first person in the line to come into the private place to get their payment

11. Have them give a thumbprint in the 'received' column, certifying they received their payment.

12. Send the participant out of the private room, and repeat this process with all remaining participants.

13. Only in very special occasions: If a participant cannot wait for Karen, make a pay-slip, with the date and location and A STAMP. 